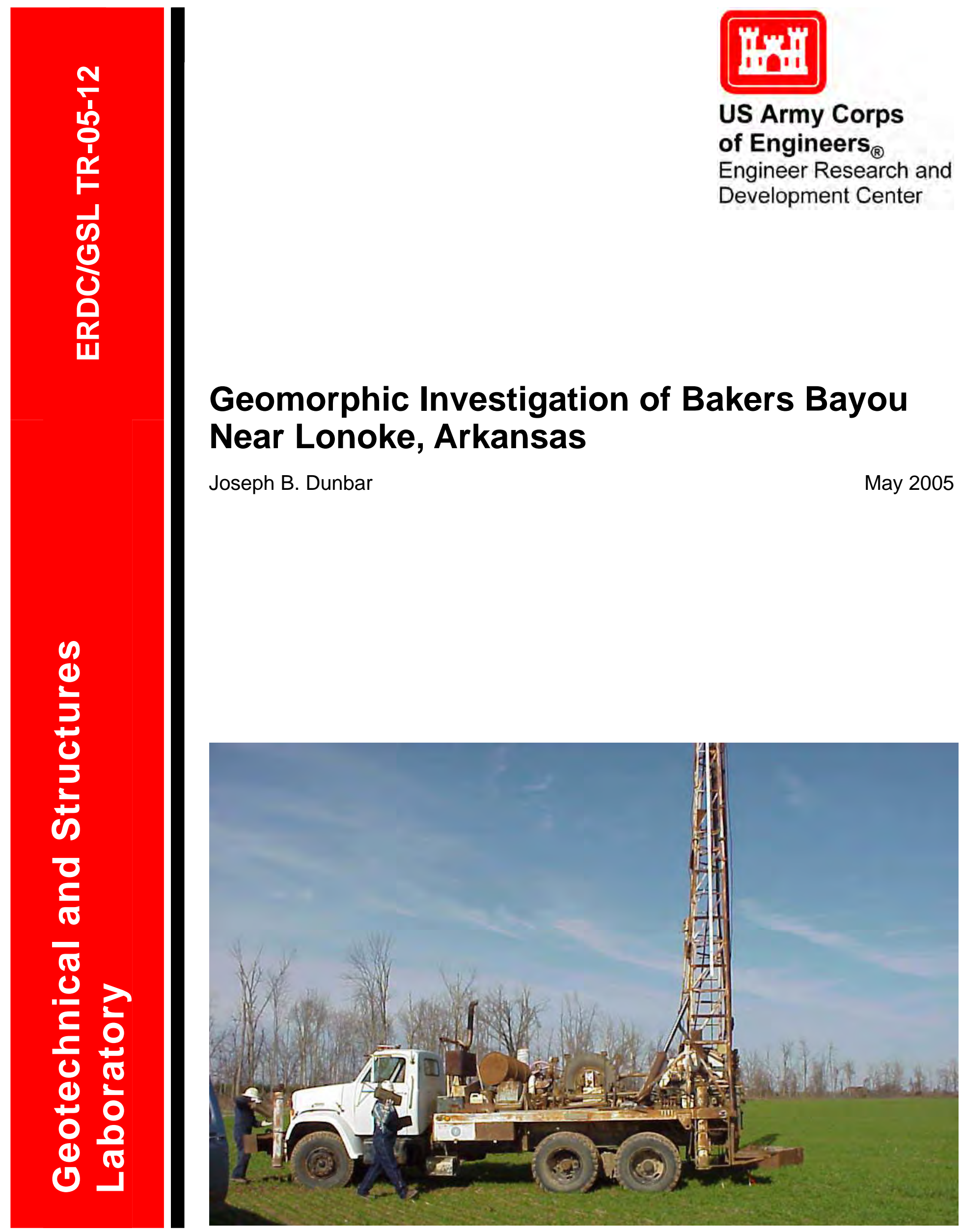




\section{Geomorphic Investigation of Bakers Bayou Near Lonoke, Arkansas}

Joseph B. Dunbar

Geotechnical and Structures Laboratory

U.S. Army Engineer Research and Development Center

3909 Halls Ferry Road

Vicksburg, MS 39180-6199

Final report

Approved for public release; distribution is unlimited 


\begin{abstract}
This report documents a geomorphic study of a 5-km reach of Bakers Bayou, near Lonoke, AR. The purpose of the study was to determine the historic limits of the channel fill and the width of the prehistoric bayou, a former Arkansas River course. An integrated study was conducted involving historic data, geomorphology, soil stratigraphy, geophysics, and radiometric dating methods. Results of the study indicate that the area evaluated was an active Arkansas River course between 6,000 and 8,000 years before the present, and the maximum channel width was between 600 and $900 \mathrm{ft}$. The channel by 1850 at the area studied was between 66 and $231 \mathrm{ft}$ wide and was tree filled with shallow standing water and no clear-cut main channel.
\end{abstract}

DISCLAIMER: The contents of this report are not to be used for advertising, publication, or promotional purposes. Citation of trade names does not constitute an official endorsement or approval of the use of such commercial products. All product names and trademarks cited are the property of their respective owners. The findings of this report are not to be construed as an official Department of the Army position unless so designated by other authorized documents. 


\section{Contents}

1-Introduction

2-Methods.....................................................................................

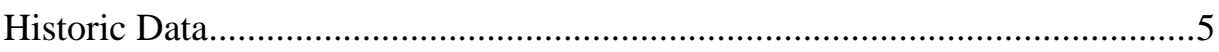

Aerial Photo Interpretation ......................................................................6

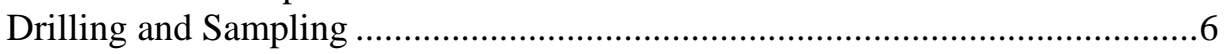

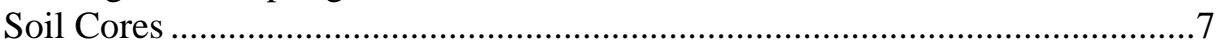

Radiometric Dating of Soil Samples ..........................................................

Topographic Profiles .................................................................................10

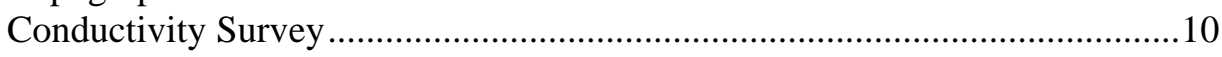

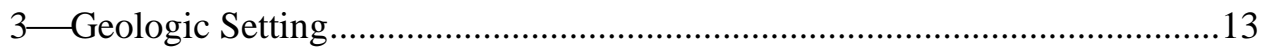

Arkansas River Courses and Meander Belts ...................................................13

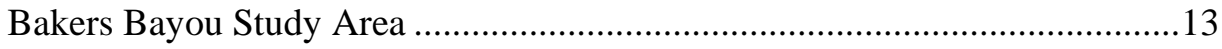

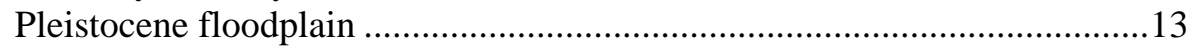

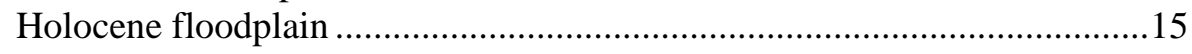

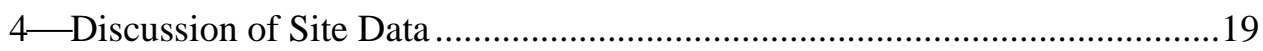

Width of Abandoned Course at Site 6 .........................................................19

Historic Limits Based on Site Surveys and Maps .........................................19

Historic Limits Based on Photos and Imagery .............................................20

Selected 1854 GLO Survey Locations ......................................................26

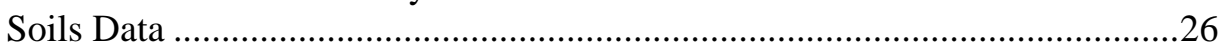

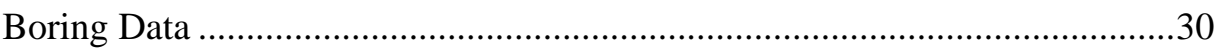

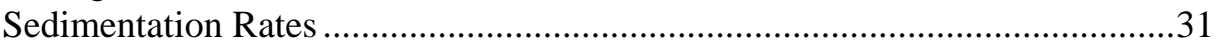

Buried Keo and Perry Soils as Historic Marker Horizons................................33

5-Conclusions and Recommendations ..........................................................34

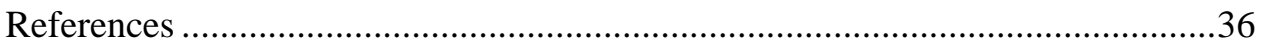

Plate 1

Appendix A: Soil Boring Logs................................................................... A1 
Appendix B: Cesium-137 and Lead-210 Dating Results

Appendix C: Carbon-14 Dating Results.....

Appendix D: Topographic Profiles Across Bakers Bayou.

Appendix E: USDA Soil Profile Information

\section{List of Figures}

Figure 1. Location map of Bakers Bayou showing 9 January 2001 field trip stops. Site 6 is the focus of the current geomorphic study ..........2

Figure 2. View across Bakers Bayou at Site 6. Trees in the middle of the photograph correspond to the approximate center of the old Arkansas River course at this location

Figure 3. View across Bakers Bayou at Site 3 (see Figure 1 for photo location)

Figure 4. Geomorphic map of the Bakers Bayou study area showing major fluvial landforms

Figure 5. Location of borings drilled as part of this study (red circles), topographic profiles (blue line), referenced cone penetrometer boring (blue circle), and conductivity survey (same as profile locations, blue line).

Figure 6. Drilling equipment used to sample at Bakers Bayou, Site 6. Drill rig is set up within the old channel of the abandoned Arkansas River Course. Tree line in background corresponds to the present-day bayou.

Figure 7. Conductivity survey by geologist at Site 6. Upper photograph is view looking southeast, near edge of old abandoned course. Lower photograph is view looking north at Bakers Bayou in background. At this location, there is no well-defined channel.......12

Figure 8. Major Arkansas River courses active during the Holocene (after Saucier 1994)

Figure 9. Estimated chronology of the major Arkansas River courses (Saucier 1994).

Figure 10. Bakers Bayou study area (box in blue) showing the general limits of the different Holocene (H) Arkansas River (a) meander belts. Meander belts consist of an abandoned course and 
associated abandoned channels, and point bar (p) deposits (after Saucier 1994). Cross section A-A' is presented as Figure 11

Figure 11. Geologic cross section across Snow Bayou (Arkansas Meander Belt 1) and Bakers Bayou (Arkansas Meander Belt 4), (from Saucier 1967)

Figure 12. Locations where a description of the Bakers Bayou channel was noted during the 1854 land survey of TIN, R9W. See Table 1 for summary description of channel width and character.....

Figure 13. Closeup view of Bakers Bayou Site 6 in 1937 (from photo EL6-53, flown 10 February 1937)

Figure 14. Closeup view of Bakers Bayou Site 6 in 1949 (from photo EL2f-1 18, flown 7 February 1949).

Figure 15. Closeup view of Bakers Bayou Site 6 in 1994 (from DOQQ 03409117.nws, image dated 10 March 1949).....

Figure 16. Location 15 from GLO 1854 survey (see Figure 12 and Table 1). Channel width at time of survey was 100 links or $66 \mathrm{ft}$. Center of photo marks section line intersection with Bakers Bayou

Figure 17. Location 16 from GLO 1854 survey (see Figure 12 and Table 1). Channel width at time of survey was 200 links or $132 \mathrm{ft}$. Road across Bakers Bayou in 1937 photo approximates intersection of bayou with section line. Width of bayou at road in 1937 about corresponds to survey width

Figure 18. Location 11 from GLO 1854 survey (see Figure 12 and Table 1). Channel width at time of survey was 250 links or $165 \mathrm{ft}$. Center of the photo approximates section line intersection with Bakers Bayou. Width of flooded channel in 1937 photo about corresponds to width of 1854 channel

Figure 19. Cross section across Bakers Bayou (see Figure 5 for boring locations) 


\section{Preface}

This study by the Engineer Research Development Center, Geotechnical and Structures Laboratory (ERDC-GSL), was authorized by U.S. Army Corps of Engineers, Memphis District (CEMVM), by reimbursable funding document W38XGR10362431. The project manager at CEMVM for this study was Mr. Mark Smith (CEMVM-PM-E).

The principal investigator for the geomorphic study at Bakers Bayou, Site 6, was Mr. Joseph B. Dunbar, Engineering Geology and Geophysics Branch (GG-Y), Geotechnical and Structures Laboratory (GSL), ERDC. This study was performed under the general supervision of Dr. Lillian Wakeley, Chief, Engineering Geology and Geophysics Branch, and Dr. David W. Pittman, Director, GSL.

Commander and Executive Director of ERDC was COL James R. Rowan, EN. Director was Dr. James R. Houston. 


\section{Introduction}

\section{Background}

A field trip was conducted on 9 January 2001 by personnel from several Federal and State agencies to examine a segment of Bakers Bayou, Arkansas, for coordinating agricultural water supply and ecosystem restoration requirements among the various agencies involved in project permitting and construction. The reach of Bakers Bayou under consideration is an abandoned Arkansas River course that will transport water pumped from the Arkansas River into Bakers Bayou for agricultural water needs in order to reduce aquifer pumping.

Various stops were made along the course of Bakers Bayou during the 9 January 2001 field trip as shown by Figure 1. The purpose for these stops was to examine the present condition of Bakers Bayou and compare it to site descriptions made during the 1854 Government Land Office (GLO) survey of this region. Site 6 along the field trip route was considered to represent an ideal standard for the ecosystem restoration efforts to be incorporated in the agricultural water supply channel design. This location was recommended for further background study and is the subject of the present geomorphic investigation. Additional details of the January 2001 field trip are contained in a trip report by Dunbar (2001).

\section{Purpose and Scope}

The purposes of this study were to determine the historic limits of the channel fill, to define the boundaries of the abandoned Arkansas River channel at Site 6, and to reconstruct to the extent possible the nature and character of the relict river or stream channel at this location at around 1850 . This study involves an integrated approach to the historic and prehistoric reconstruction at Site 6 and incorporates historic data, geomorphology, soils, stratigraphy, and radiometric dating methods. Activities performed during this study include a focused literature review of historic data (i.e., surveys, maps, and photographs), interpretation of aerial photography and digital imagery, examination and description of soil cores, radiometric dating of selected soil samples, development of a geologic conceptual model of the study area, and preparation of this report. 


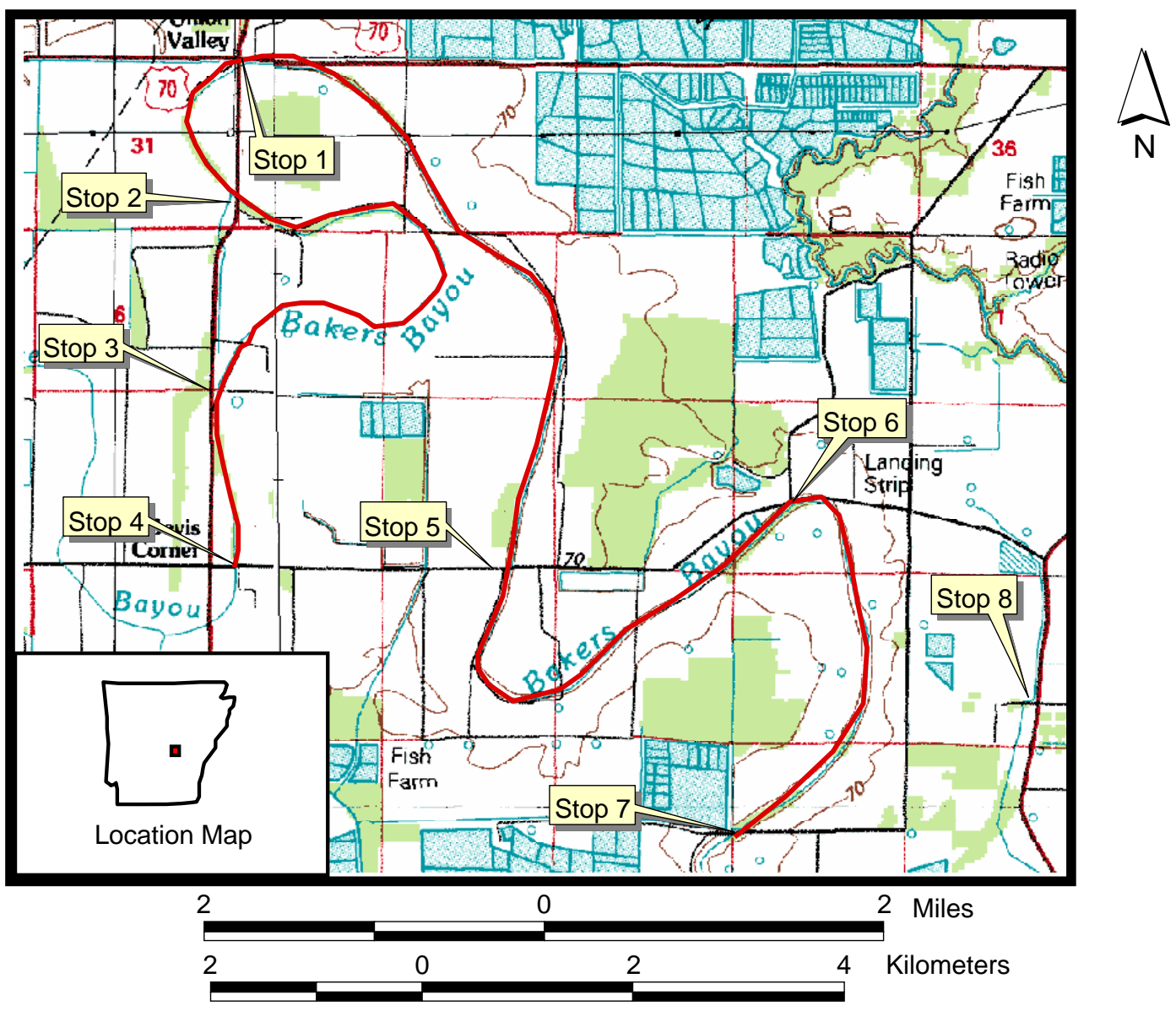

Figure 1. Location map of Bakers Bayou showing 9 January 2001 field trip stops. Site 6 (labeled Stop 6 on figure) is the focus of the current geomorphic study

\section{Study Area}

Bakers Bayou is located approximately 16 miles $(27 \mathrm{~km})$ due east of Little Rock, AR, and 6 miles $(10 \mathrm{~km})$ due south of Interstate 40 in Lonoke County. Bakers Bayou is an abandoned Arkansas River course that was active approximately 6,000 to 8,000 years before present (Saucier 1994). The abandoned course has been subsequently filled with sediment and presently serves as a local drainage. Bakers Bayou is a prominent topographic feature on the landscape and is part of the Holocene (less than 10,000 years) floodplain of the Arkansas River.

The area of interest is identified as Stop 6 on Figure 1 and is located on the Pettus U.S. Geological Survey (USGS) 7-1/2-min. topographic quadrangle. Bakers Bayou at Site 6 is a $300-\mathrm{ft}-(100-\mathrm{m}-)$ wide forested corridor that is situated within the banks of the old Arkansas River channel. Standing water is currently present within the center of the old river channel where surface drainage collects (Figure 2). The old river channel is not evident at Site 6. Rather, this channel has been completely filled and all that remains is a poorly drained 
forested area, occupying the approximate center of the old river channel. Along a significant part of the Bakers Bayou reach shown in Figure 1, the forests have been clear-cut to permit farming adjacent to the old channel, and also to provide water storage for livestock and/or irrigation needs (Figure 3).

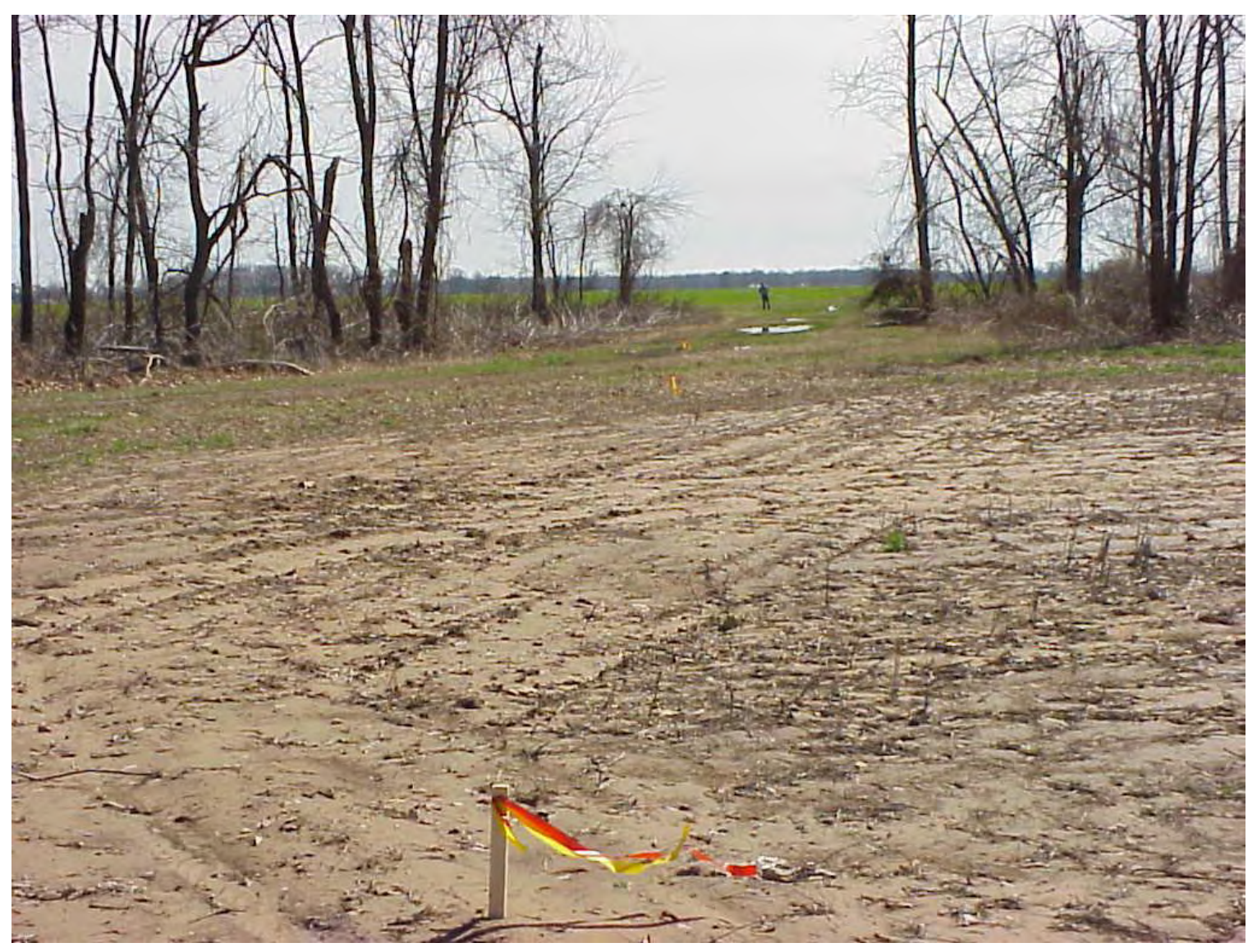

Figure 2. View across Bakers Bayou at Site 6. Trees in the middle of the photograph correspond to the approximate center of the old Arkansas River course at this location 


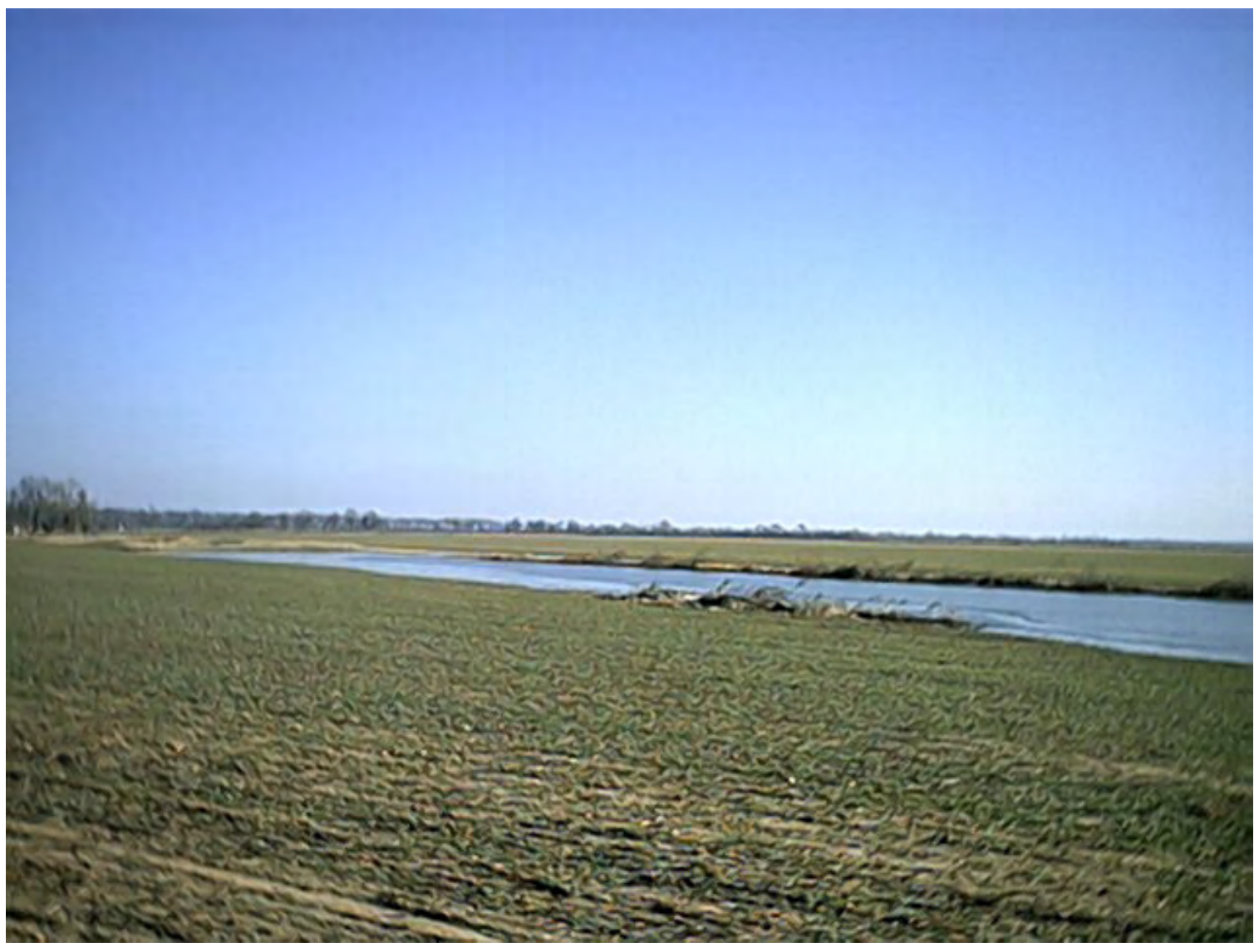

Figure 3. View across Bakers Bayou at Site 3 (see Figure 1 for photo location) 


\section{Methods}

\section{Historic Data}

Historic data were collected to better understand past land use changes that have occurred in the study area. Relevant surveys, maps, aerial photographs, and digital images were obtained to compare land use changes and determine the limits of the abandoned course. Historic data collected for this study include the following coverages:

a. Surveys and U.S. Geological Survey (USGS) Maps.

(1) 1855 Government Land Office Survey. Presents surveyor's description of Bakers Bayou along the Township and Range Section lines. Index map from this survey shows earliest mapped location of Bakers Bayou course.

(2) 1891 Little Rock Topographic Quadrangle, Camp Pike. Scale 1:125,000, Map shows location of Bakers Bayou West of Site 6, beginning at $92^{\circ}$ West Longitude.

(3) 1937 England USGS Topographic Quadrangle. Scale 1:48,000.

(4) 1943 England USGS Topographic Quadrangle. Scale 1:62,500.

(5) 1982 Pettus USGS Topographic Quadrangle. Scale 1:24,000.

(6) 1982 Pettus USGS Digital Raster Graphics (DRG). Scale $1: 24,000$.

b. Aerial Photography and Imagery.

(1) 1937 Black-and-White Aerial Photography. Scale 1:20,000, Flown for U.S. Department of Agriculture (USDA) by Bowman Park Aero Co., Louisville, KY. This coverage is the earliest known aerial photographic coverage for this area.

(2) 1949 Black-and-White Aerial Photography. Scale 1:20,000, Flown for USDA by Tobin International, San Antonio, TX. 
(3) 1994 Black-and-White Digital Ortho Quarter Quads (DOQQ).

Scale: 1 -m pixel resolution

\section{Aerial Photo Interpretation}

Historic maps and aerial photography obtained for the study area were carefully examined to determine channel boundaries and the presence of inset stream channels. Selected photographs were digitally scanned, rectified to a digital base map, and then overlaid onto each other using ArcView Geographic Information System (GIS) software from Environmental System Research Institute (ESRI). Digitally rectified photographs and imagery permit close and spatially accurate examination of the geomorphic and man-made features. Land use changes, channel boundaries, and other important landform characteristics were evaluated and the geomorphic features mapped onto the USGS DRG for the England quadrangle in ArcView to produce the generalized geomorphic map in Figure 4 and the topographic-based, geomorphic map in Plate 1.

\section{Drilling and Sampling}

Six stratigraphic soil borings were drilled within the Bakers Bayou channel at locations identified in Figure 5. Boring locations were selected with two cores on the inside margins of the old channel and the remaining four cores located at the center of the old channel. The purpose for the soil sampling was to obtain detailed stratigraphic and lithologic information on channel filling. Stratigraphic and lithologic data are necessary to distinguish between the prehistoric and the documented historic limits of channel fill. For purposes of this study, the historic-prehistoric boundary has been set by the U.S. Army Engineer District, Memphis (CEMVM), at about 1850.

Soil sampling was conducted with a CEMVM Failing 1500 drill rig and crew (Figure 6). Both disturbed and undisturbed soil samples were taken for later laboratory study. Boring advance between samples was performed with a bucket-type soil auger. Disturbed or general type samples were obtained with a standard split spoon. Undisturbed soil samples were obtained with a 3-in. $(7.62-\mathrm{cm})$ Shelby or open-tube type sampler that was hydraulically pushed to refusal or to the desired sample depth. Split spoon samples were taken where hydraulic push type techniques were not effective (boring BB-1) or where near-surface samples were lost because of saturated soil conditions (boring BB-3). Complete information regarding sampling techniques for disturbed and undisturbed methods is contained in Engineer Manual 1110-1-1906 (U.S. Army Corps of Engineers 1996).

The maximum sample depth was set at the base of the topstratum or the vertical accretion portion of the channel-fill sequence. The maximum sample depth was based on an existing cone-penetrometer boring from Bakers Bayou (Figure 5) and previous subsurface mapping (by Saucier 1967). These data indicate a finegrained topstratum between 15 and $20 \mathrm{ft}$ (4.6 to $6.1 \mathrm{~m}$ ) thick, underlain by coarse- 
grained lateral accretion deposits greater than $40 \mathrm{ft}(10 \mathrm{~m})$ thick. The thickness of the topstratum at Site 6 varies between 12 and $16 \mathrm{ft}$ ( 3.6 and $4.8 \mathrm{~m}$ ) based on the borings drilled for this study. The vertical accretion or fine-grained component of the channel fill is important for understanding the filling history as the upper stratigraphy can provide important clues on the filling mechanism.

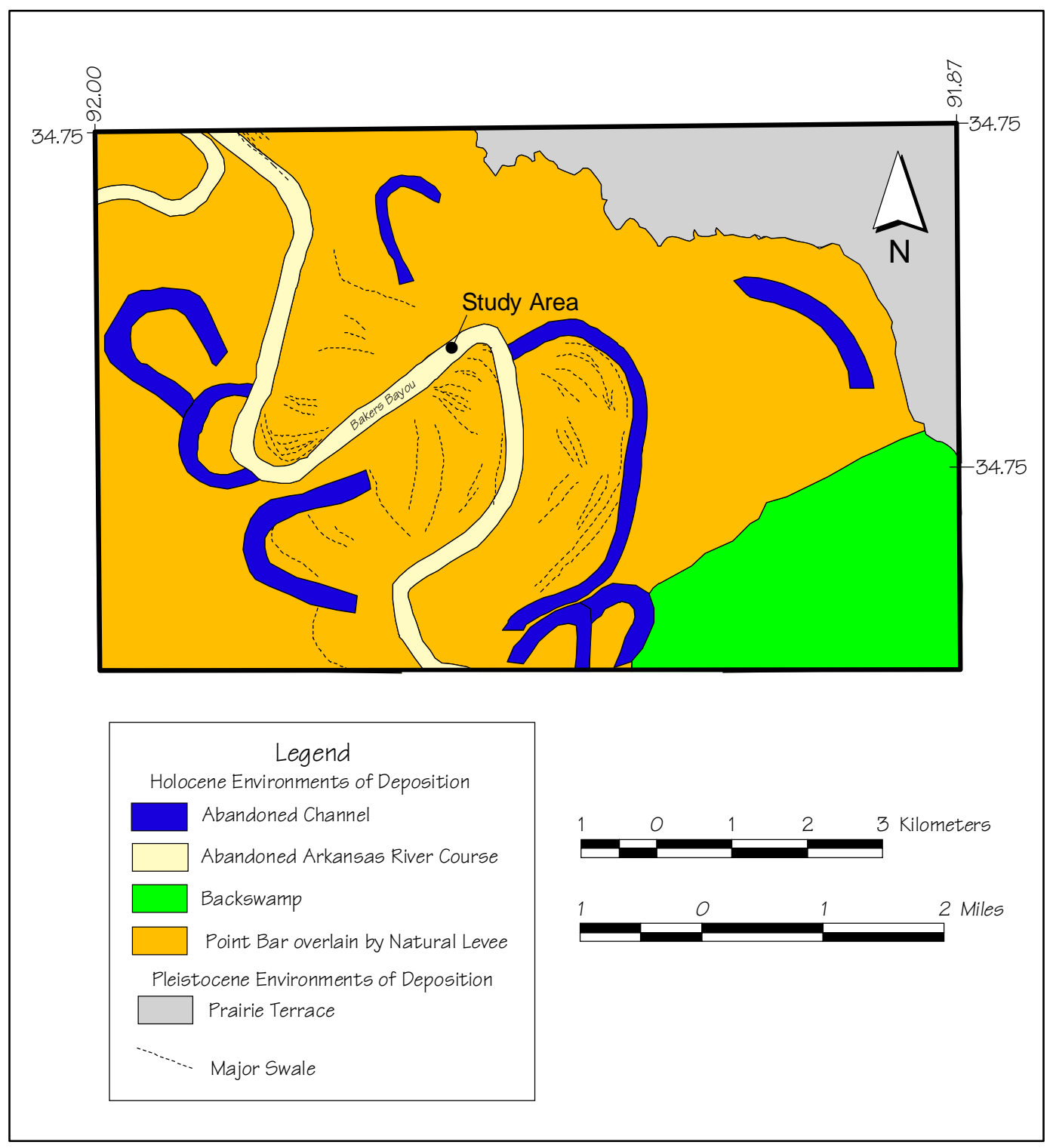

Figure 4. Geomorphic map of the Bakers Bayou study area showing major fluvial landforms (modified from Saucier 1994)

\section{Soil Cores}

Soil cores from the Bakers Bayou drilling were transported to the Engineer Research and Development Center, Waterways Experiment Station (ERDCWES) for laboratory evaluation. Samples were extruded from the Shelby tube by 
using either a hydraulic ram or simply by cutting the Shelby tube longitudinally on either side with an electric circular saw and metal cutting blade. In both of the extruding techniques, soil samples were split in half to permit description of the lithology and stratigraphy.

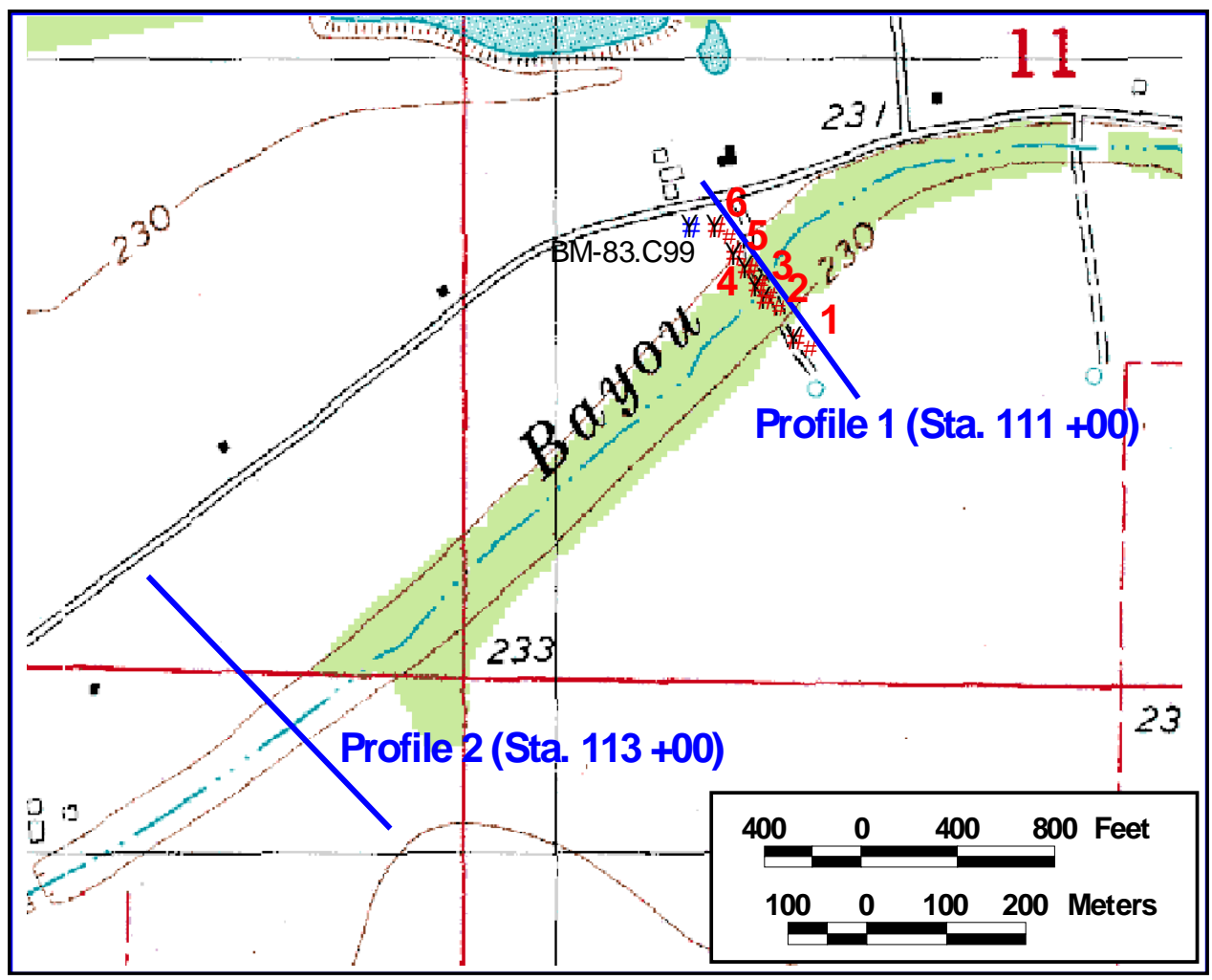

Figure 5. Location of borings drilled as part of this study (red circles), topographic profiles (blue line), referenced cone penetrometer boring (blue circle), and conductivity survey (same as profile locations, blue line)

Soil boring logs are presented in Appendix A. Each boring log in Appendix A contains the drilling inspector's sample description sheet and a description of the soil samples by a geologist on ERDC-WES Form 819, Field Data Boring Log. Description of the soil on Form 819 in Appendix A contains lithology according to the Unified Soil Classification System (USCS). Included with the classification are Munsell color, soil consistency, moisture content, presence and character of mottles, type of bedding or laminations that are visible, character and content of organic matter, and other features that relate to the stratigraphy or mineralogy of the sediments. These data are discussed in more detail in a subsequent section of this report. 


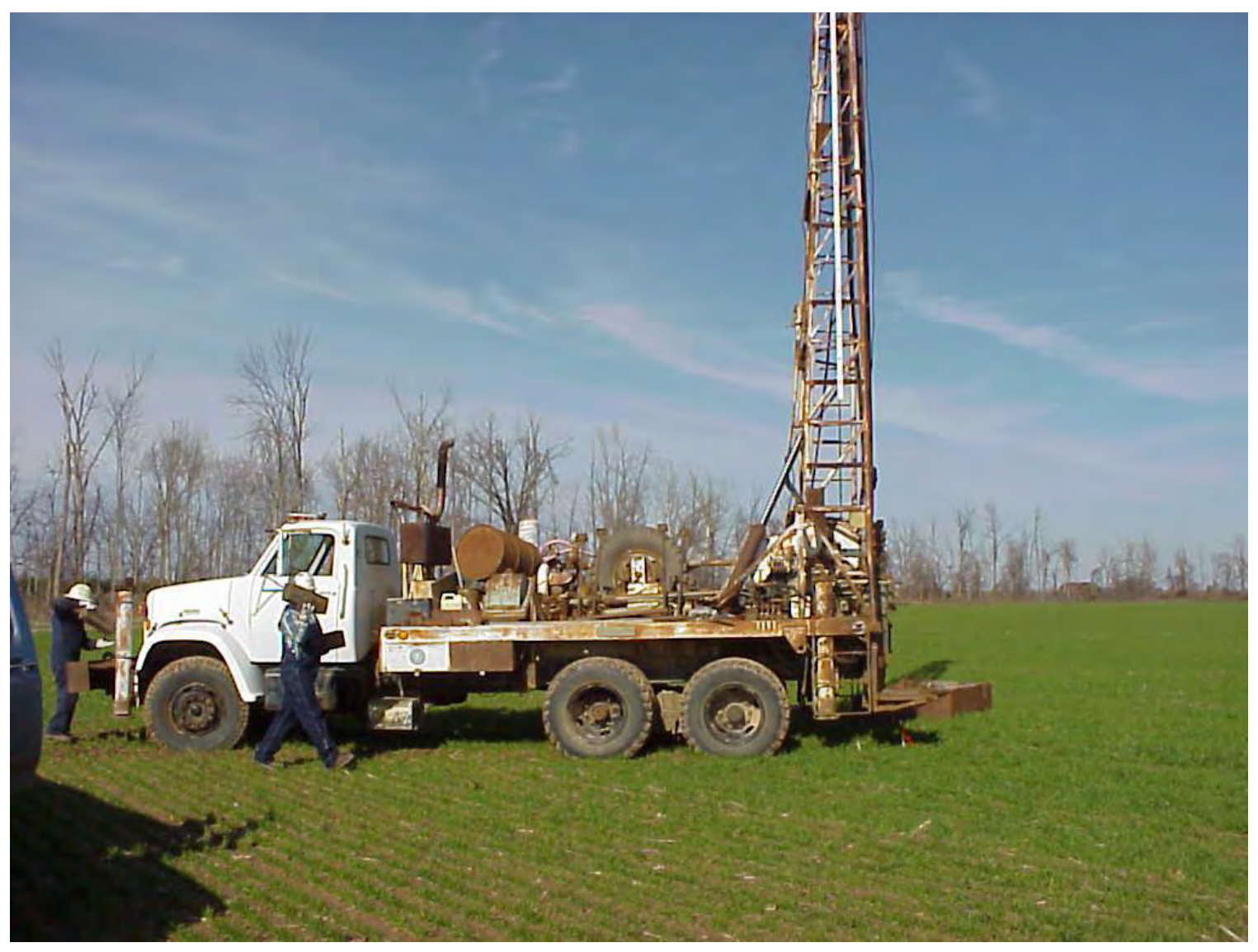

Figure 6. Drilling equipment used to sample at Bakers Bayou, Site 6. Drill rig is set up within the old channel of the abandoned Arkansas River course. Tree line in background corresponds to the present-day bayou

\section{Radiometric Dating of Soil Samples}

Radiometric dating techniques were used in this study to calibrate the chronology of the stratigraphy and estimate sedimentation rates for channel filling. Radiometric dating is based on the radioactive decay of specific isotopes in sediments. Isotopes of interest to this study include cesium-137, lead-210, and carbon-14 (C-14). These three radiometric dating techniques were employed on soil samples from core BB-4 (Figure 5). This core is located within the active part of the present "channel." No sample loss was reported for this core on the sample boring sheet that was submitted by the CEMVM field inspector.

Radiometric dating techniques are based on the known half-life of specific isotopes and the ability to count the decay or activity rate of these isotopes with highly sensitive laboratory instruments. Cesium-137 has a half-life of 30.3 years and is a byproduct of atmospheric testing of thermonuclear weapons. This isotope was first introduced in 1952 and peaked during 1963 and 1964. Its presence in the soil and the characteristics of these peak signatures allows for the dating of soils and determining sedimentation rates for ecological studies. 
Similarly, lead-210 has a half-life of 22.3 years and is a by-product of the uranium-238 decay series. Lead-210 forms by the decay of radon-222 in the atmosphere. Precipitation removes this isotope from the atmosphere, and the lead-210 isotope is rapidly absorbed by sediment. Dates of sediment deposition by this technique are calculated by determining the decrease in lead-210 activity as a function of time.

Carbon-14 is produced in the earth's atmosphere by the interaction of cosmic radiation with nitrogen and to a lesser extent with oxygen and carbon. Carbon- 14 is rapidly assimilated into the carbon cycle and is incorporated into the tissue of all living organisms. Upon the death of the host organism, the C-14 isotope decays at a fixed rate according to its half-life of 5,730 years. It is assumed that no new carbon is introduced into the closed system. The effective range of applicability of C-14 dating is between 100 and 50,000 years.

Sediment dating by cesium-137 and lead-210 was performed by the USGS, Center for Coastal Geology, St. Petersburg, FL. Dr. Chuck Holmes, a USGS Geologist, sampled the upper $6 \mathrm{ft}$ ( $\sim 2 \mathrm{~m}$ ) of core from BB-4 at the ERDC-WES. Additionally, one sample was selected for $\mathrm{C}-14$ dating that was below the cesium-137 and lead-210 samples. The C-14 sample was submitted to Beta Analytical, Coral Gables, FL, for accelerated mass spectrometry (AMS) C-14 dating. AMS techniques were required since the quantity of carbon was insufficient to date the sample by conventional C-14 methods. Detailed information about these techniques is presented on the USGS Web site at http://sofia.usgs.gov/publications/fs/73-98/. Results of the radiometric dating from these various techniques are presented in Appendix B (Cesium and Lead-210 Results) and C (Carbon-14 Results).

\section{Topographic Profiles}

Two elevation profiles were surveyed by CEMVM across Bakers Bayou to define the surface topography across the abandoned course. Profiles were made at Site 6 and across an open field about 2,400 ft (732 m) southwest of this location (Figure 5). Profiles were made at these two locations to provide topographic evidence of the channel boundaries. Topographic profiles are presented in Appendix D. Topographic profiles are identified as section $111+00$ (corresponds to profile 1 in Figure 5). The profile southwest of Site 6 is identified as section $113+00$ in Appendix D (corresponds to profile 2 in Figure 5).

\section{Conductivity Survey}

A reconnaissance-level geophysical survey was made across Bakers Bayou at two locations identified in Figure 5. The survey was performed by walking across the old channel and recording the conductivity values at 5-m (16-ft) intervals. The purpose for the geophysical survey was to delineate the boundaries of the old channel from the electrical properties of the underlying soils. 
A Geonics EM-31 instrument was used to survey across the old channel (Figure 7). The Geonics EM-31 is an electromagnetic (EM), fixed frequency $(9,400 \mathrm{~Hz})$ transmitter and receiver that measures electrical conductivity. The sample frequency for the transmitter and receiver was twice per second. An analog display on the EM-31 console shows conductivity values in real-time and instantly identifies changes in bulk conductivity values due to variations in the underlying geology.

The general principle behind the survey is that a change in the underlying depositional environment will produce differences in the electrical properties of the soil. Thick channel sands contained in the abandoned course should produce a difference in the electrical conductivity values compared with areas outside the old channel. Areas that are adjacent to the abandoned course correspond to natural levees, point bars, or backswamps (Figure 4). Results of the EM-31 survey indicate that the area within the channel has a lower conductivity (high resistivity) while, in the area outside of the channel (i.e., natural levees), the conductivity is higher (low resistivity) because of the increased clay content. Results of the conductivity survey at Site 6 compare favorably with other evidence collected to determine the location of the channel boundaries. 

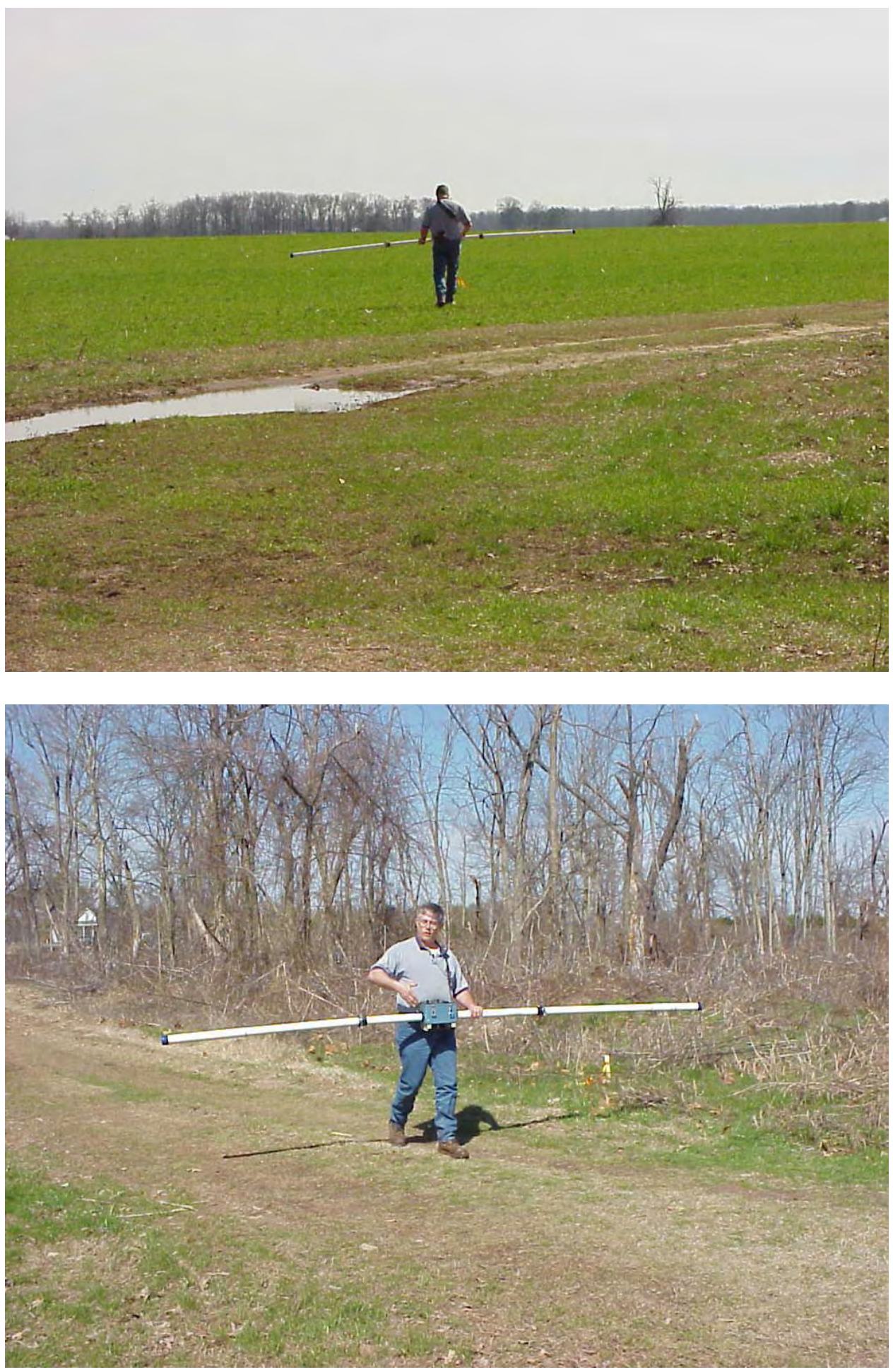

Figure 7. Conductivity survey by geologist at Site 6 . Upper photograph is view looking southeast, near edge of old abandoned course. Lower photograph is view looking north at Bakers Bayou in background. At this location, there is no well-defined channel 


\section{Geologic Setting}

\section{Arkansas River Courses and Meander Belts}

Major Arkansas River courses that were active during the Holocene are identified in Figure 8. Bakers Bayou is identified as course 4a in Figure 8. This course is estimated to be 6,000 to 8,000 years old and corresponds to course 4 in Figure 9. The chronology of the Arkansas River courses is based on over 30 years of engineering geology mapping by ERDC-WES in the Lower Mississippi Valley (USAE Waterways Experiment Station 1951, Saucier 1964, Saucier 1967) and numerous site-specific studies, including chronostratigraphic data (Saucier 1994).

Associated with each Arkansas River course identified in Figure 8 are specific environments of deposition. The major depositional environments are an abandoned course and associated abandoned channels, point bars, and backswamp deposits. Together, these environments have formed a meander belt complex (Figure 10).

\section{Bakers Bayou Study Area}

\section{Pleistocene floodplain}

The part of Bakers Bayou meander belt complex under study is bordered by the Pleistocene Grand Prairie to the east, and Holocene floodplain deposits to the west (Figure 10). The Grand Prairie is a Sangamon age (75,000 to 125,000 years old) floodplain of the Arkansas River that was created during the previous interglacial cycle. This older floodplain surface is approximately 5 to $9 \mathrm{ft}$ (1.5 to $2.7 \mathrm{~m}$ ) higher in elevation than the present-day floodplain of the Arkansas River. Depositional environments forming this older surface are similar to those active on the modern floodplain.

In addition to the Grand Prairie, a second, younger Pleistocene surface is present southeast of the Bakers Bayou study reach (Figure 10). This surface represents a late Pleistocene floodplain that is characterized by oversized meander loops attributable to higher levels of precipitation and runoff at that time. The exact chronology for this surface is tentative, but has been estimated at 12,000 to 20,000 years before present (Saucier 1994). 


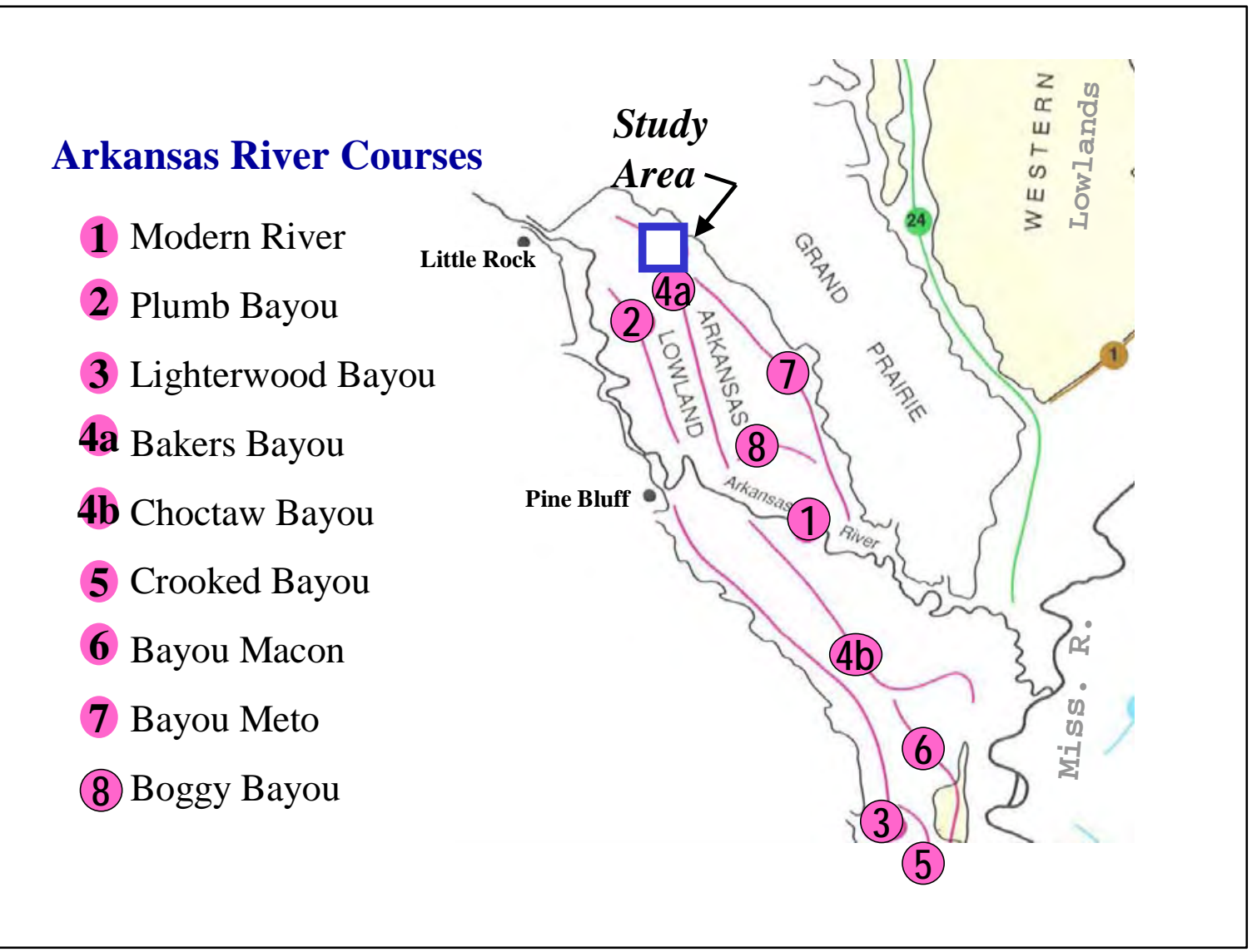

Figure 8. Major Arkansas River courses active during the Holocene (after Saucier 1994)

\section{M eander Belt Chronology}

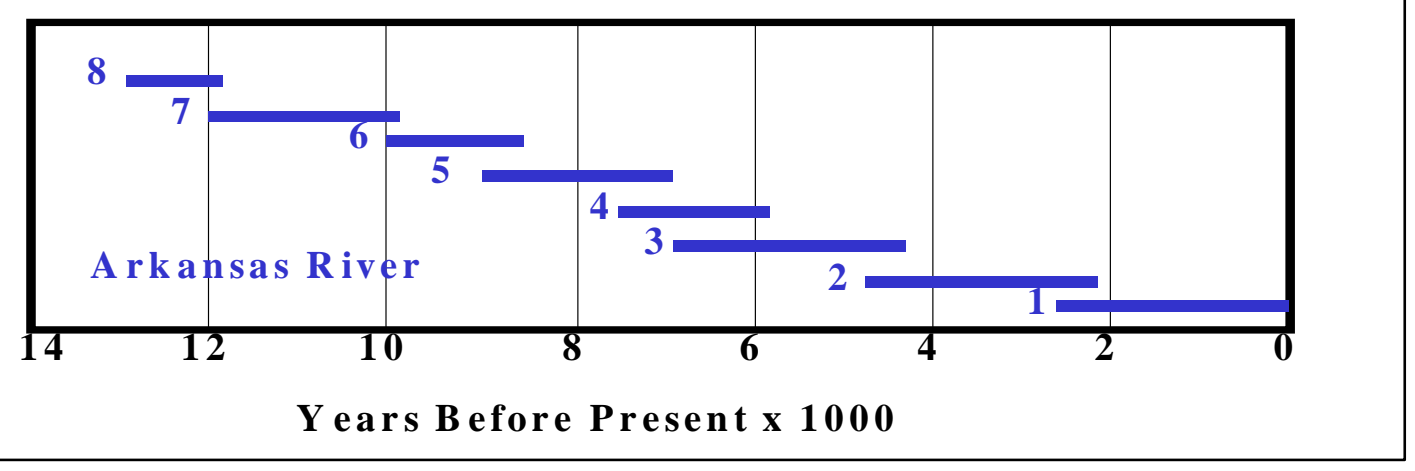

Figure 9. Estimated chronology of the major Arkansas River courses (Saucier 1994) 


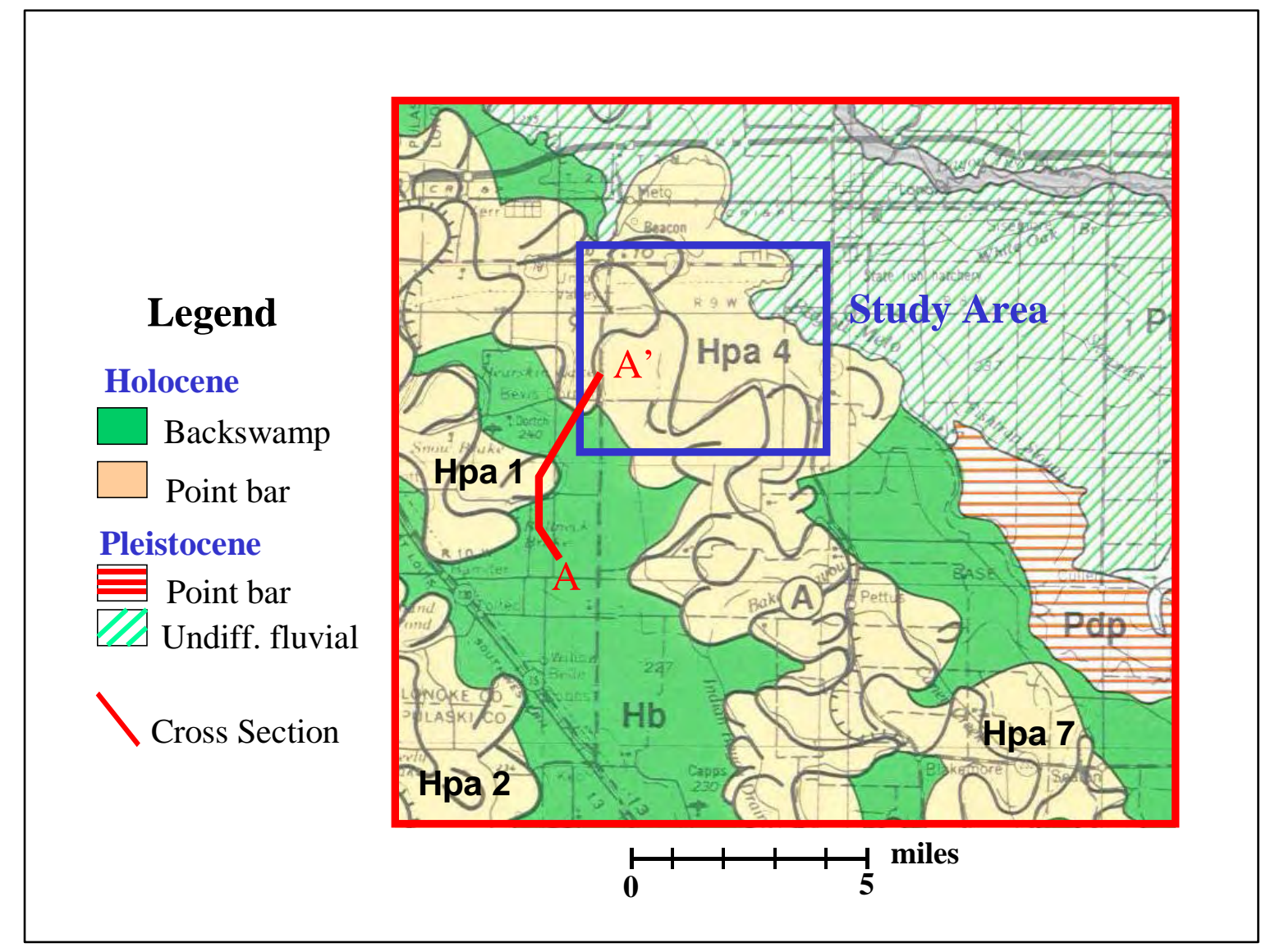

Figure 10. Bakers Bayou study area (box in blue) showing the general limits of the different Holocene ( $\mathrm{H}$ ) Arkansas River (a) meander belts. Meander belts consist of an abandoned course and associated abandoned channels, and point bar ( $p$ ) deposits (after Saucier 1994). Cross section A-A' is presented as Figure 11

\section{Holocene floodplain}

Meander belt deposits associated with Bakers Bayou are approximately 5 miles wide at Site 6 (Figure 10). Environments of deposition that formed the study area include the Bakers Bayou abandoned course, abandoned channels, natural levees, point bars, and nearby backswamp (Figure 4 and Plate 1). A summary of each environment is presented below to provide a general geologic framework for a closer study of Site 6.

Abandoned course. An abandoned course is a river channel that is abandoned in favor of a more hydraulically efficient course. An abandoned course contains a minimum of two meander loops and forms when the river's flow path is diverted to a new position on the river's floodplain. The method by which a river abandons one course in favor of another course is a gradual process. It generally begins by a break or a crevasse in the river's natural levee during flood stage. The crevasse forms a temporary channel that over time may develop into a permanent channel. A change in the river's course is due to a more hydraulically 
efficient route across the floodplain, whereby the gradient of the new river channel is steepened by a reduction in the course length. As shown in Figures 8 through 10, the Arkansas River has experienced numerous course shifts during the Holocene.

The Bakers Bayou abandoned course is estimated to have been active between 6,000 and 8,000 years before present (Saucier 1994) and the channel has since been sediment filled. Channel filling is dominated by coarse-grained sediments, consisting of sand and silty sand at the base of the channel, overlain by silt and clay at the surface. Engineering geology mapping by Saucier (1967) indicates the Bakers Bayou course is approximately $50 \mathrm{ft}$ (15 m) deep (Figure 11). Channel filling involves two types of sediments and distinct fluvial processes. The base of the abandoned course consists of coarse-grained substratum sands, which are formed by lateral accretion (i.e., channel migration). In contrast, the upper part of the channel fill consists of a fine-grained topstratum, which forms by vertical accretion or overbank deposition.

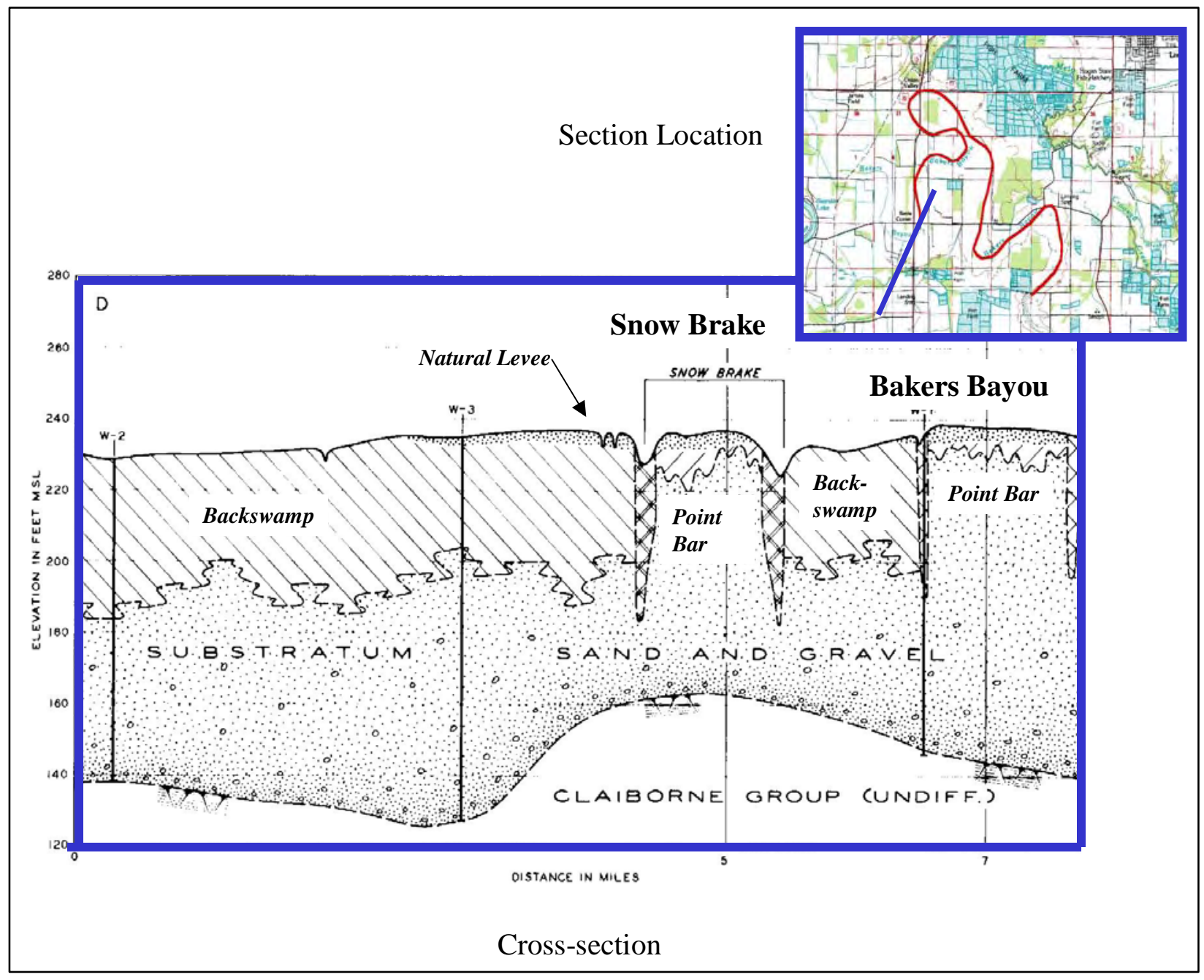

Figure 11. Geologic cross section across Snow Bayou (Arkansas Meander Belt 1) and Bakers Bayou (Arkansas Meander Belt 4), (from Saucier 1967) 
At Site 6, a cone penetrometer was pushed to a depth of $50.5 \mathrm{ft}(15.39 \mathrm{~m})$ to obtain a sample at location BM-83-C99 (Figure 5). Textural data identify a sandy substratum (silty sand and sand) below $22 \mathrm{ft}(6.7 \mathrm{~m})$. Above this interval, the channel is filled with a fining upward sequence, grading from silt to clay and then back again to silt at the surface. The upper surface silt sequence corresponds to overbank, natural levee deposits inset within the old course. A similar filling sequence is identified in other cone-penetrometer borings from the Bakers Bayou course.

Abandoned channel. An abandoned channel forms when a river migrates across its point bar and cuts off a loop segment to form an oxbow lake. The process by which the river abandons the loop occurs either gradually or during a single flood event. For a cutoff to form gradually, river migration permits the upper and lower ends of the channel to come together, and then separate from the main course during a high-flow event. A rapid cutoff during a single flood event is possible by a chute or high-water channel developing across the point bar neck and flood flow creating a permanent channel across the point bar. Both neck and chute cutoffs are present in the Bakers Bayou reach shown in Figure 4. An excellent example of a cutoff that is in the process of forming is the northernmost loop of Bakers Bayou in Figure 1 where the two arms of the course are touching.

Abandoned channels help define the boundaries of a meander belt complex. The ends of the abandoned channels are usually oriented toward the trunk course. Generally, abandoned channels and courses have different physical properties. An abandoned course will maintain a hydraulic connection to the floodplain over an extended period of time and will carry low-stage channel flow. Abandoned courses are much coarser grained deposits as a whole than are abandoned channels. Abandoned channels typically contain finer grained deposits, because they are usually separated from the trunk channel and receive sediments only by overbank deposition during flood flow.

Backswamp. Backswamp deposits are vertical accretion deposits that receive sediment during times of high-water flow. Deposition occurs when the natural levees are crested, and suspended sediment in the floodwaters is carried to the distal parts of the floodplain. Backswamp deposits are confined to the southeastern part of the Bakers Bayou reach (Figure 4).

Primary geomorphic processes active within this environment are vertical accretion of new sediment from annual flooding (presently not possible with construction of levees), pedogensis (soil formation), and bioturbation (churning and stirring of the underlying sediment by vegetation and organisms). Saucier (1967) identifies backswamp deposits in the study area as being from 40 to $50 \mathrm{ft}$ (9 to $12 \mathrm{~m}$ ) thick (Figure 11).

Natural levee. Natural levee deposits are not mapped as a separate environment on the geomorphic map (Figure 4 and Plate 1). This environment is represented throughout the study area to some extent, and mapping the limits would detract from the basic map information. Natural levee deposits were mapped in combination with the point bar environment, but are described as a separate environment because of their importance to the study area. 
Natural levees are vertical accretion deposits formed when the river overtops its banks during flood stage and sediment suspended in the flood flow is deposited adjacent to the channel. The resulting landform is a low, wedgeshaped ridge, decreasing in thickness with distance from the levee crest. Natural levee deposits eventually merge with other floodplain deposits. Within the study area, natural levee deposits merge with backswamp and point bar sediments.

Silt and fine-grained sand are the dominant grain size in natural levee deposits. Within the old course at Site 6 , silt is the primary soil texture for the surface sediments. These deposits generally contain little organic material because of oxidation. Soil color ranges from tan to orange brown (see boring logs, Appendix A).

Natural levee topography at Site 6 is defined by profile 1 (see Figure 5 for location and Appendix D, profile labeled station $111+00$ ). This profile shows the slight rise in elevation along either side of the old course. At this location, the peak elevation is at survey distance $160 \mathrm{ft}$ (approximate roadway) and $920 \mathrm{ft}$ (open field) from the origin of the profile. The second profile does not extend completely across the old channel, but the right (south) bank levee is evident by the increase in elevation at survey distance $700 \mathrm{ft}$ from the profile origin (Appendix D).

Point bar. The dominant depositional environment in the Bakers Bayou reach is point bar (Figure 4 and Plate 1). Point bar deposits are formed as a river migrates across its floodplain. River channels migrate by eroding the outside or concave bank, and depositing a sandbar on the inside or convex bank. With time the convex bank grows in size as the river migrates laterally, and the point bar is developed. Associated with the point bar is a series of arcuate rises and swales, or low-lying depressions, between the accreted sandbars. Swales are locations where fine-grained sediments accumulate by vertical accretion or overbank deposition. Point bars are easily recognized on aerial photography and topographic maps by the characteristic ridge and swale topography, and by the presence of numerous abandoned channels on the floodplain.

Point bar deposits are as thick as the total depth of the river channel in which they form. Point bar deposits at Site 6 are approximately $50 \mathrm{ft}(15 \mathrm{~m})$ thick. These deposits fine upward from the maximum size of the river's bedload (coarse sand and/or gravel, Figure 11) to fine-grained soils at the surface (silt and clay). The basal portion of the point bar sequence (the substratum) forms by lateral accretion, while the fine-grained or upper portion (the topstratum) forms by vertical accretion. These two processes are fundamentally different mechanisms for sediment transport and deposition by a fluvial system. 


\section{Discussion of Site Data}

\section{Width of Abandoned Course at Site 6}

The lateral limits of the abandoned course in the Bakers Bayou reach were determined from historic aerial photography, topographic information (Appendix D), and site conductivity data at Site 6. These data indicate a channel that was between 600 and $900 \mathrm{ft}$ (182 and $274 \mathrm{~m}$ ) wide when the course was active between 6,000 and 8,000 years before present (ybp).

The maximum channel width at Site 6 is between 700 and $830 \mathrm{ft}$ (213 to $253 \mathrm{~m}$ ). Aerial photography from 1937 indicates the channel at Site 6 is about $700 \mathrm{ft}$ (213 m) wide. The limits of the channel from topographic data (Appendix D) indicate the channel is about $710 \mathrm{ft}(216 \mathrm{~m})$ wide, while conductivity data would suggest a maximum width of about $830 \mathrm{ft}(253 \mathrm{~m})$. Channel width based on conductivity data represents a maximum value and probably reflects a significant increase in the fine-grained soils associated with the adjacent natural levee deposits. In summary, these different data are in general agreement with each other about the width of the middle Holocene channel.

\section{Historic Limits Based on Site Surveys and Maps}

Careful study of old photography, maps, and survey data is required to establish the historic channel limits. Historic map and survey data examined during this study were listed in Chapter 2 of this report.

Topographic map data examined for this study indicate no significant changes in course location. All printed maps identify a course that has remained constant and stable during historic time as would be expected from a system that was abandoned approximately 6,000 years ago. The resolution or scale (i.e., $1: 24,000$ to $1: 62,500)$ of these topographic maps does not permit detailed reconstruction of channel dimensions.

A source of historic data that permits detailed examination of channel dimensions is the land survey of 1854 by John W. Garretson, D.S. The survey was performed under a 15 May 1854 contract to the Treasurer of the United States, and was commissioned to correct an error in the original survey of December 1815 for Township 1 North of the base line and Range 9 West of the 5th Principal 
Meridian (T1N, R9W). The survey was conducted to establish the section lines within this township and range. The original 1815 survey was made to establish the boundaries for the lands acquired by President Jefferson in the Louisiana Purchase of 1803.

A portion of the 1855 plat map for T1N, R9W, is presented as Figure 12 with Site 6 identified and those locations where a description of the Bakers Bayou channel was noted during the survey. Survey locations identified in Figure 12 are at the intersection of Bakers Bayou with the section lines. The relevant surveyor's descriptions are summarized in Table 1 by their numbered location in Figure 12. The numbering convention in Figure 12 is based on previous work by Mr. Tom Foti, Arkansas Natural Heritage Commission.

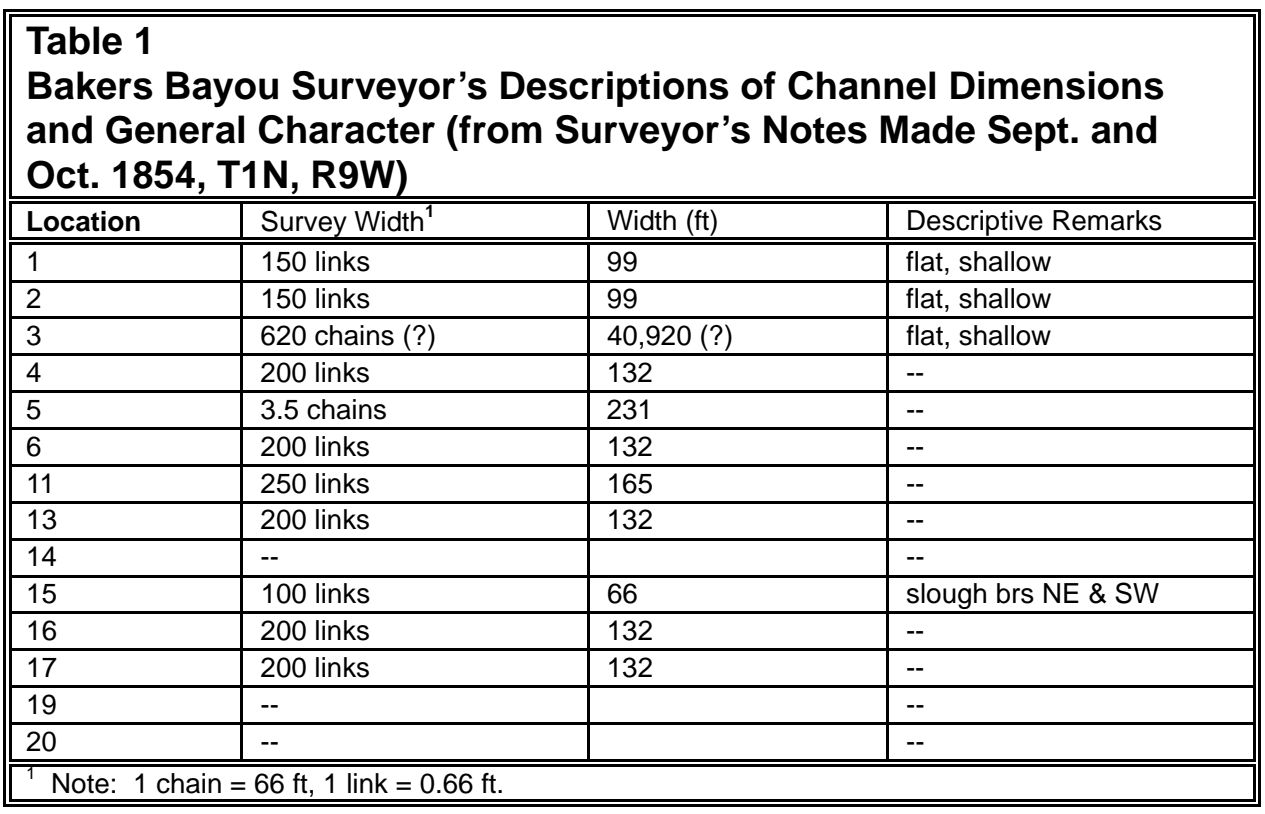

Examination of Table 1 shows the channel dimensions in September and October 1854 as ranging between 66 and $231 \mathrm{ft}$ (20 and $70 \mathrm{~m}$ ). An erroneous value for channel width is believed reported for location 3 . This high value may represent a transcription error when the survey was typed and/or possibly a missing decimal point. The average value for channel width excluding location 3 is $132 \mathrm{ft}(40 \mathrm{~m})$. The channel is described at three locations as being flat and shallow.

\section{Historic Limits Based on Photos and Imagery}

Historic photography examined for this study includes the 1937 and 1949 USDA black-and-white prints at a 1:20,000 scale and DOQQ imagery from 1994. A comparison of the channel conditions was made for the three time periods using georeferenced images in ArcView. A closeup view of Site 6 for these three time periods is presented in Figures 13 through 15. 


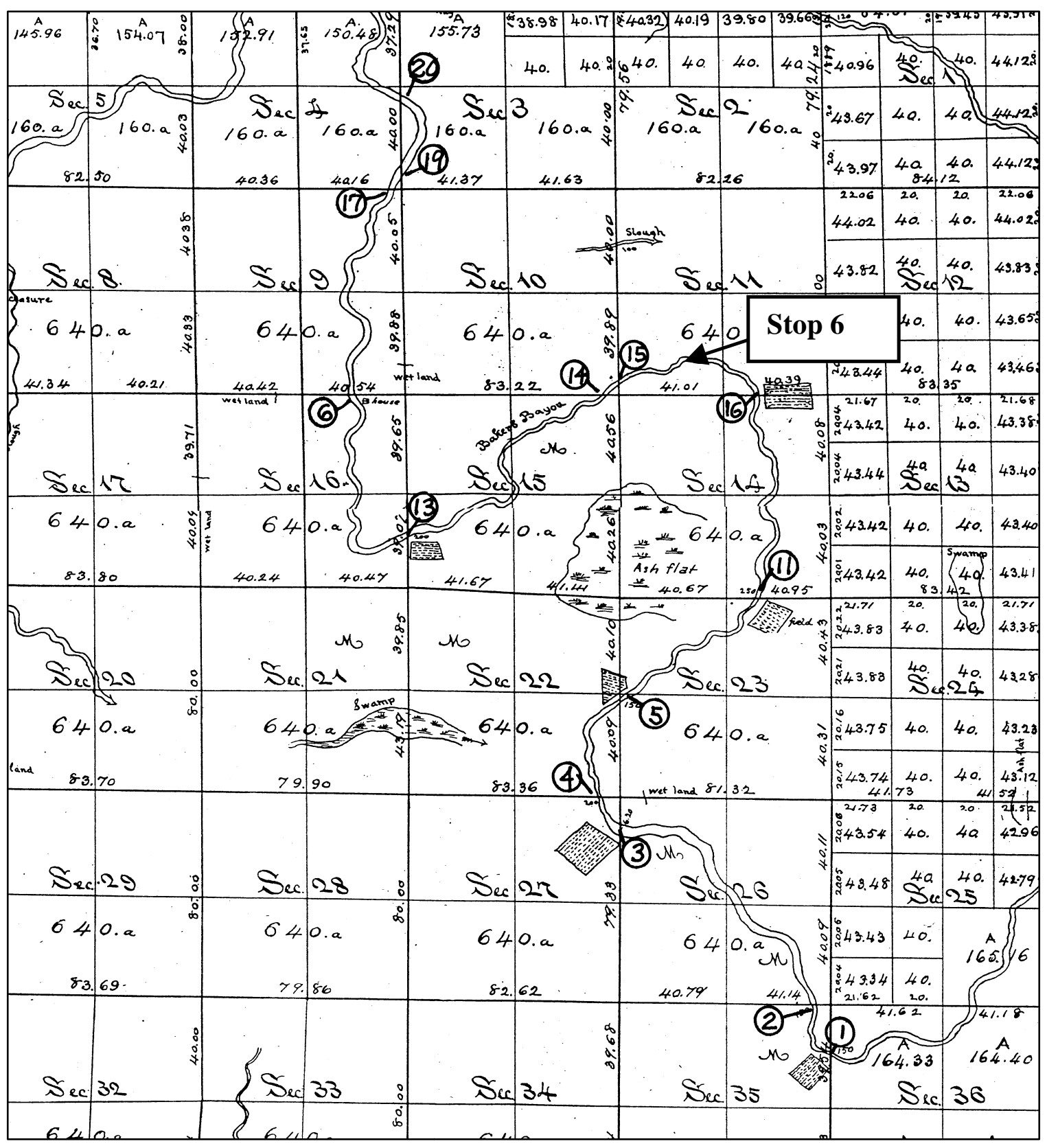

Figure 12. Locations where a description of the Bakers Bayou channel was noted during the 1854 land survey of T1N, R9W. See Table 1 for summary description of channel width and character 


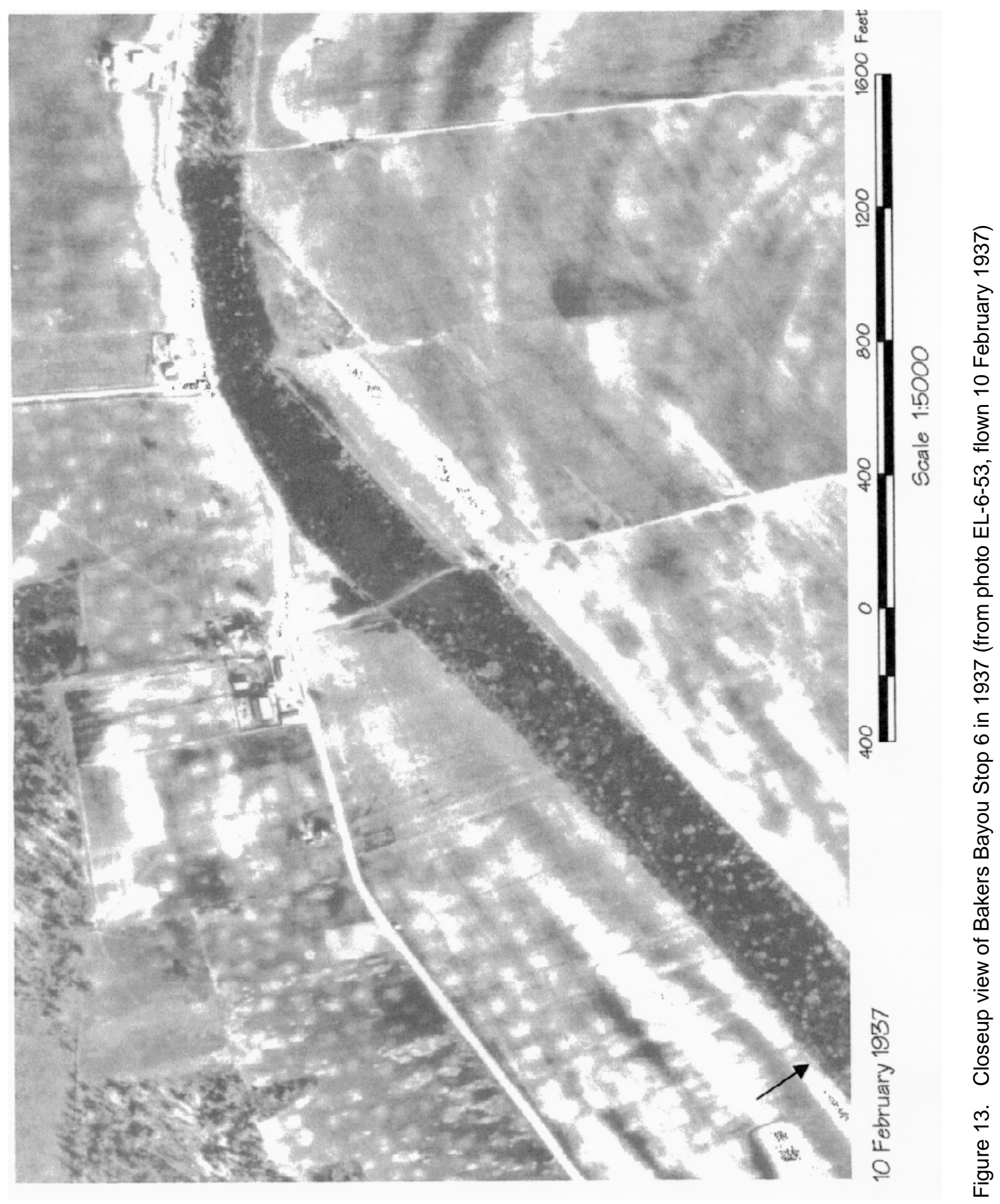




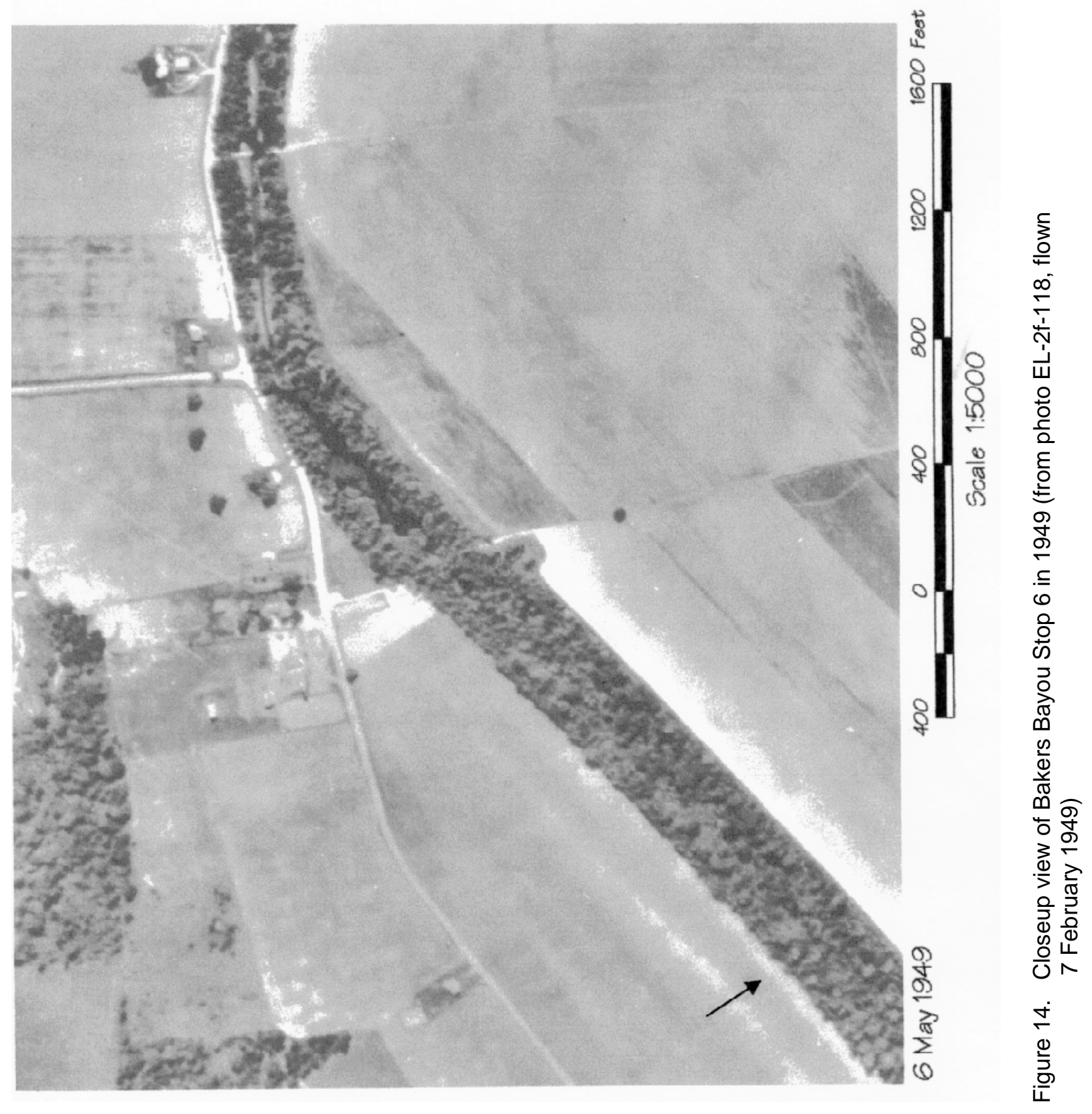




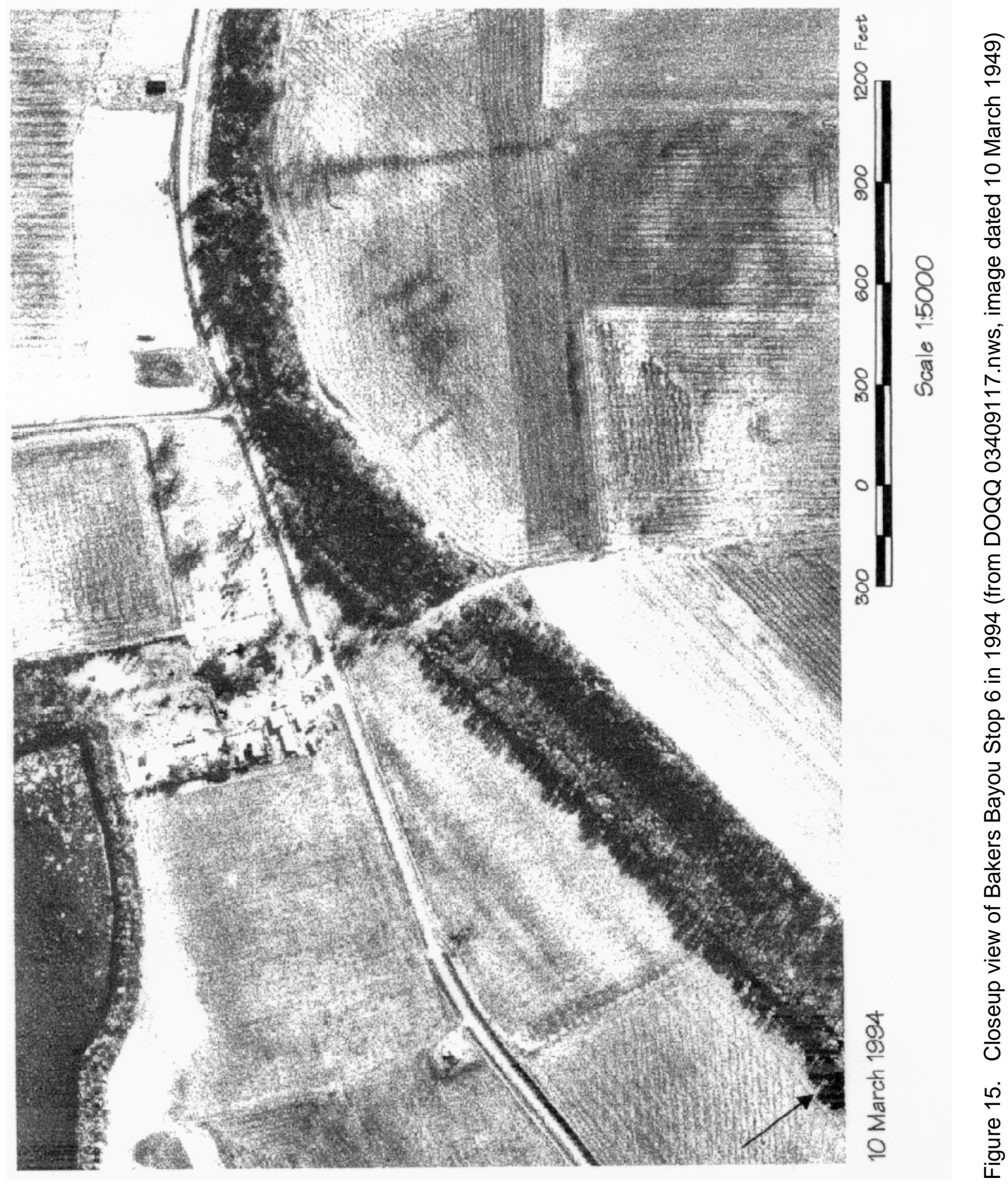


Comparison of these different time periods identifies the vegetation corridor bordering the relic river course at Site 6 as being relatively constant in width during the time interval covered by the photography. However, further upstream and downstream from Site 6, much of the channel area has been clear-cut for farm use (i.e., Figure 3).

Figure 13 highlights a modern-day geomorphic mystery. North and south of Bakers Bayou are several hundred or more rounded, circular, or elliptical hills, between 2 and $3 \mathrm{ft}$ (61 to $91 \mathrm{~cm}$ ) high, and about 30 to $60 \mathrm{ft}$ (9 to $18 \mathrm{~m}$ ) in diameter. These low-relief hills are known as pimple mounds, prairie mounds, or incorrectly as mima mounds. The geomorphic mystery surrounding these mounds involves their origin. There is no widely accepted explanation for their origin. Saucier (1994) suggests that pimple mounds are the result of either ant or termite colonies. More than 20 different theories of origin have been proposed.

Noteworthy to this study from a chronological perspective is that no pimple mound formation by whatever cause has occurred more recently than about 5,000 years before the present (Saucier 1994). The occurrence of pimple mounds along either side of Bakers Bayou supports the age estimate for Bakers Bayou (Figures 8 and 9). The presence of the mounds on the 1937 photography helps to mark the limits of the abandoned course. Historic land use changes in the vicinity of Site 6 are further illustrated by the disappearance (due to human disturbance) of these pimple mounds in the 1994 imagery (Figure 15).

A closer examination of Figures 13 through 15 indicates variable channel conditions between time periods. Figure 13 identifies high-water conditions, as the trees are flooded in 1937. Attention is drawn to the water level in the southwest corner of the photograph and the location marked by the arrow (i.e., location 15, see Figure 12, note channel width in Table 1). At this location, the flooded zone is approximately $206 \mathrm{ft}$ (62.8 m) wide. There is no well-defined channel anywhere on the 1937 photograph in Figure 13. Attention is also drawn to a portion of Bakers Bayou between the two houses in the northeast corner of the photograph. At this location, a well-defined channel is not present in 1937.

Examination of these two locations in the 1949 photo identifies several noteworthy changes. First, the water level is much lower in the 1949 photograph compared with the 1937 time period. Second, a channel has been dug in Bakers Bayou (northeast corner of Figure 14) between the two houses. And, third, a well-defined channel is not present along Bakers Bayou except in the area between Site 6 and the canal. East of the dirt trail that crosses Bakers Bayou at Site 6, the channel is between 40 and $70 \mathrm{ft}$ (12 and $21 \mathrm{~m}$ ) wide.

Figure 15 presents the most recent imagery of Bakers Bayou examined during this study. In this black-and-white satellite image, the water level is low, the tree canopy is less developed than in the preceding time intervals, and a welldefined channel is noticeable for the first time along the northern edge of the bayou. This channel was probably dug to pass water efficiently through this reach. Also noteworthy are the absence of pimple mounds, which were abundant in the 1937 photograph. 


\section{Selected 1854 GLO Survey Locations}

A final comparison of historic survey data and photography is made for representative 1854 GLO survey locations. Figures 16 through 18 present enlargements of photographs for locations 15,16 , and 11, respectively (see Figure 12 for survey locations). The close-ups are intended to see whether the survey data can be matched with the channel conditions on either the 1937 or 1949 photographs, before wide-scale disturbance occurred.

Figure 16 compares the survey data with the historic photography for GLO survey location 15. The center of the photographs in Figure 16 corresponds to the section line intersection with Bakers Bayou. The survey reports a stream width of 100 links or $66 \mathrm{ft}$ (see Table 1). Examination of the 1937 photograph in Figure 16 shows interconnected open-water ponds (darker areas) that are linked together by narrow stream segments. No well-defined channel is present at this location, as previously described. An open pond $66 \mathrm{ft}$ across would best represent channel conditions at this location. Similarly, the channel is poorly defined nearly 100 years after the survey was made as seen on the 1949 photograph.

Figure 17 compares the survey data with the historic photography for GLO survey location 16. At this location, the road crossing the 1937 photograph corresponds to the survey line intersection with Bakers Bayou. The 1854 survey reports a width of 200 links or $132 \mathrm{ft}$ at this location. Here again, the channel area probably corresponds to open ponds, separated by interconnecting, narrow stream segments. The largest open-water area immediately south of the road (section line) would correspond to a width of about $132 \mathrm{ft}$ for comparison purposes with the survey report. In the 1949 photograph, the channel area is much reduced.

Figure 18 compares the survey data with the historic photography for GLO survey location 11. A similar situation occurs at this location. The channel width reported at the time of the survey was 250 links or $165 \mathrm{ft}$. This width corresponds to the flooded area shown in the 1937 photograph.

\section{Soils Data}

Soils and boring data are an essential part of this study to establish the vertical limits of the historic channel fill. Published USDA (1981) soils data identify unique soil series associated with the old Bakers Bayou course and with the natural levees bordering the old channel. Within the old channel are the Keo silt loam and Perry silt clay, and associated with the natural levees are the Herbert silt loam and Rila silt loam. Typical profiles for these different soil series are presented in Appendix E. 

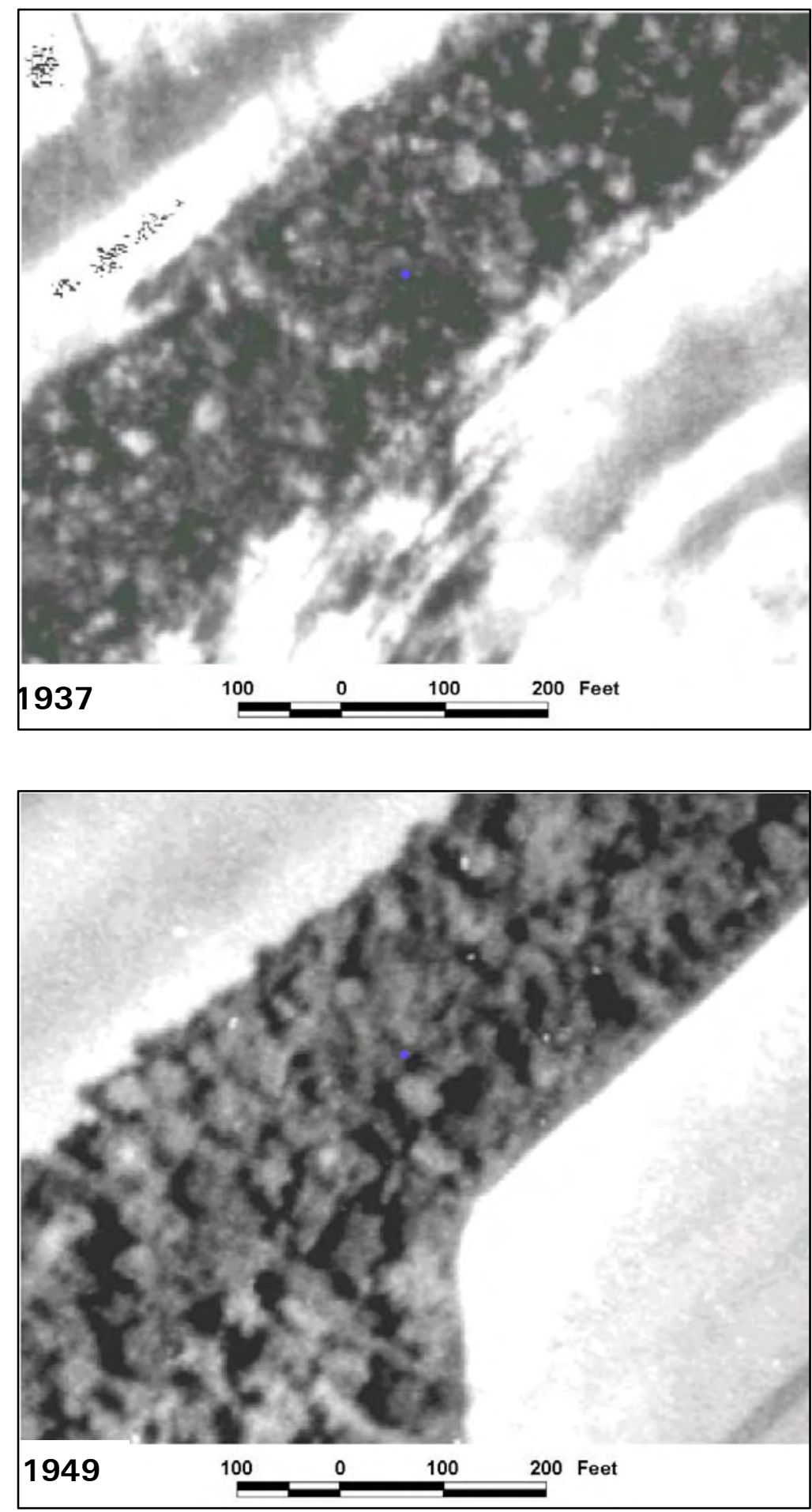

Figure 16. Location 15 from GLO 1854 survey (see Figure 12 and Table 1). Channel width at time of survey was 100 links or $66 \mathrm{ft}$. Center of photo marks section line intersection with Bakers Bayou 

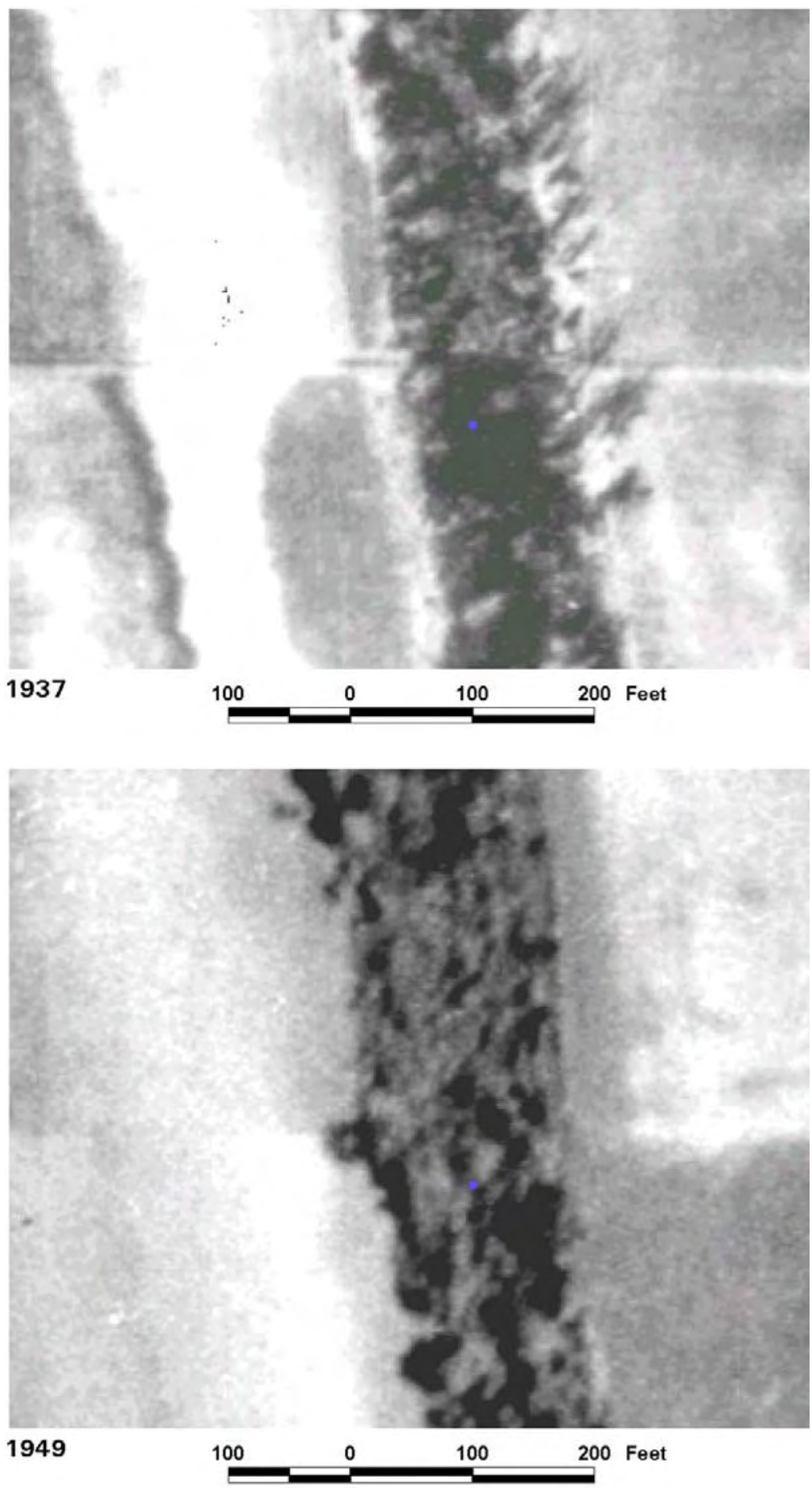

Figure 17. Location 16 from GLO 1854 survey (see Figure 12 and Table 1). Channel width at time of survey was 200 links or $132 \mathrm{ft}$. Road across Bakers Bayou in 1937 photo approximates intersection of bayou with section line. Width of bayou at road in 1937 corresponds closely to survey width 

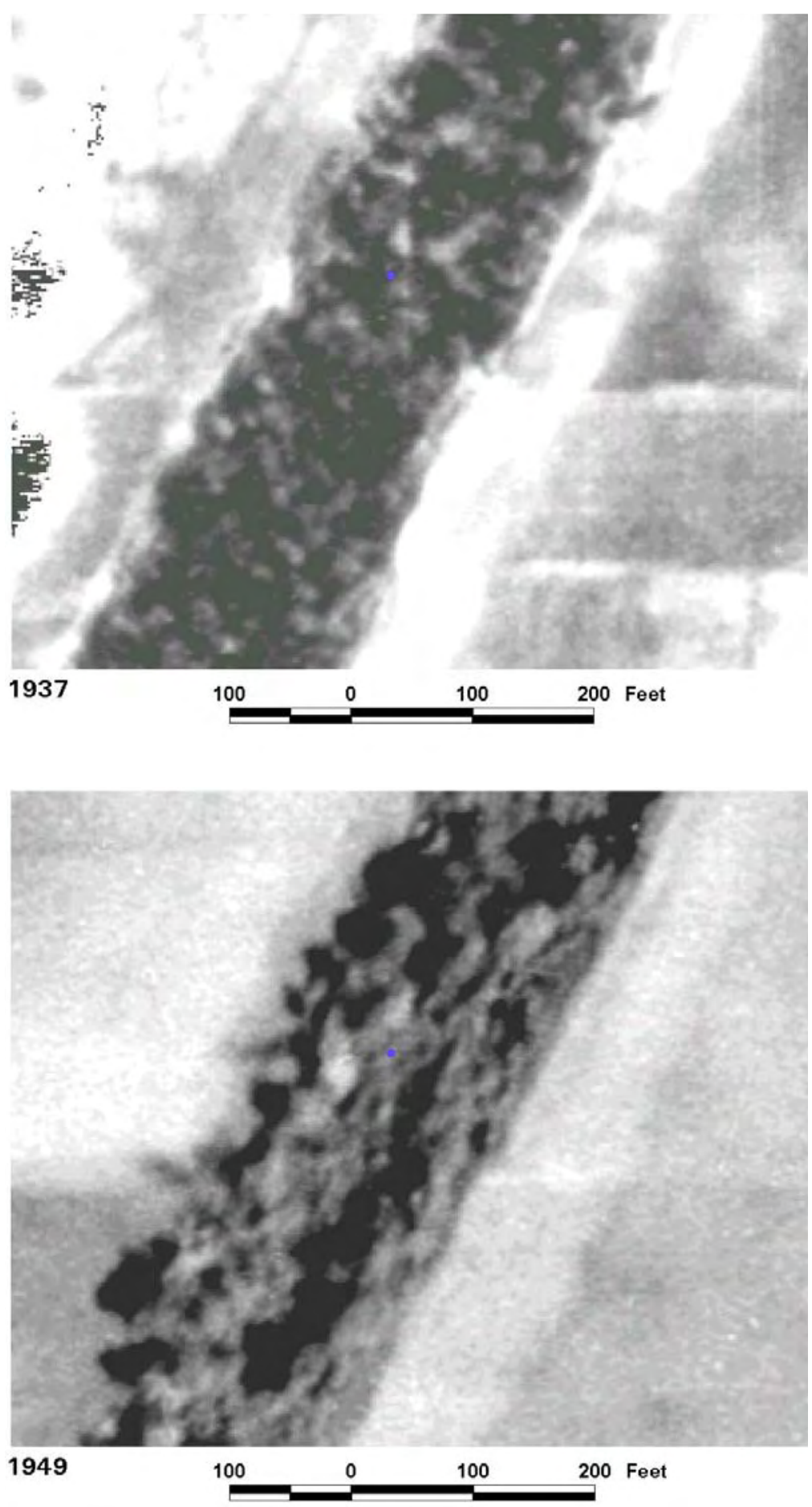

Figure 18. Location 11 from GLO 1854 survey (see Figure 12 and Table 1). Channel width at time of survey was 250 links or $165 \mathrm{ft}$. Center of the photo approximates section line intersection with Bakers Bayou. Width of flooded channel in 1937 photo corresponds closely to width of 1854 channel 
Soils data in Appendix E identify the edges of the old channel as being composed of Keo silt loam (USCS equivalent to CL - ML). In contrast, the soils along the lower elevations of the old channel, which corresponds to the location of the present bayou, are generally composed of Perry silt clay (USCS equivalent to $\mathrm{CH}$ ). Both soil series include a buried soil horizon, which contains small carbonate concretions. Mottling is abundant in the Perry silt clay, and nearly absent in the Keo silt loam.

Natural levee soils are composed of the Herbert silt loam and the Rilla silt loam. These soil series correspond to a ML-CL in the USCS. Mottling is common. No buried soil horizons are associated with these soil series. However, both of these soils contain a well-developed argillic (t) B horizon (Appendix E). An argillic horizon corresponds to a B horizon with greater amounts of clay relative to the $\mathrm{A}$ or $\mathrm{C}$ horizon. The significance of an argillic horizon from a geomorphic perspective is that the clay has been illuviated or transported from the A horizon to the B horizon in solution. The increase in the clay content implies a stable horizon that through time has developed an argillic (Bt) horizon.

Soil characteristics are an important diagnostic tool to this study. A key question to this study is the significance of the buried soil horizon within the Keo and Perry soils. Does this buried soil contact mark the transition between natural conditions (i.e., prehistoric) and the onset of agriculture activities by European man in the region? If this theory is correct, then the cause for the buried horizon is associated with regional deforestation, increased surface runoff, and increased sediment transport to the drainage network. Alternatively, the buried soil horizon may represent a boundary caused by climatic changes, or a major course shift in the Arkansas River, whereby increased flooding and sediment are associated with closer proximity to the active river.

\section{Boring Data}

Six borings were drilled at Site 6 for this study to examine the soils and the stratigraphic characteristics of the upper channel fill (see Appendix A for boring logs and Figure 5 for boring locations). The lithology of the upper channel fill consists mostly of silt (ML) and clay (CL). Soil color is highly variable, ranging from grey to tan, brown, yellow brown, and orange brown. Iron and manganese mottles are present throughout most of the core samples examined. Mottles range from few ( $<2$ percent surface area) to many ( $>20$ percent surface area). Also present are a few small iron and carbonate concretions. Bedding typically ranges from thin beds to fine lamina, with both horizontal and cross bedding forms present. Bedding is visible in about half the length of core examined and is generally associated with the lower half of the borings where sedimentation rates were much higher. Bioturbation has generally destroyed most of the shallow primary sedimentary structures. Organic materials have typically been oxidized or reduced and are present as fine lamina (i.e., <1/16-in., 1.6-mm) and/or disseminated organics. No significant occurrences of wood fragments, peat layers, or highly organic zones were present within the upper, fine-grained channel fill at Site 6. 
The absence of large wood fragments and/or thick occurrences of interbedded organic materials within the upper part of the abandoned course fill is the result of oxidation and reduction of these sediments. Both of these processes generally consume most of the organics that are within the soil. The presence of mottles or redoximorphic features reflects the complex interplay between seasonal soil saturation, oxidation, reduction, and bacteria decomposing organic matter under anaerobic and aerobic conditions. The chemical process whereby mottles are produced and form iron masses, nodules, and concretions, or iron depletions and grey zones within the soil profile, is described in detail by Vepraskas (1999). Redoximorphic features are most abundant in the cores from the center of the abandoned Bakers Bayou course, and become less pronounced along the margins of the old channel.

A detailed geologic cross section from the Bakers Bayou borings is presented in Figure 19 and identifies the major subdivision of the old channel from stratigraphic information. The boring logs in Appendix A identify laminated intervals and zones where bedding is absent because of bioturbation by organic activity. Laminated bedding corresponds to pulses of new sediment deposition during annual flooding. During the latter stages of filling of the Bakers Bayou abandoned course, accumulation of new sediment was probably restricted to major floods (i.e., 25-, 50-, 100-year events), when floodwaters were able to extend into and partially fill the old course and transport new sediment. In between these major events, pedogenic activity would have altered or destroyed primary depositional structures depending on the time interval between flood events.

Available boring data from the center of the channel indicate a possible buried soil horizon between 1.0 and $1.5 \mathrm{ft}$ (30 to $45 \mathrm{~cm}$ ). A piece of glass was present in BB-5 at $1.2 \mathrm{ft}(37 \mathrm{~cm})$, and a possible buried Ao horizon was present in BB-2 at $1.5 \mathrm{ft}(45 \mathrm{~cm})$.

\section{Sedimentation Rates}

Radiometric dating was utilized in BB-4 to establish a chronology to calibrate the stratigraphy and soils data. Table 2 summarizes the results of the different methods used to age date sediments from boring BB-4.

\section{Table 2}

Summary of Radiometric Dating of Samples from BB-4

\begin{tabular}{||l|l|l|l||}
\hline \hline Depth, cm (in.) & Dating Method & Reported Age & Calculated Sed Rate \\
\hline \hline $0-2 \mathrm{~cm}(0-0.78$ in.) & Cs-137 & $<1950$ & $0.04 \mathrm{~cm} / \mathrm{yr}$ \\
\hline $14 \mathrm{~cm}(5.5$ in. $)$ & $\mathrm{Pb}-210$ & $151 \mathrm{yrs}$ & $0.09 \mathrm{~cm} / \mathrm{yr}$ \\
\hline $167-208 \mathrm{~cm}(66-82.2$ in.) & $\mathrm{C}-14$ & $1540 \mathrm{yrs}$ & $0.11-0.14 \mathrm{~cm} / \mathrm{yr}$ \\
\hline
\end{tabular}

Included in Table 2 are sedimentation rates based on various age-dating methods. A bulk soil sample was necessary for the C-14 dating due to the absence of wood fragments and organic rich soil horizons. The bulk sample was 


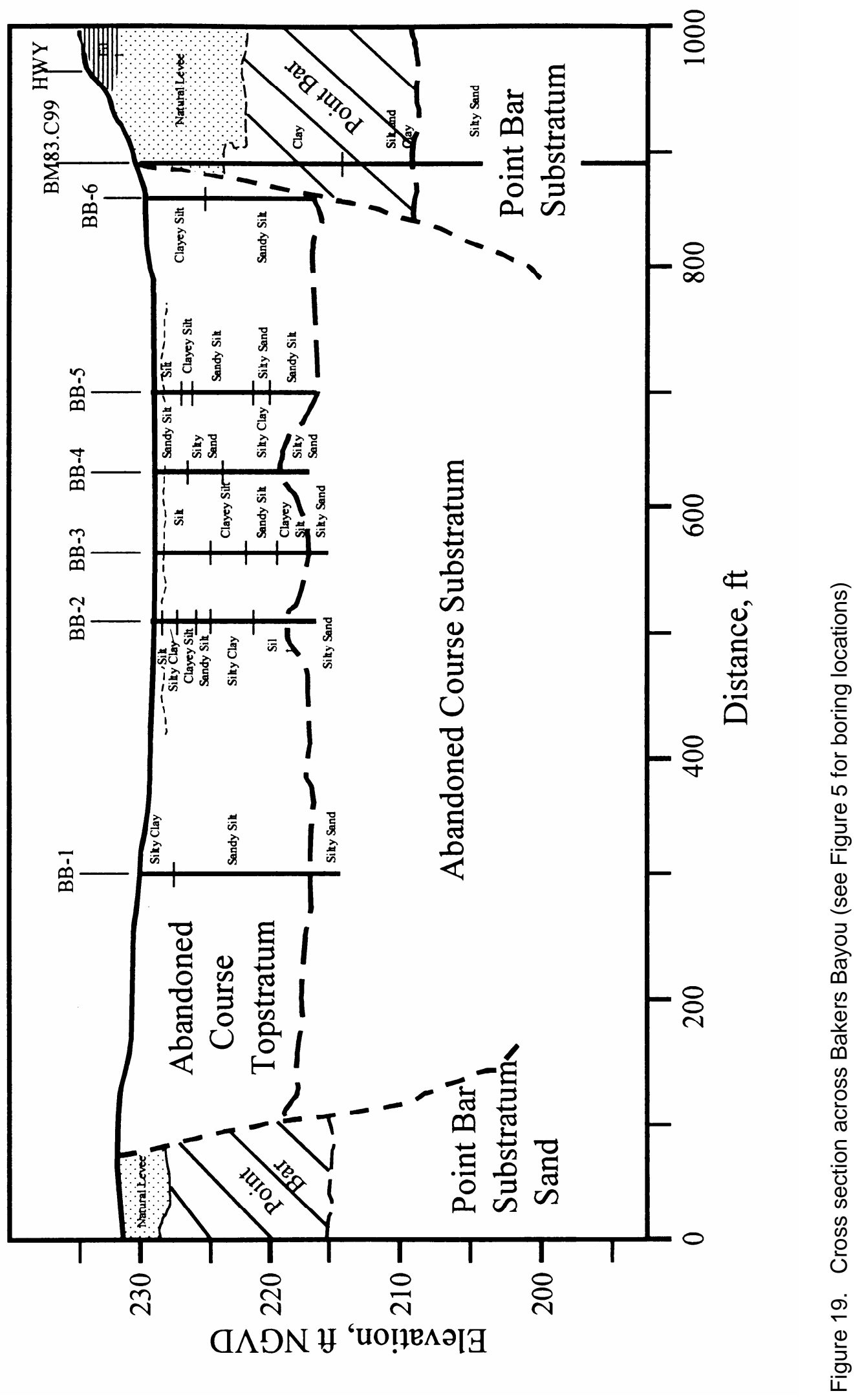


dated using accelerator mass spectrometry (AMS) techniques. The C-14 based sedimentation rate is between 0.11 and $0.14 \mathrm{~cm} /$ year, and represents the rate of filling between the depth intervals 14 and $167 \mathrm{~cm}$ and 14 and $208 \mathrm{~cm}$, respectively. An average value representing the midpoint for this interval corresponds to a rate of $0.125 \mathrm{~cm} / \mathrm{yr}$. The $\mathrm{C}-14$ and lead- 210 methods provide similar results and compare favorably. Both the short-term ( 150 years) and long-term $(\sim 1,500$ years) rates are in agreement. The presence of a glass fragment at $1.2 \mathrm{ft}(37 \mathrm{~cm})$ in core BB-5 provides a maximum sedimentation rate of $0.25,0.37$, or $0.74 \mathrm{~cm} /$ year based on the glass being 150,100 , or 50 years old, respectively.

\section{Buried Keo and Perry Soils as Historic Marker Horizons}

In an earlier section of this chapter, it was reported that buried soils are associated with the Keo and Perry soil series (Appendix E) and that these soils were characteristic of the abandoned Arkansas River course known as Bakers Bayou. A major question raised was whether there is a relationship between historic land-use changes and the burial of these soil surfaces. Based on the average long-term sedimentation rate determined from this study, it is possible to test whether buried soil horizons identified for Keo and Perry soils are related to historic land-use changes.

The typical depth reported for buried soils associated with the Bakers Bayou course is more than $36 \mathrm{in}$. $(92 \mathrm{~cm})$ as shown by the profiles in Appendix E. The estimated time required to bury a soil to a depth of 36 in. $(92 \mathrm{~cm})$ using the average sedimentation rate of $0.125 \mathrm{~cm} /$ year is 736 years. This estimate indicates that these buried soils are not related to historic land-use changes.

Additional information was provided by Mr. Tom Fortner (personal communication). Mr. Fortner was for many years the Lonoke County District Conservationist, Natural Resources Conservation Service, Lonoke, AR. He considered the buried soils in Bakers Bayou to be much older and, consequently, not associated with or related to historic land-use changes. Furthermore, he indicated that the Perry soils were incorrectly mapped in Bakers Bayou. These soils should have been assigned a new soil series. Instead, they were assigned to the Perry series because of their high clay content. 


\section{Conclusions and Recommendations}

Several data sets were gathered and analyzed during this study to determine the prehistoric channel limits along Bakers Bayou at Site 6. The time frame of particular interest to this study is 1850 because man-made impacts to the floodplain would have been negligible. From the data examined during this study, the following conclusions are presented.

a. Bakers Bayou is an abandoned Arkansas River Course that was active between 6,000 and 8,000 years before the present.

b. Maximum channel width along Bakers Bayou during the Middle Holocene was between 600 and $900 \mathrm{ft}$. Maximum channel width at Site 6 is about $710 \mathrm{ft}(216 \mathrm{~m})$.

c. Historic survey data identifies an 1850 channel along Bakers Bayou as ranging from 66 to $231 \mathrm{ft}$ ( 20 to $70 \mathrm{~m}$ ) wide. Maximum channel width at Site 6 is estimated to range from 60 to $120 \mathrm{ft}$ (18 to $37 \mathrm{~m}$ ) based on 1937 photography. Available data examined for this study indicate the typical channel through the Bakers Bayou reach was probably not a single main channel, but rather a series of open to forested ponds separated by short and narrow channel segments.

d. Radiometric dating of sediment samples from boring BB-4 indicates general agreement between short term ( 150 years) and long-term ( $\sim 1,500$ years) sedimentation rates. The range in rates varies between 0.04 and $0.14 \mathrm{~cm} /$ year. An average sedimentation rate of $0.125 \mathrm{~cm} /$ year is considered representative of long-term, prehistoric conditions. A piece of glass in boring BB-2 at $1.2 \mathrm{ft}(37 \mathrm{~cm})$ indicates the historic rates may be as high at $0.74 \mathrm{~cm} /$ year, assuming a glass age of 50 years.

e. The historic channel depth for Bakers Bayou at Site 6 is estimated at less than $1 \mathrm{ft}(<30 \mathrm{~cm})$. A probable maximum depth would be estimated at no more than $3 \mathrm{ft}(<1 \mathrm{~m})$.

The following recommendation is made: 
Perform additional shallow sampling and dating to verify the estimate of sedimentation rates in both disturbed and nondisturbed areas along Bakers Bayou. From the results of this study, the recommended sample depth would be no more than $5 \mathrm{ft}(1.5 \mathrm{~m})$. Sampling should be performed at four other locations to establish the sedimentation rates and historic filling for the entire reach of the project area. 


\section{References}

Dunbar, J. B. (2001). “Bakers Bayou Field Trip, Lonoke, AR,” Trip Report, Engineer Research Development Center, U.S. Army Engineer Research and Development Center, Vicksburg, MS.

Saucier, R. T. (1964). “Geologic Investigation of the St. Francis Basin,” Technical Report No. 3-659, U.S. Army Engineer Waterways Experiment Station, Vicksburg, MS.

Saucier, R. T. (1967). "Geologic Investigation of the Boeuf-Tensas Basin, Lower Mississippi Valley,” Technical Report No. 3-757, U.S. Army Engineer Waterways Experiment Station, Vicksburg, MS.

Saucier, R. T. (1994). "Geomorphology and Quaternary Geologic History of the Lower Mississippi Valley,” U.S. Army Corps of Engineers, Mississippi River Commission, Vicksburg, MS.

USAE Waterways Experiment Station. (1951). "Geology of the Lower Arkansas River Alluvial Valley,” Technical Report 3-332, Vicksburg, MS.

U.S. Army Corps of Engineers. (1996). Soil Sampling, Engineer Manual 11101-1906, Washington, DC.

U.S. Department of Agriculture. (1981). "Soil Survey of Lonoke and Prairie Counties, Arkansas,” U.S. Department of Agriculture, Soil Conservation Service, Washington, DC.

Vepraskas, M. J. (1999). "Redoximorphic Features for Identifying Aquic Conditions,” Technical Bulletin 301, North Carolina Agricultural Research Service, North Carolina State University, Raleigh, NC. 


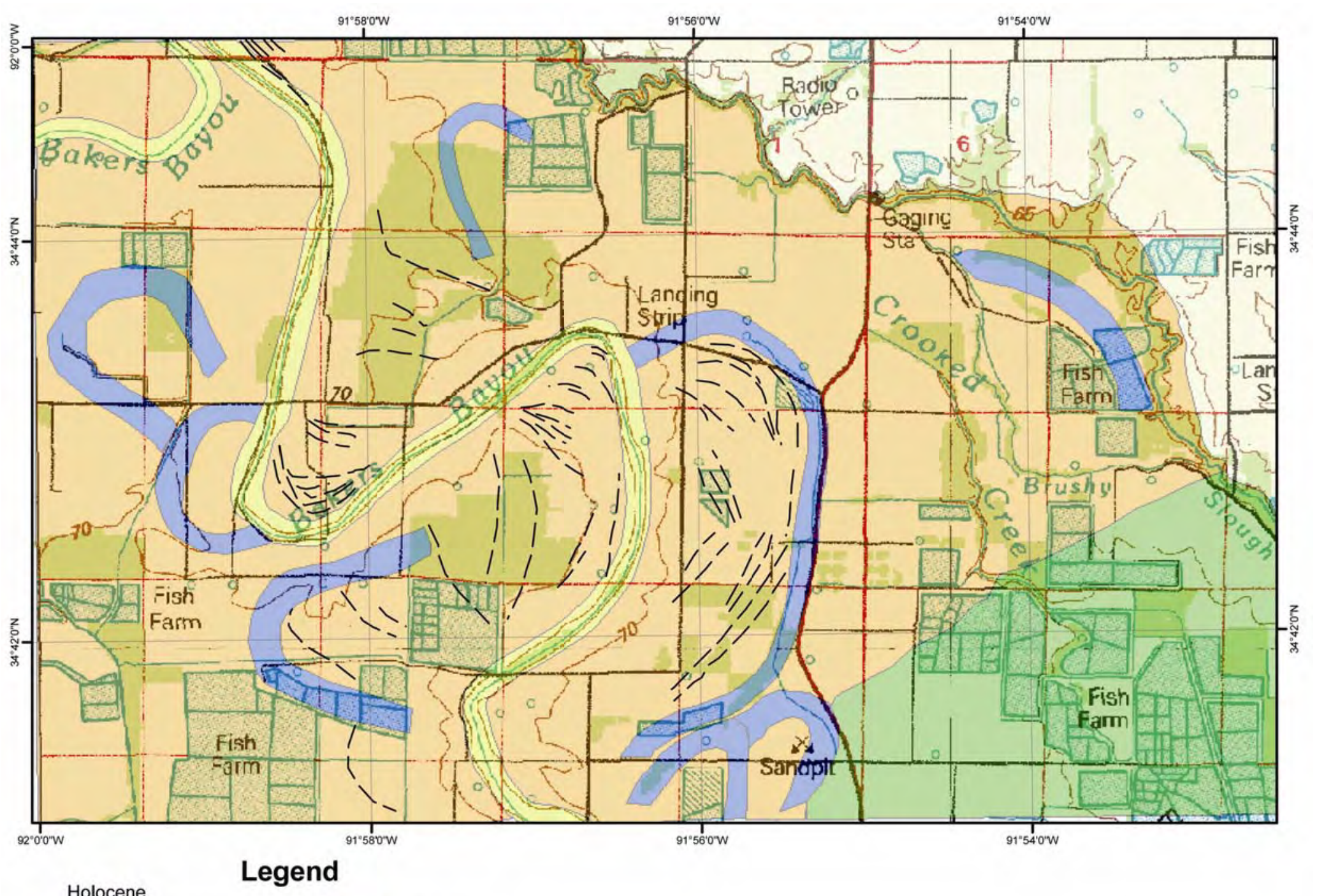

Holocene

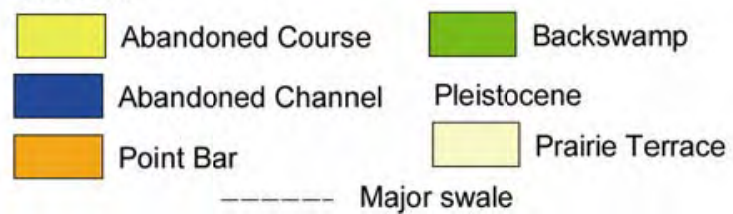

Plate 1

Bakers Bayou Geomorphic Map 


\section{Appendix A Soil Boring Logs}




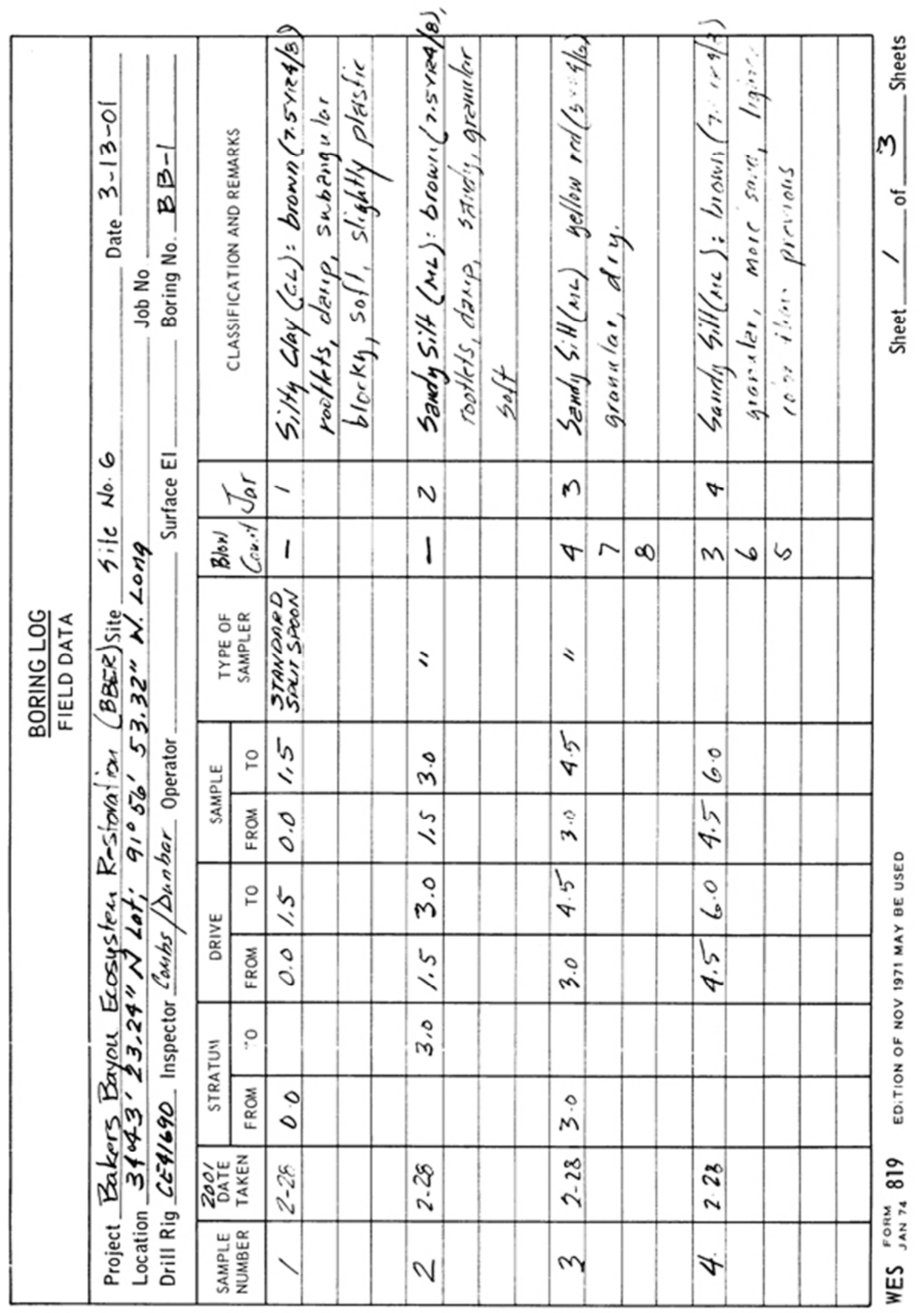




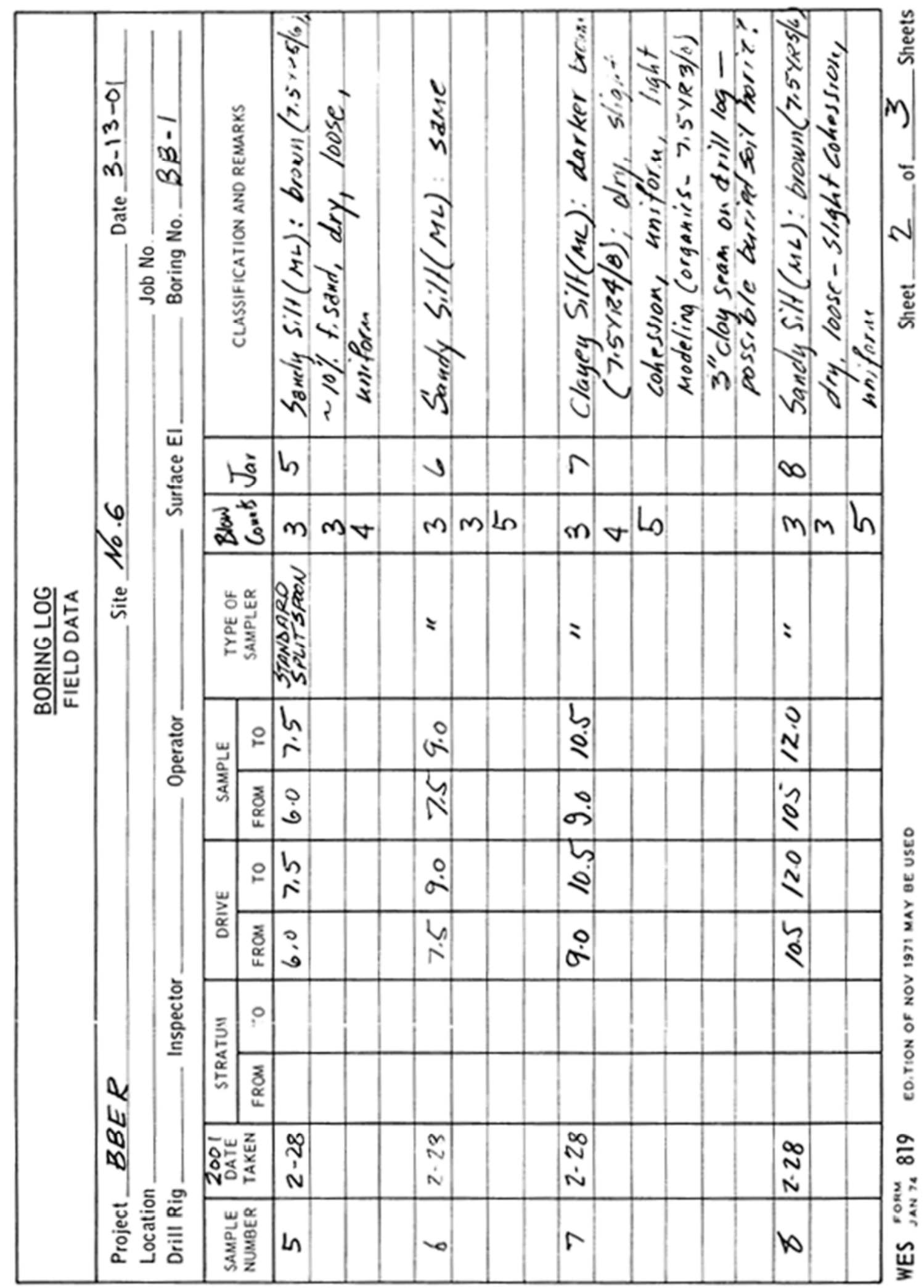




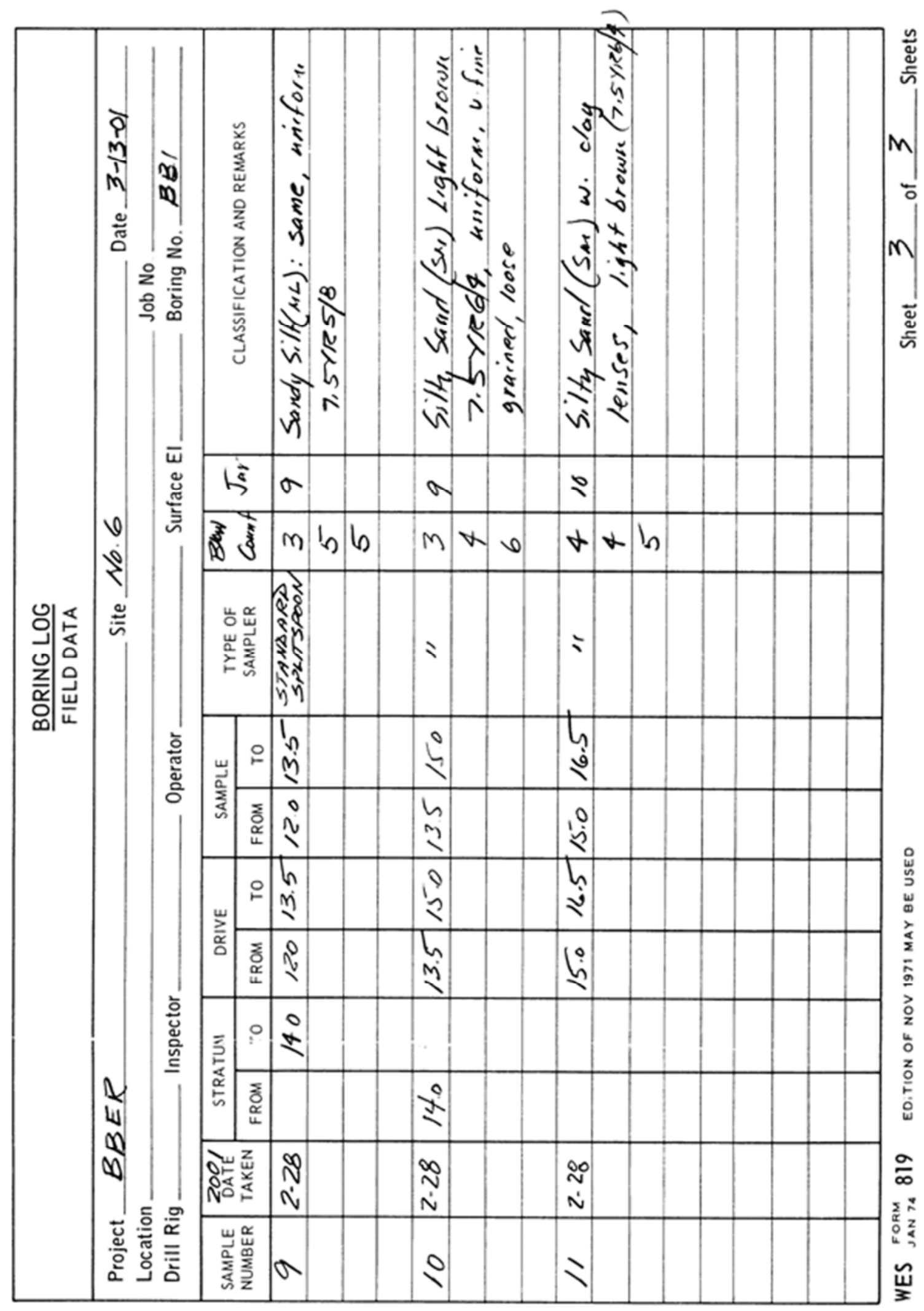


General - SS

\section{FIELD BORING LOG}

$1-B B G-\cdots 1$

HOLE NO.

PROJECT BaKe', Bayeu LOCATION

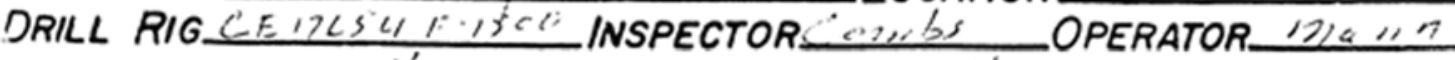
DEPTH OF WATER Nin : DATE TABLE NOME DATE ELEVATION OF GROUND.

\begin{tabular}{|c|c|c|c|c|c|c|}
\hline $\begin{array}{l}\text { Somole } \\
\text { wember }\end{array}$ & Dote & $50 \pi$ & ple & strot & & Clossification_Remorks \\
\hline 1 & $2 \cdot 3 r^{\prime} 11$ & c.e & i). 5 & $\because, \ldots$ & & is istock \\
\hline 2 & . & 1,5 & 3.6 & $b \cdot$ & $3.6^{\circ}$ & 1. \\
\hline 3 & . & $3 \cdot 6$ & 9.5 & 3. 0 & & 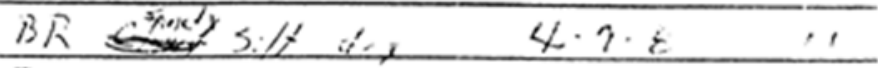 \\
\hline 尘 & 11 & 45 & 6.6 & & & $B K$ S n... S:H \\
\hline 5 & II & $6 c$ & 17.5 & & & $B R \quad S_{\text {ien }} d_{y} S_{i} / \mathrm{t}$ \\
\hline$\underline{l}$ & 11 & 7.5 & 96 & & & $B R$ sine, $5 / 4$ \\
\hline 7 & 19 & 9.0 & k.5. & & & 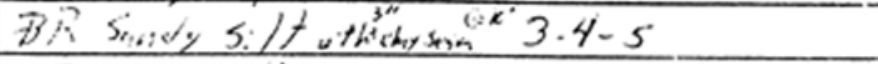 \\
\hline$\varepsilon$ & .1 & k. S & $12 . C$ & & & 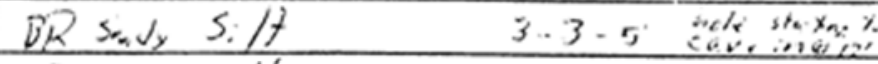 \\
\hline í & it & $1 / 20$ & 13.5 & & $14 / 0$ & $B R \leq n .1,5: 1 / \quad 3.5 .5$ \\
\hline 10 & t & 13.5 & 15.6 & 14. & & 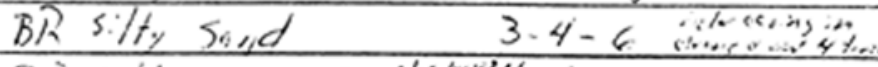 \\
\hline Ll & "- & 15. & $1 / 6.5$ & & 16.5 & 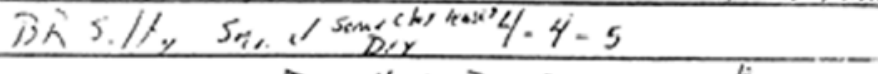 \\
\hline & & 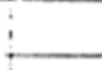 & & & & 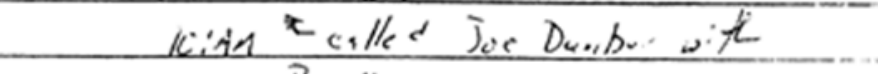 \\
\hline & & $!$ & & & & 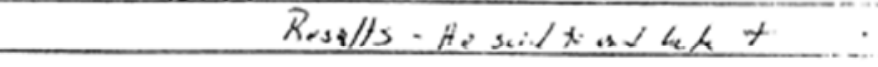 \\
\hline & & $!$ & & & & 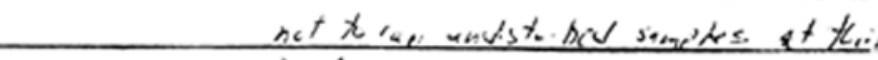 \\
\hline & & & & & & localin \\
\hline & & 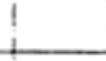 & & & & Corblitys \\
\hline & & $!$ & & & & \\
\hline & $\vdots$ & $!$ & & & & \\
\hline & & $i$ & i & & & \\
\hline & & $!$ & & & & \\
\hline & & 1 & & & & \\
\hline & & & & & & \\
\hline & - & & & & & \\
\hline & & & & & & \\
\hline & & & & & & \\
\hline C5tits & & & & & & \\
\hline JUN & 90 REV & & & & & \\
\hline
\end{tabular}




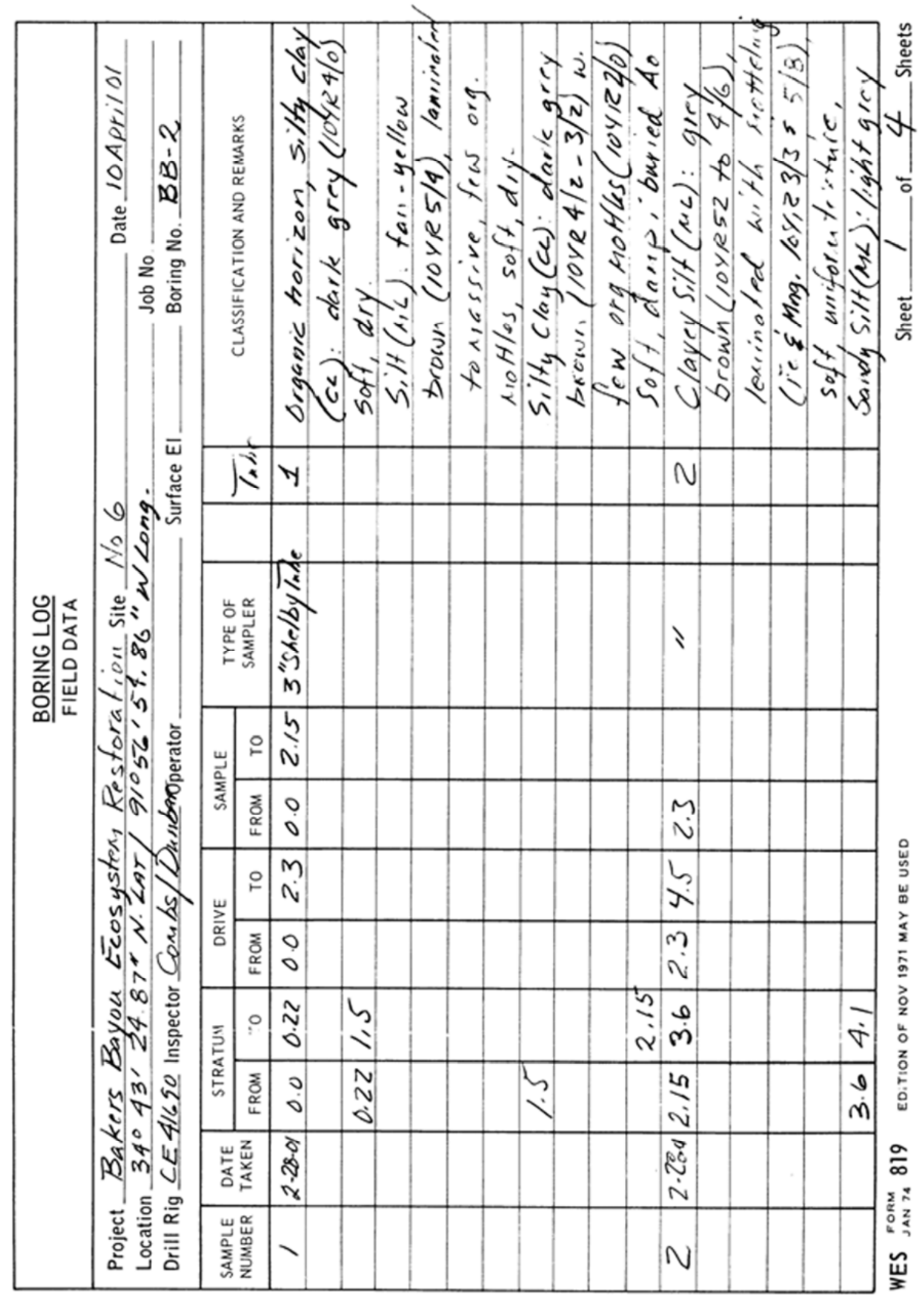




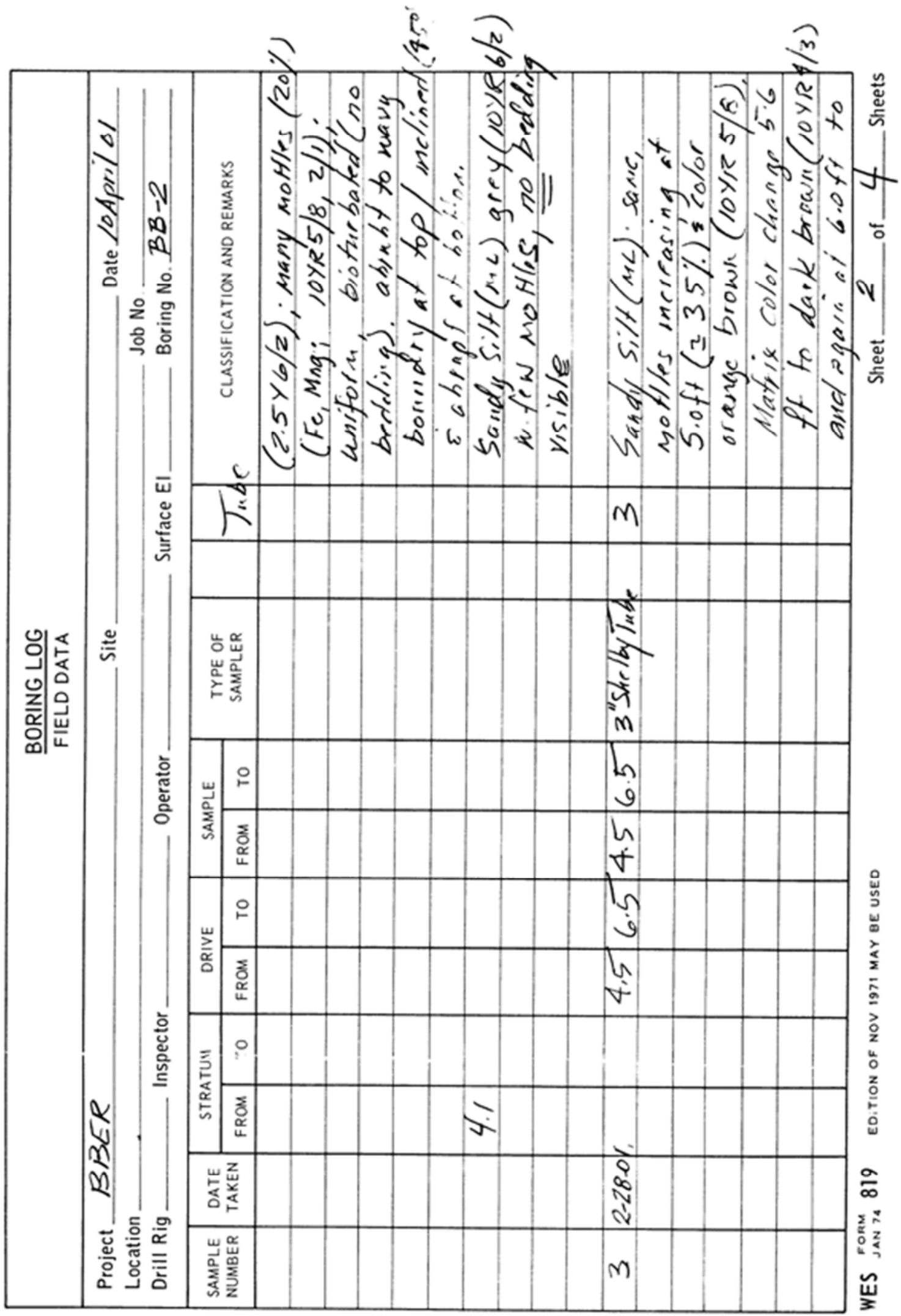




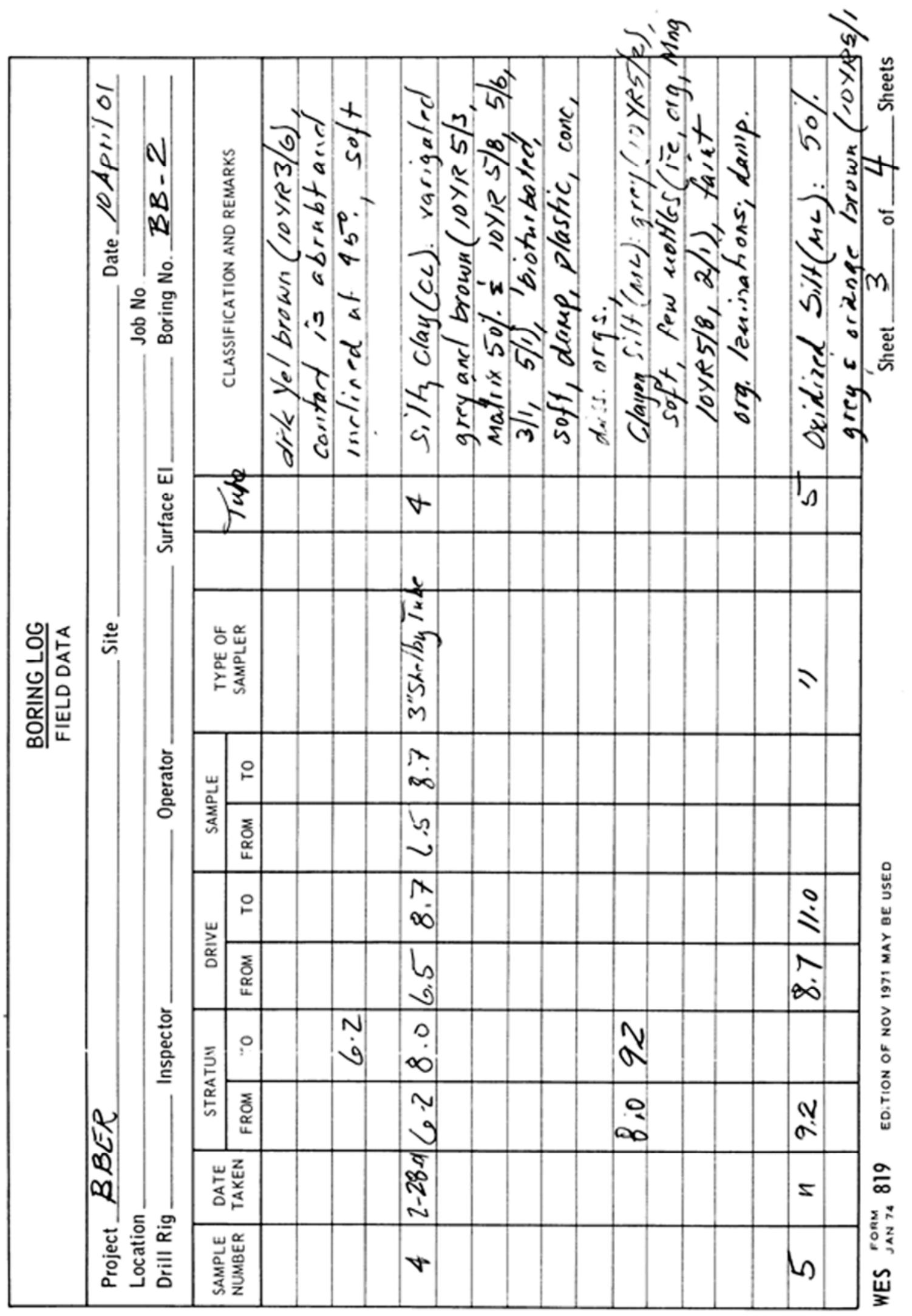




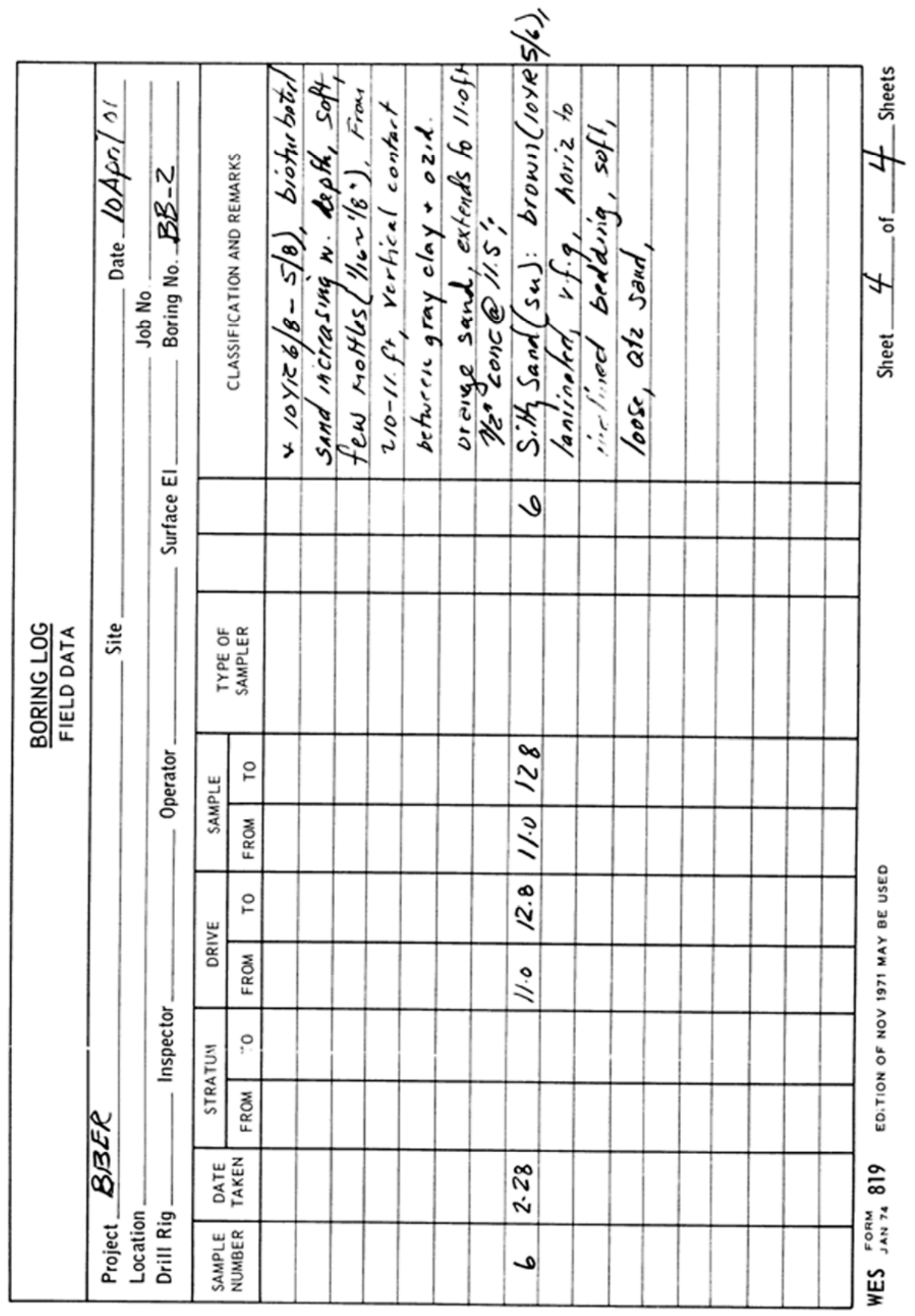




$$
\text { undistuibed \#2 }
$$

\section{FIELD BORING LOG}

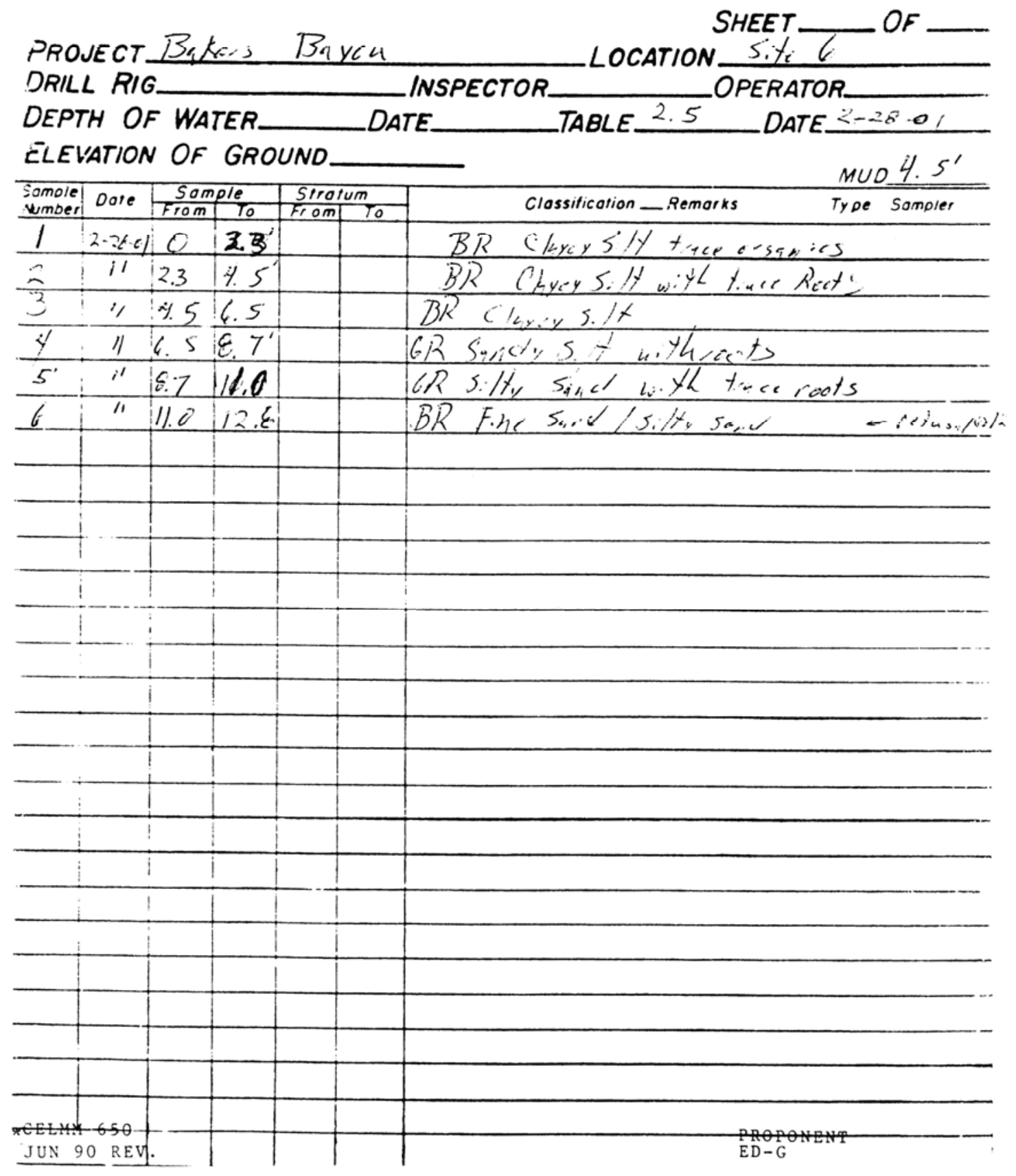




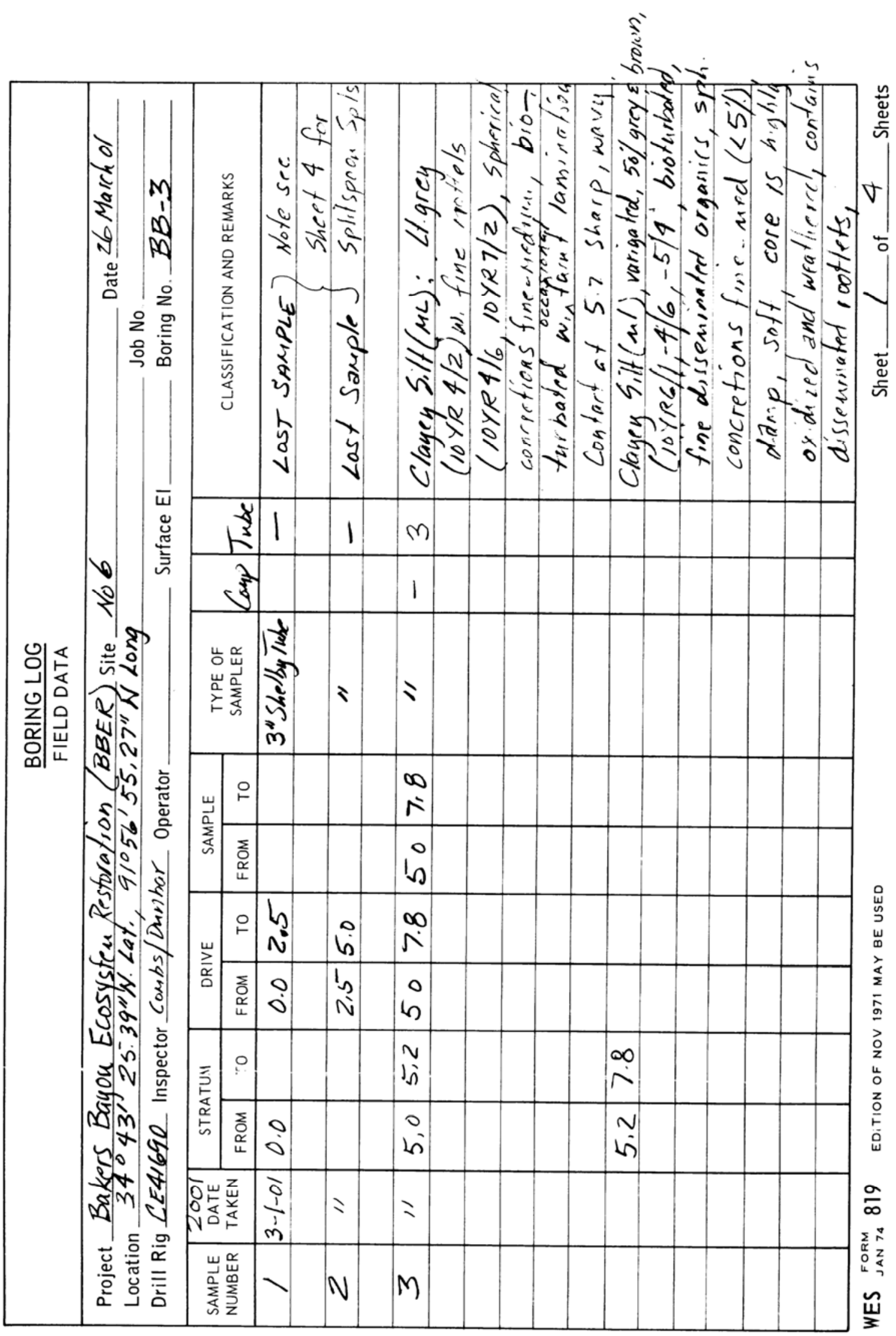




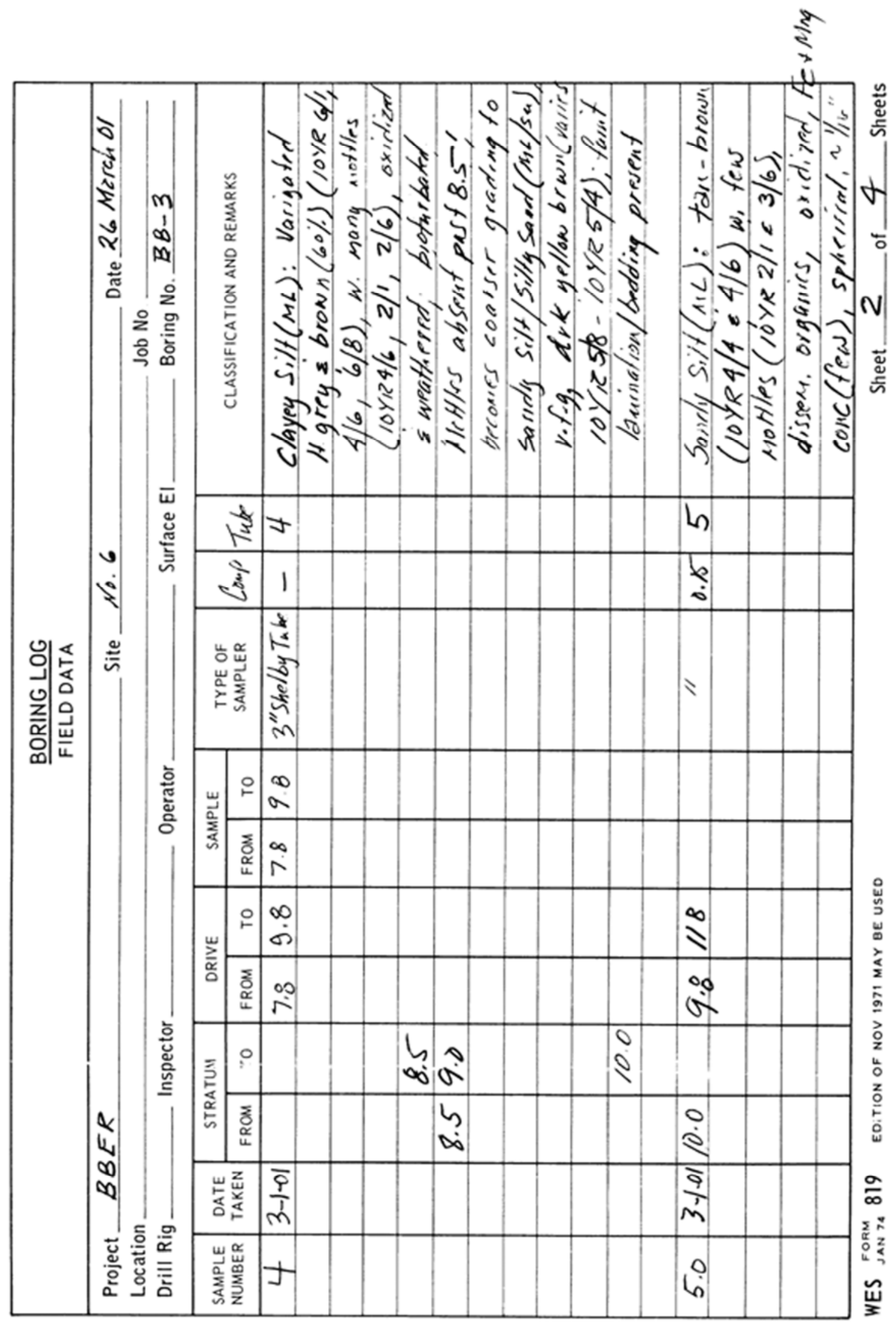




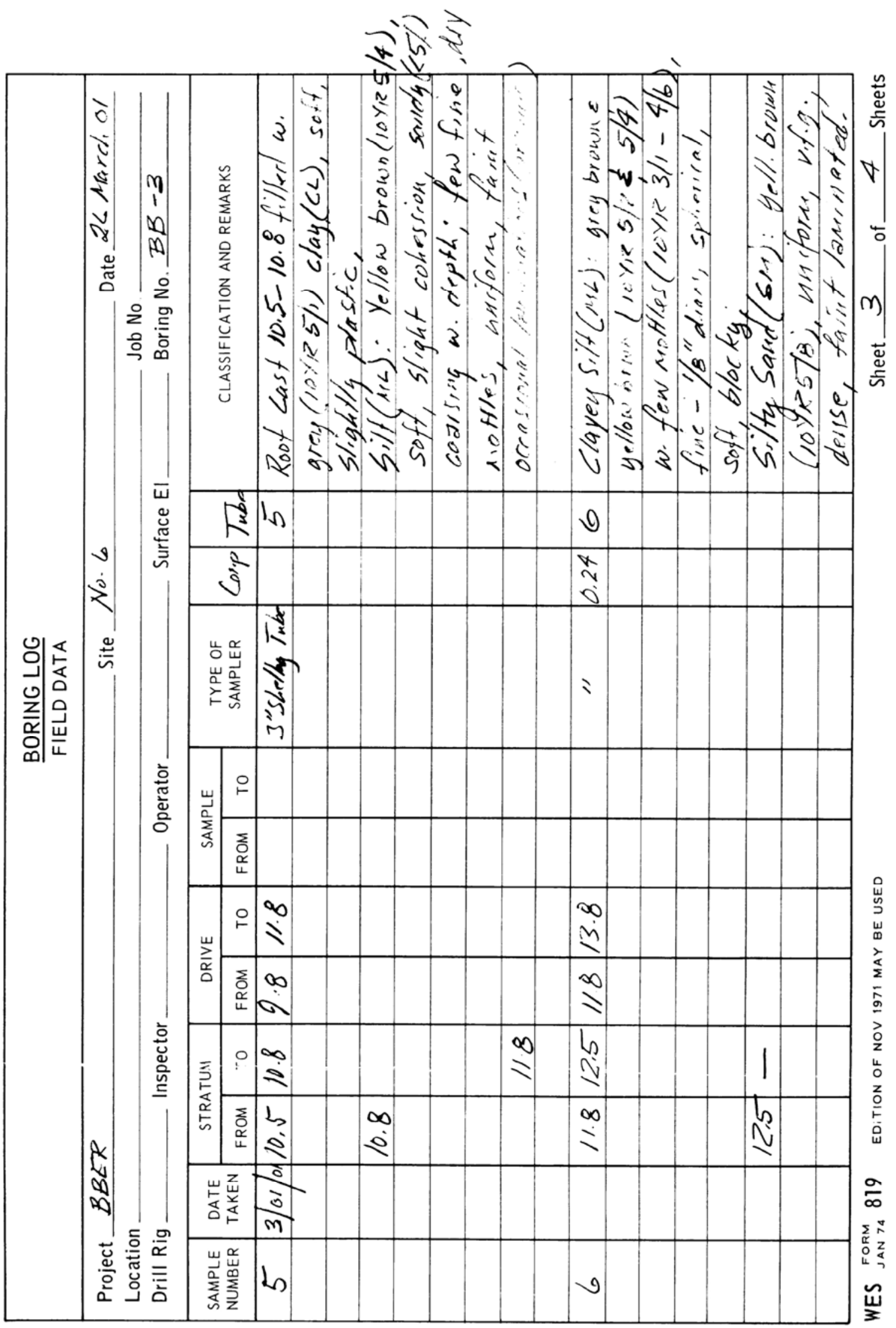




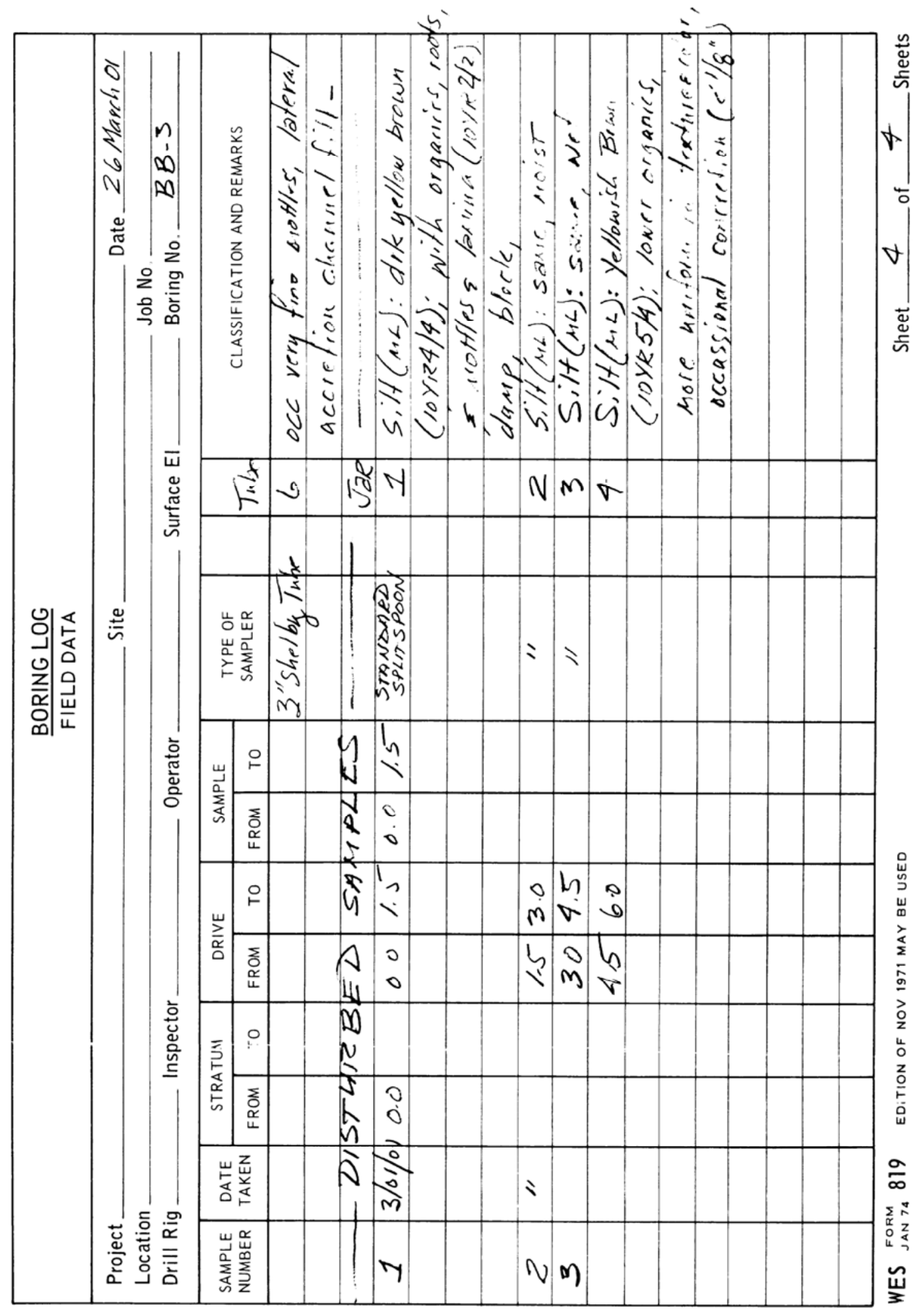




\section{Undistuebed \\ $\# 3$}

FIELD BORING LOG

$3-6 B C L-O 1$

HOLE NO.

PROJECT BaKEIS Baye

SHEET

OF

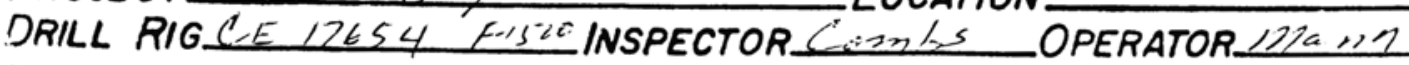
DEPTH OF WATER _ DATE ELEVATION OF GROUND

\begin{tabular}{|c|c|c|c|c|c|c|c|}
\hline Somole & Date & $5 a m$ & ple & Strat & & Classitication Remarks & $m e x+3$ \\
\hline 1 & & ifrom & $\frac{10}{10}$ & From & To & tyoe & Sampler \\
\hline$\frac{1}{n}$ & $3 \% .61$ & 6,0 & -5 & & & 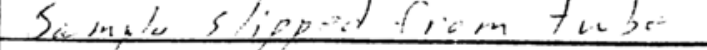 & $3 \%$ \\
\hline 2 & $\cdots$ & 2.5 & 5,2 & & &,$\ldots$ & $\ldots$ \\
\hline 3 & 1 & 5,6 & $7, \varepsilon$ & & & 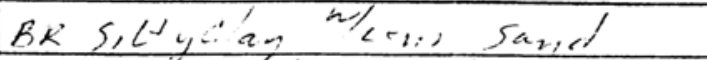 & " \\
\hline 4 & . & 7.8 & ip. \& & & & 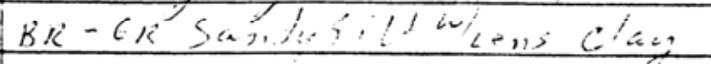 & 1 \\
\hline 5 & 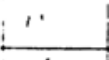 & $q, \varepsilon$ & $11 \%$ & & & $B K$ Silty Sand & $\therefore$ \\
\hline$L$ & $L^{\prime}$ & 11,8 & 13,8 & & & $B K \sin \left(1, S_{2} e_{2} d\right.$ & 1 \\
\hline & & & & & & & \\
\hline & & & & & & & \\
\hline & & & & & & & \\
\hline & & & & & & & \\
\hline Nox & & Missi & $\operatorname{lng}$ & \& se & mple & $2 \not 1 \varepsilon 2$ & \\
\hline & & 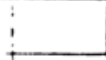 & & & & ' & \\
\hline & & $!$ & & & & & \\
\hline & & 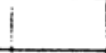 & & & & & \\
\hline & & & & & & & \\
\hline & & & & & & & \\
\hline & & 1 & & & & & \\
\hline & 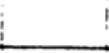 & $!$ & & & & & \\
\hline & & 1 & ! & & & & \\
\hline & & $!$ & & ! & & & \\
\hline & & 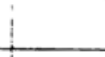 & & & & & \\
\hline & & & & & & & \\
\hline & & & & & & & \\
\hline & & & & & & & \\
\hline & & & & & & & \\
\hline ant & 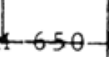 & & & & & & \\
\hline JUN & $90 \mathrm{REV}$ & & & & & Non & \\
\hline
\end{tabular}




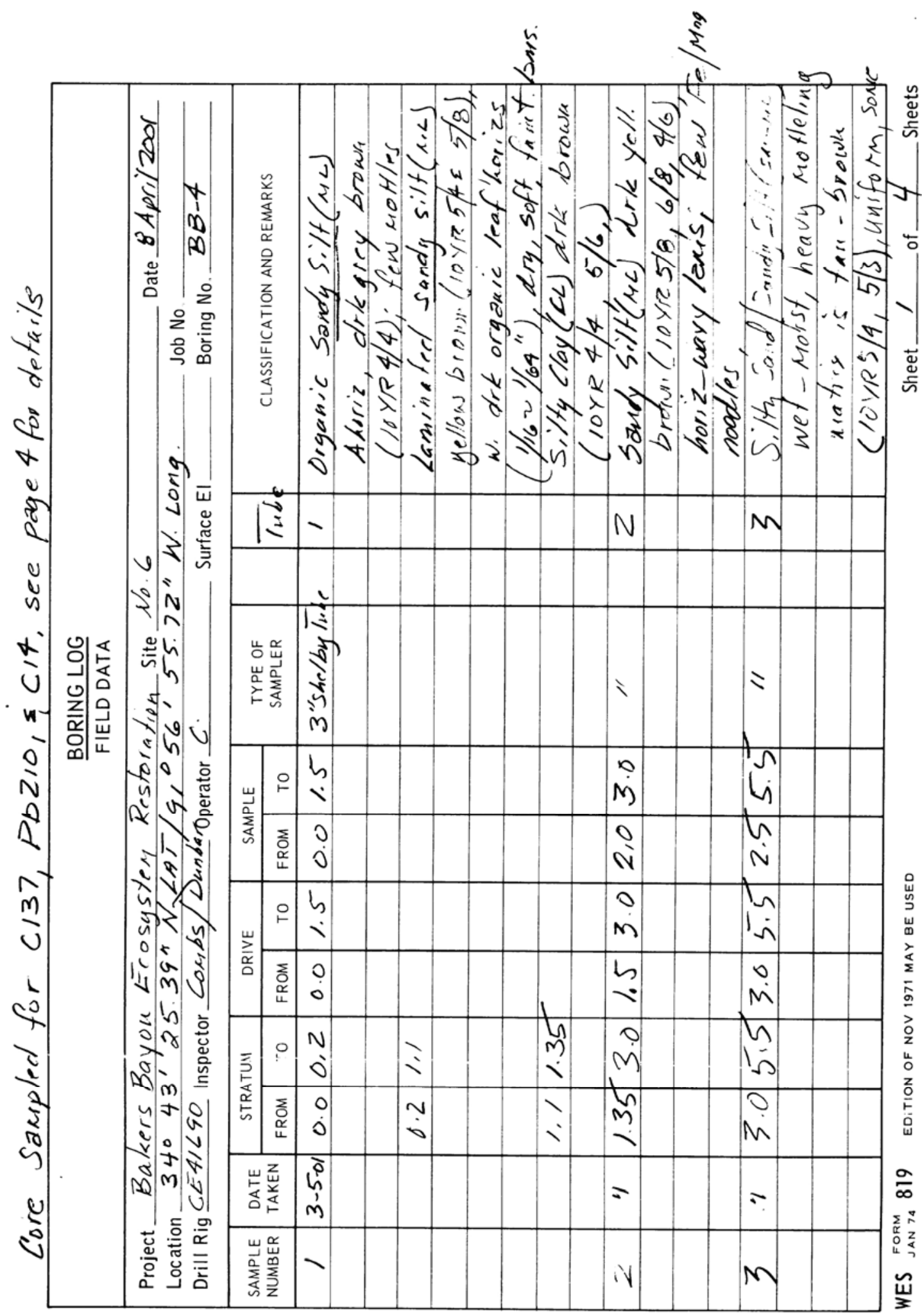




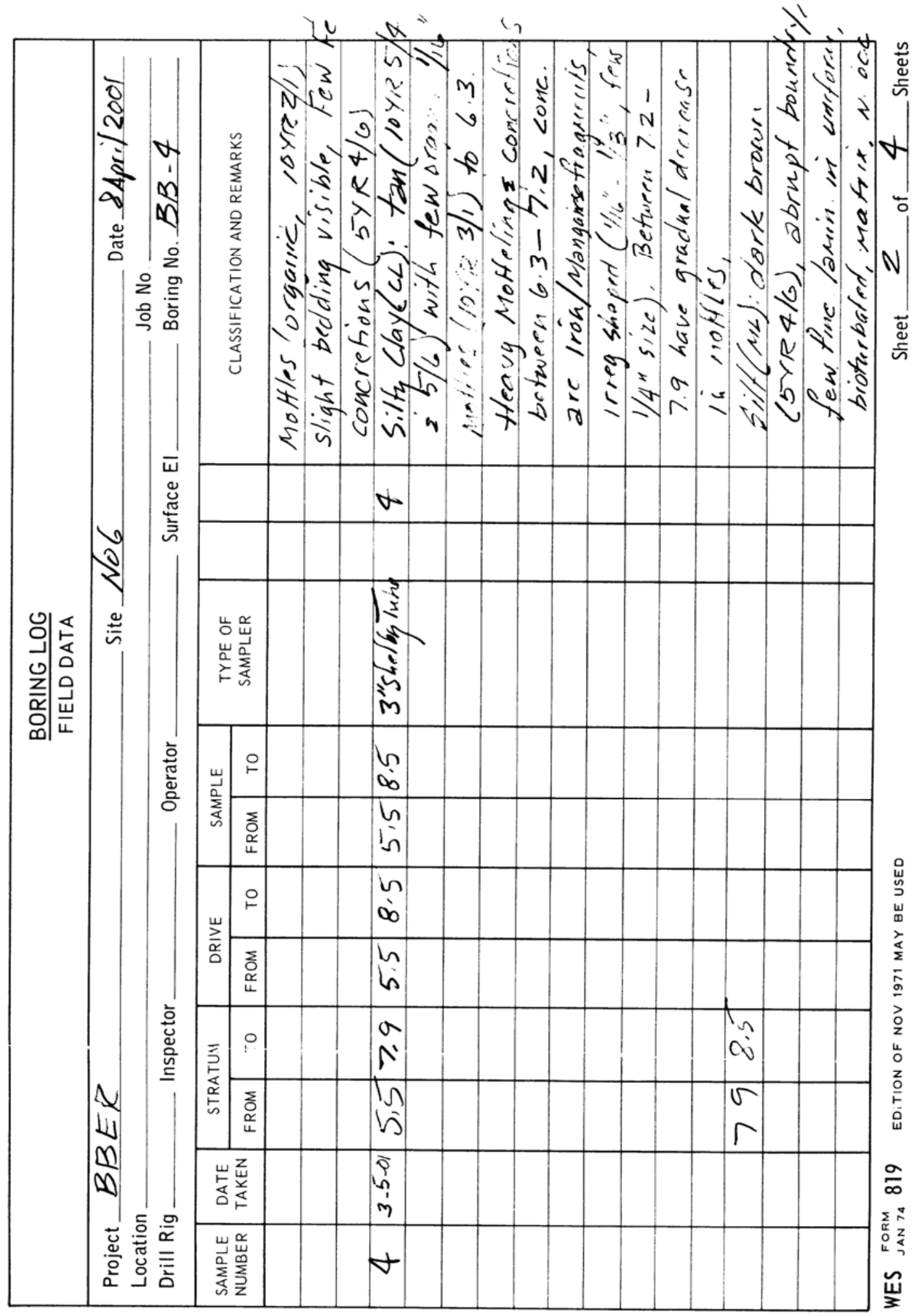




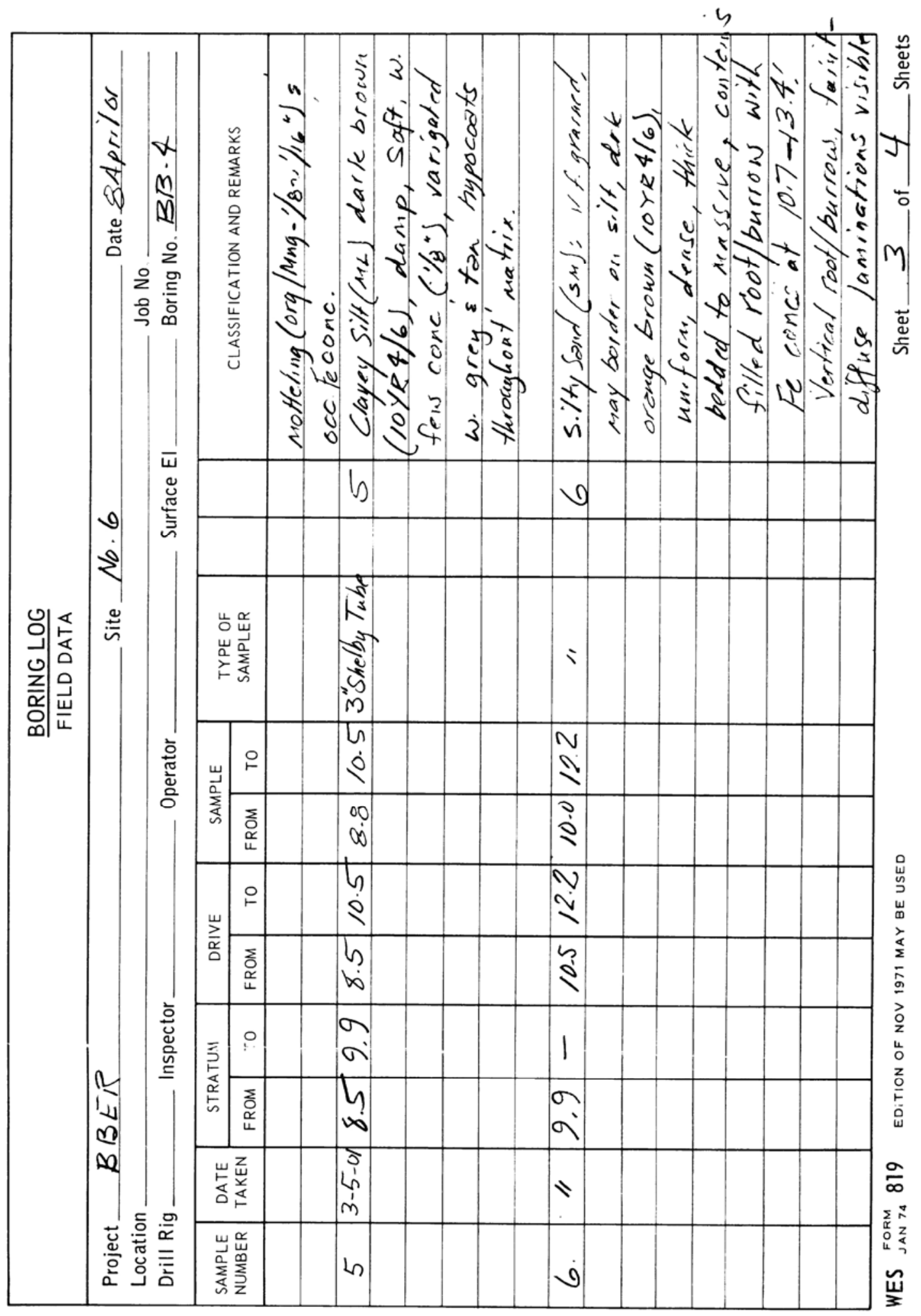




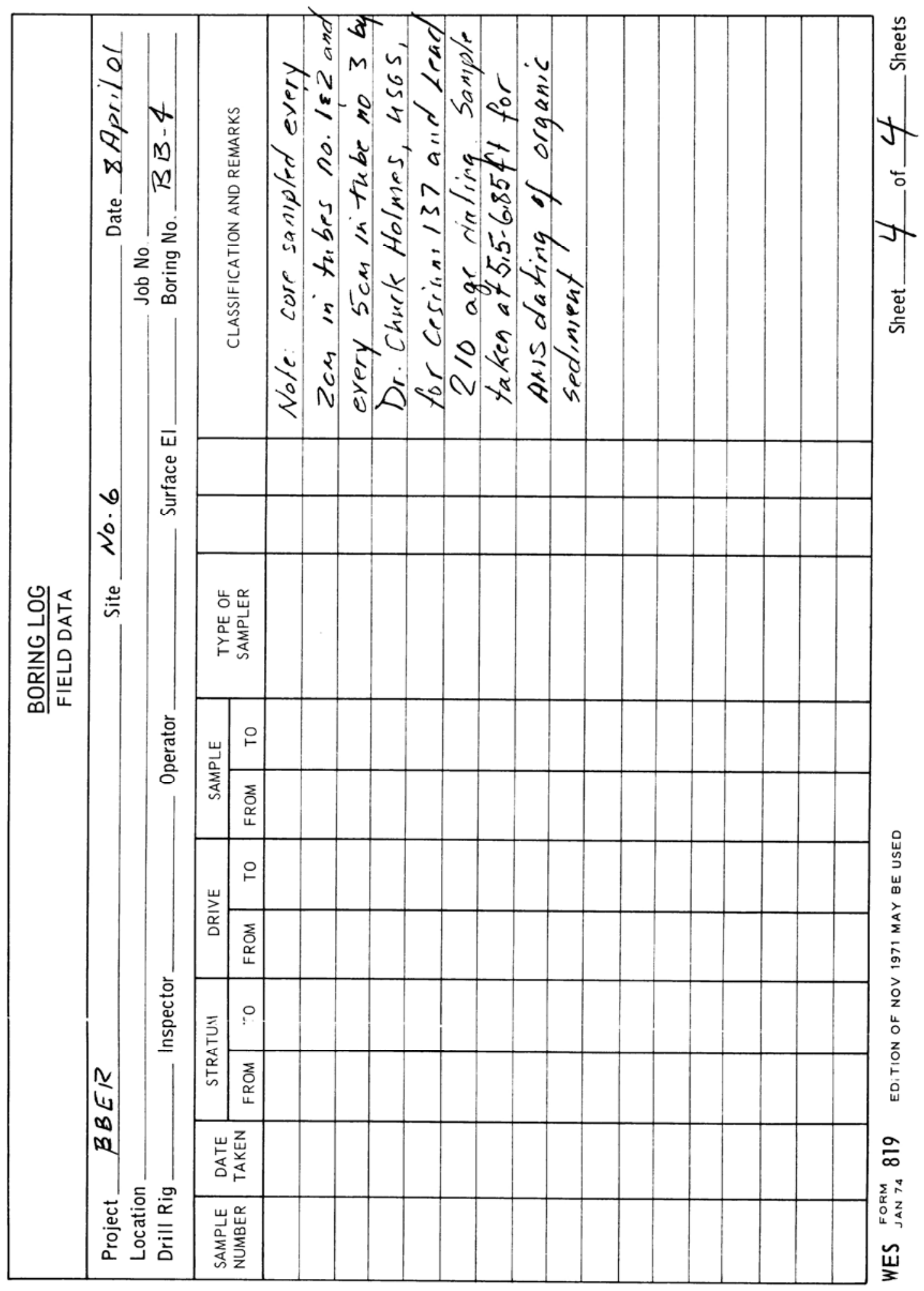




\section{\#4}

FIELD BORING LOG

4 BB Cl-OI

HOLE NO.

SHEET _ OF

PROJECT Bakeis Bayen.

DRILL RIGCFUIGSO F-15CO INSPECTOR LOCATION

DEPTH OF WATER DATE TABLE

DATE ELEVATION OF GROUND

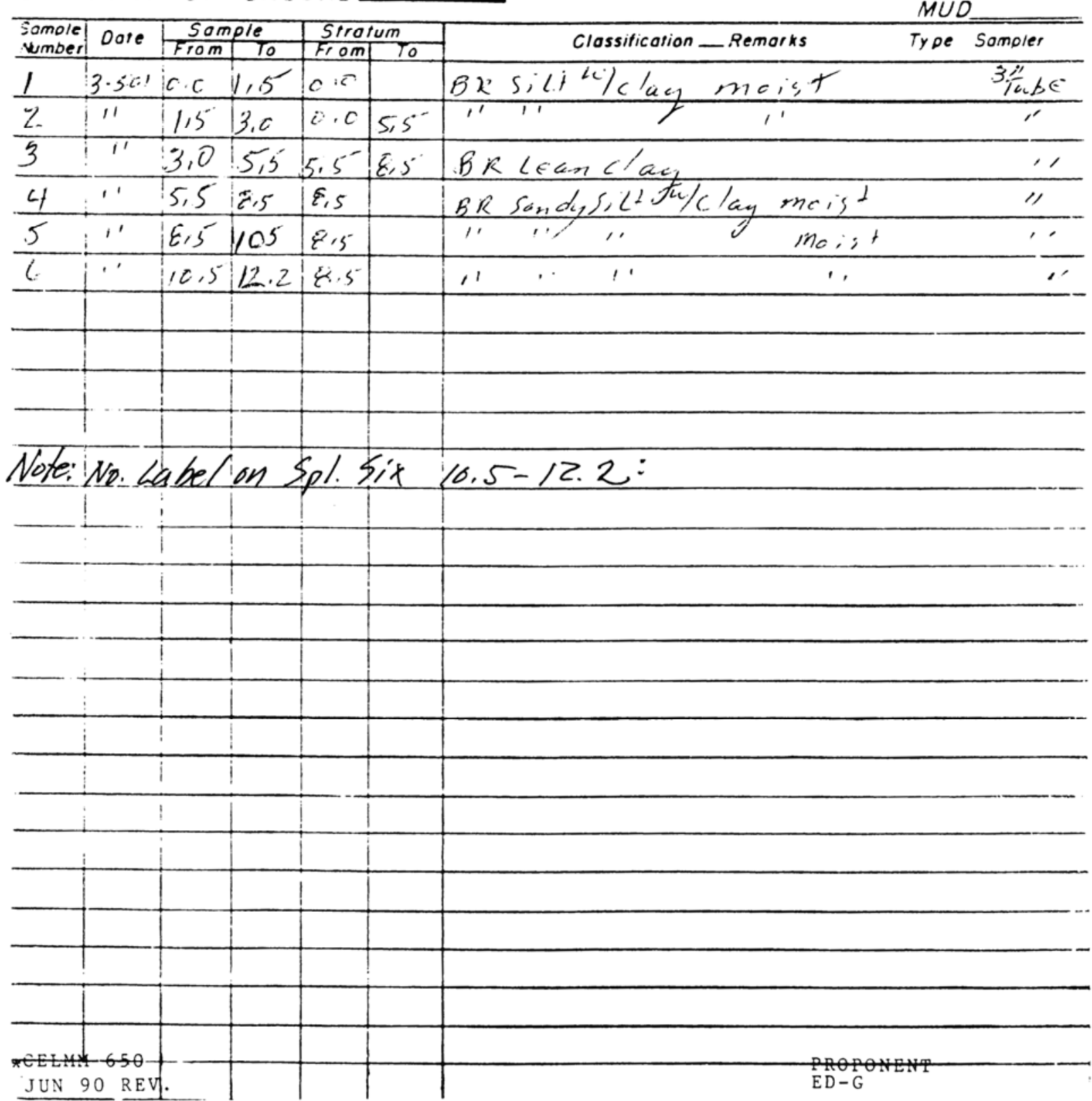




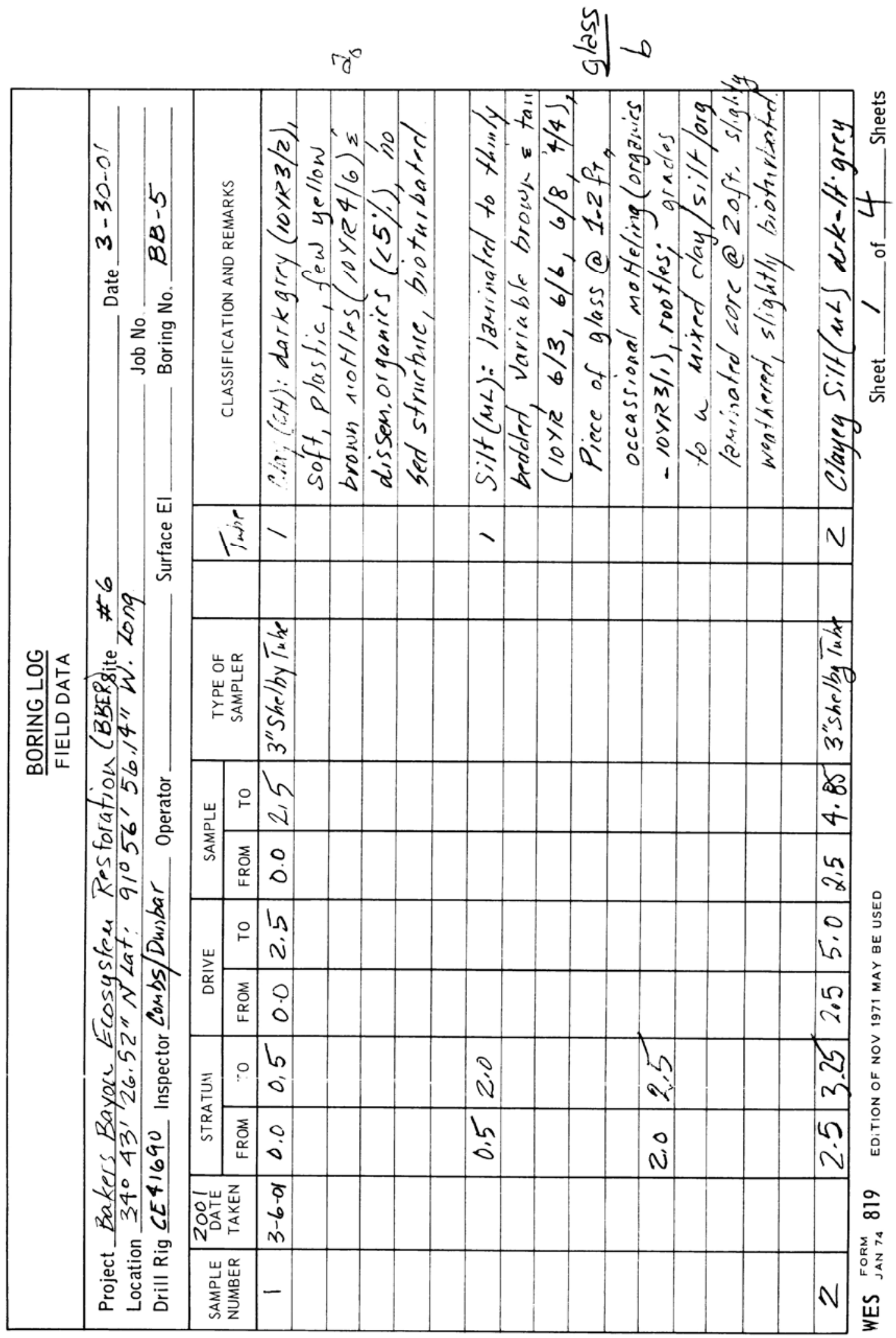




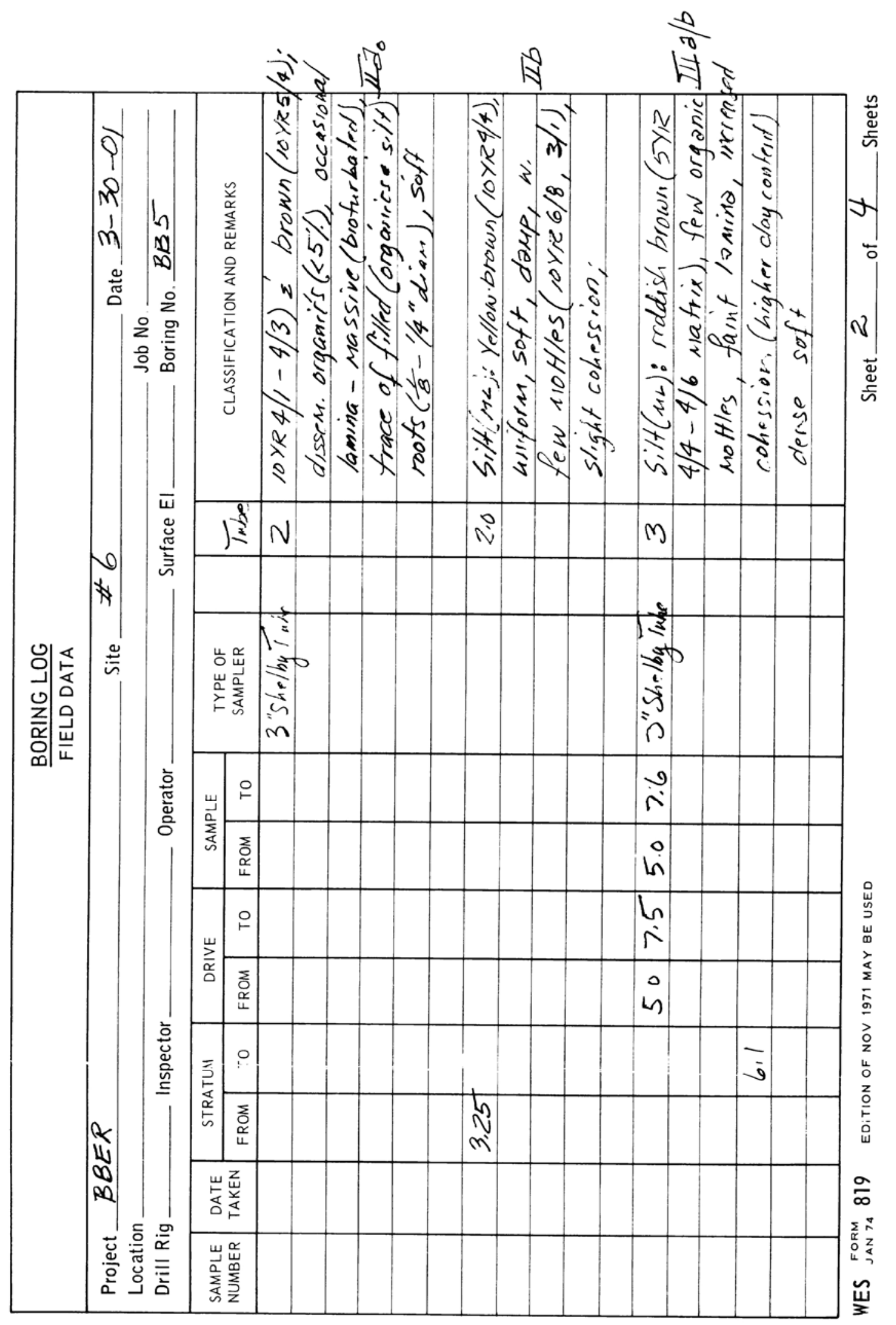




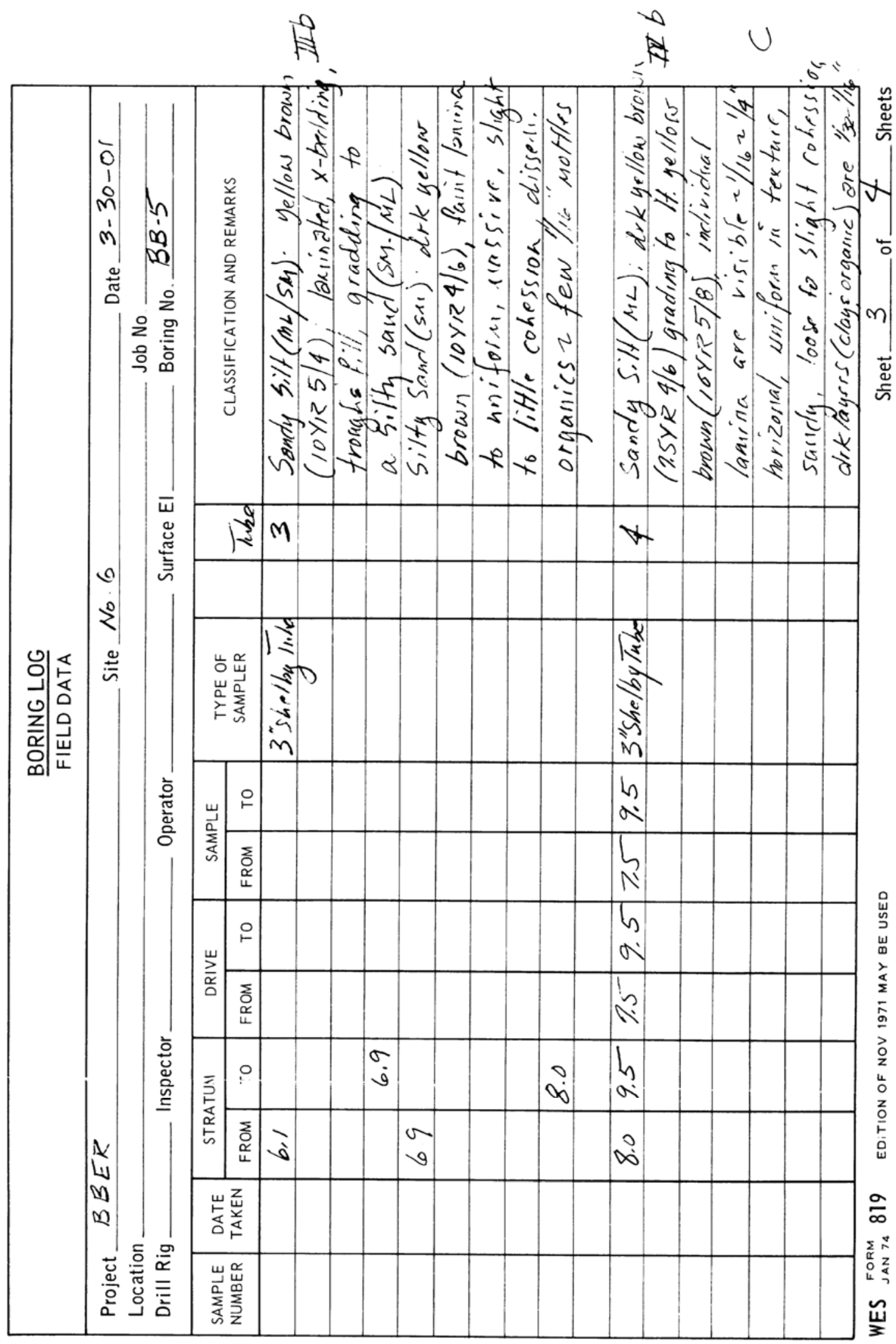




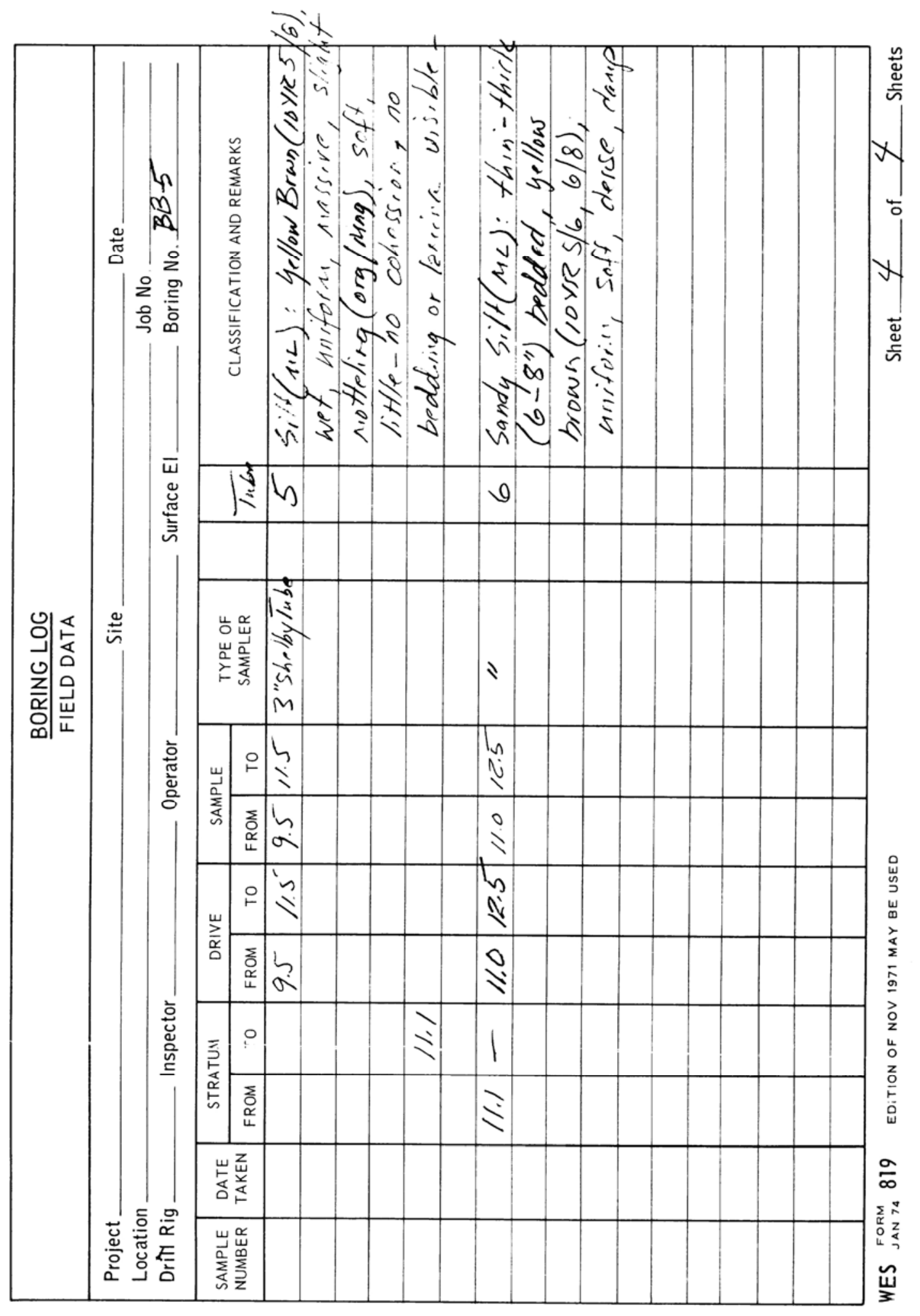




\section{$\# 5$ \\ FIELD BORING LOG \\ 5-BBCLCI \\ HOLE NO. \\ SHEET__ OF}

PROJECTBakers Bayou

DRILL RIG IE 4 It-9O Fli5'0 INSPECTOR Cambs

\section{DEPTH OF WATER —DATE}

TABLE

OPERATORM Main h

ELEVATION OF GROUND

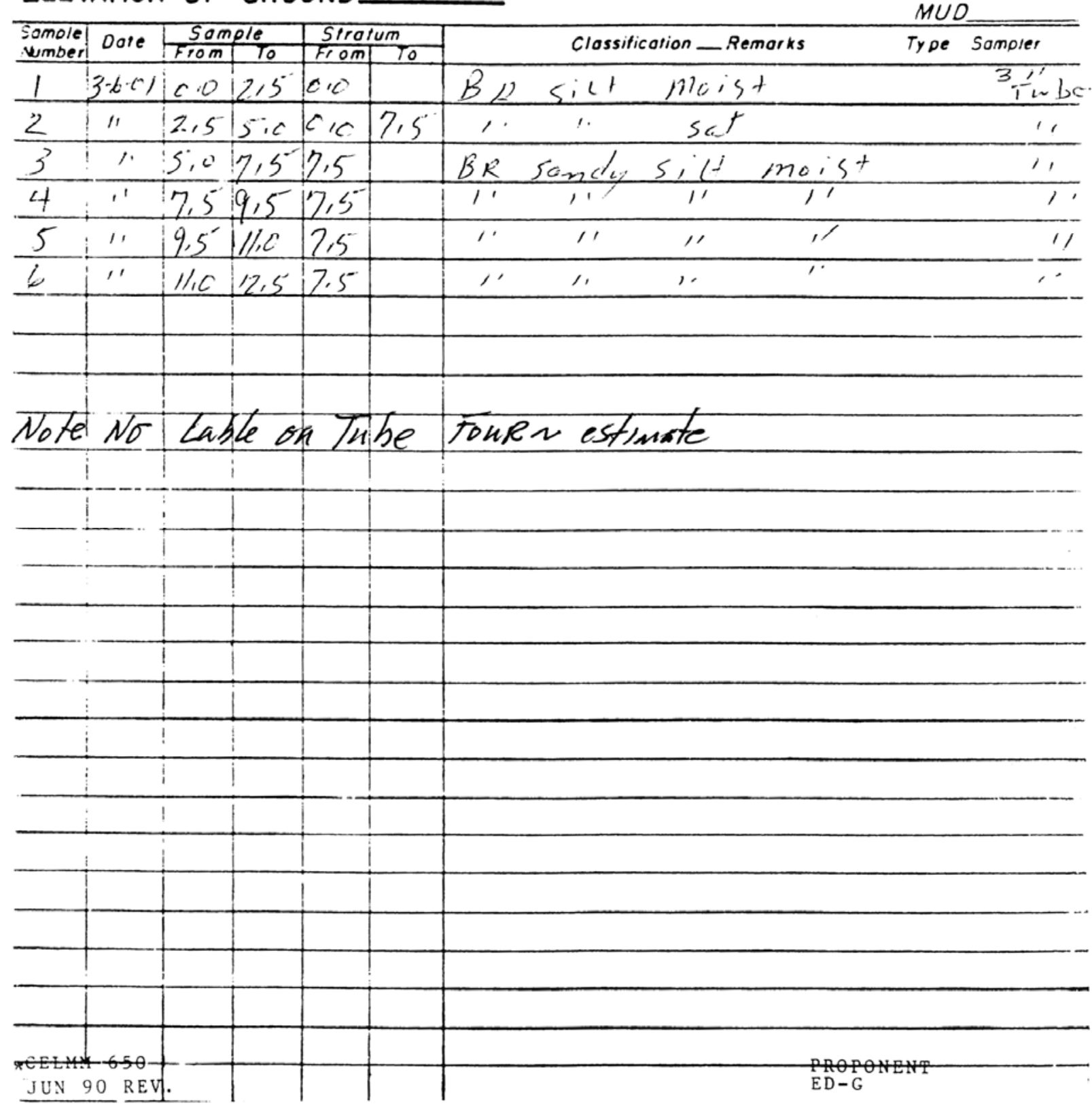




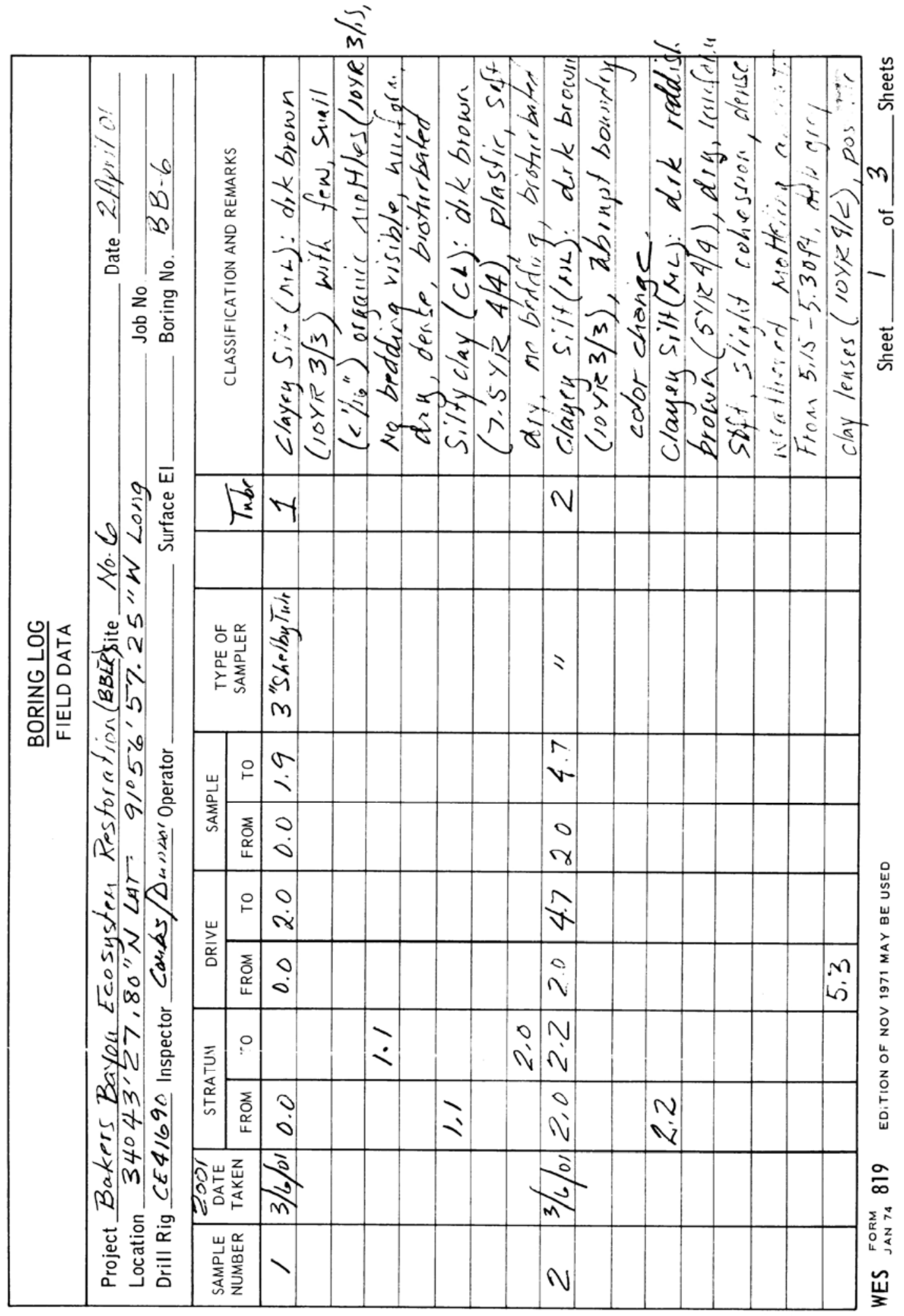




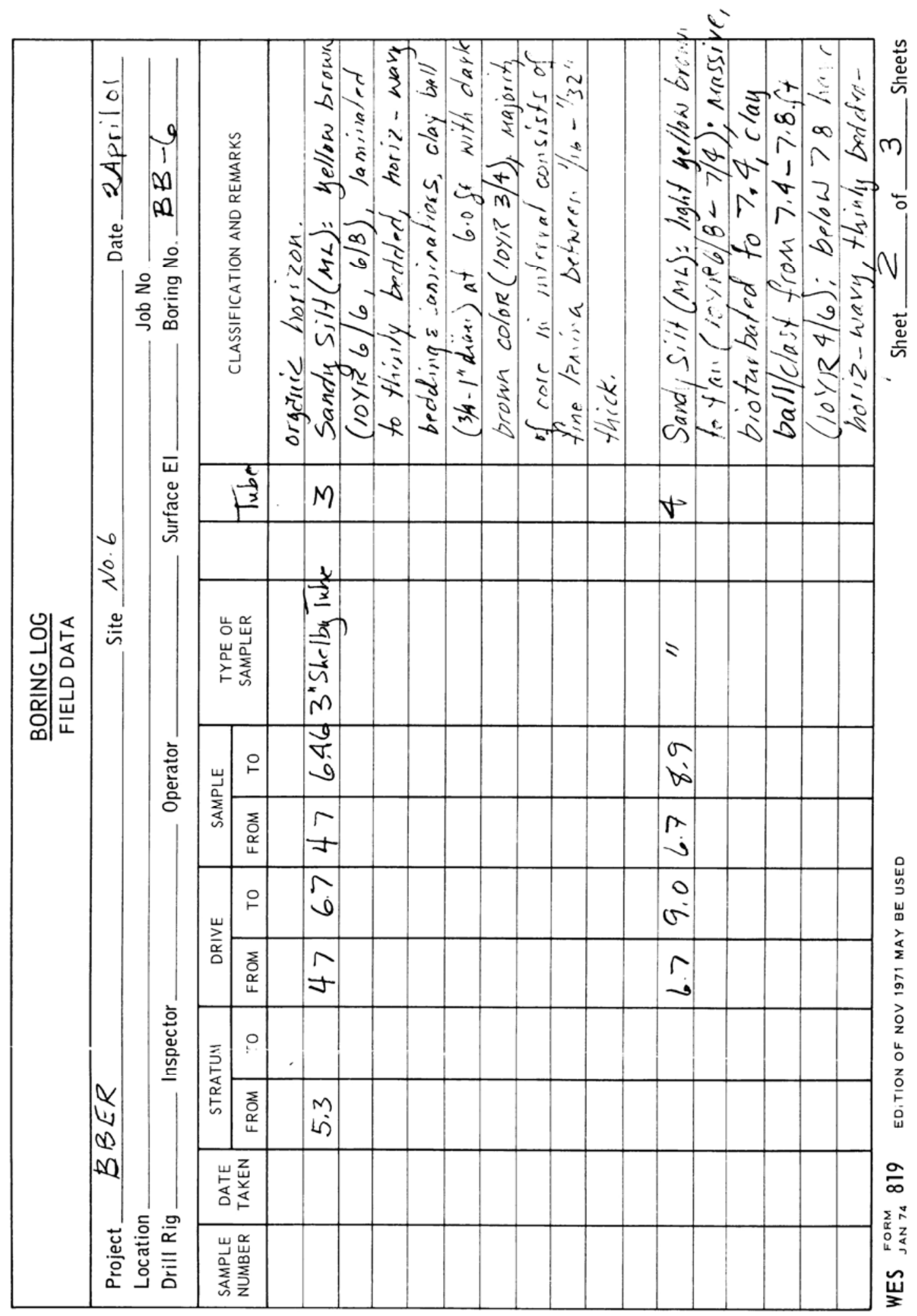




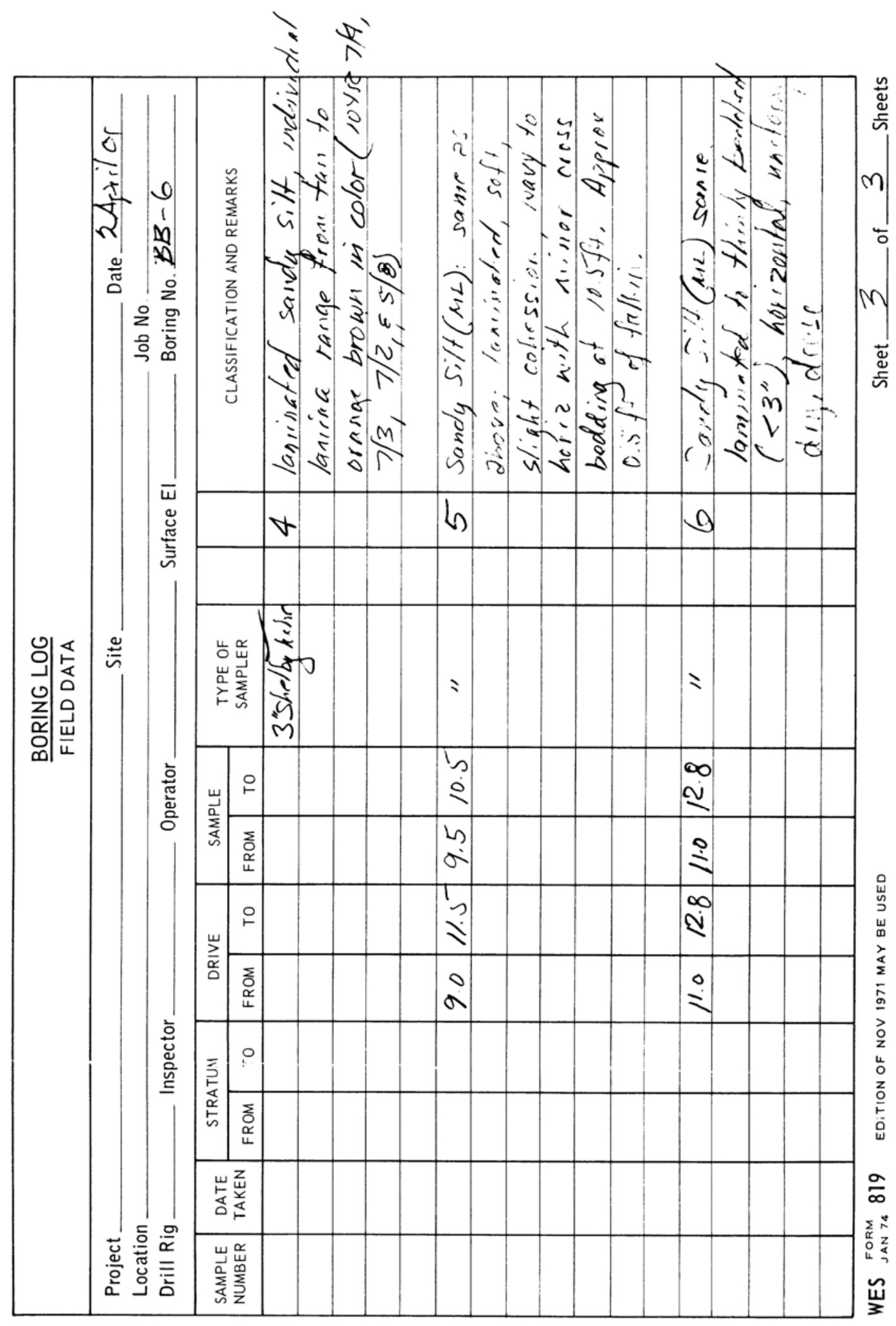




\section{$\# 6$}

FIELD BORING LOG

6. BBCL.CI

HOLE NO

SHEET

PROJECT BaKers Bay oue

LOCATION

DRILL RIGLEYIG9O FISCO INSPECTOR Contes OPERATOR mann.

DEPTH OF WATER DATE TABLE DATE ELEVATION OF GROUND

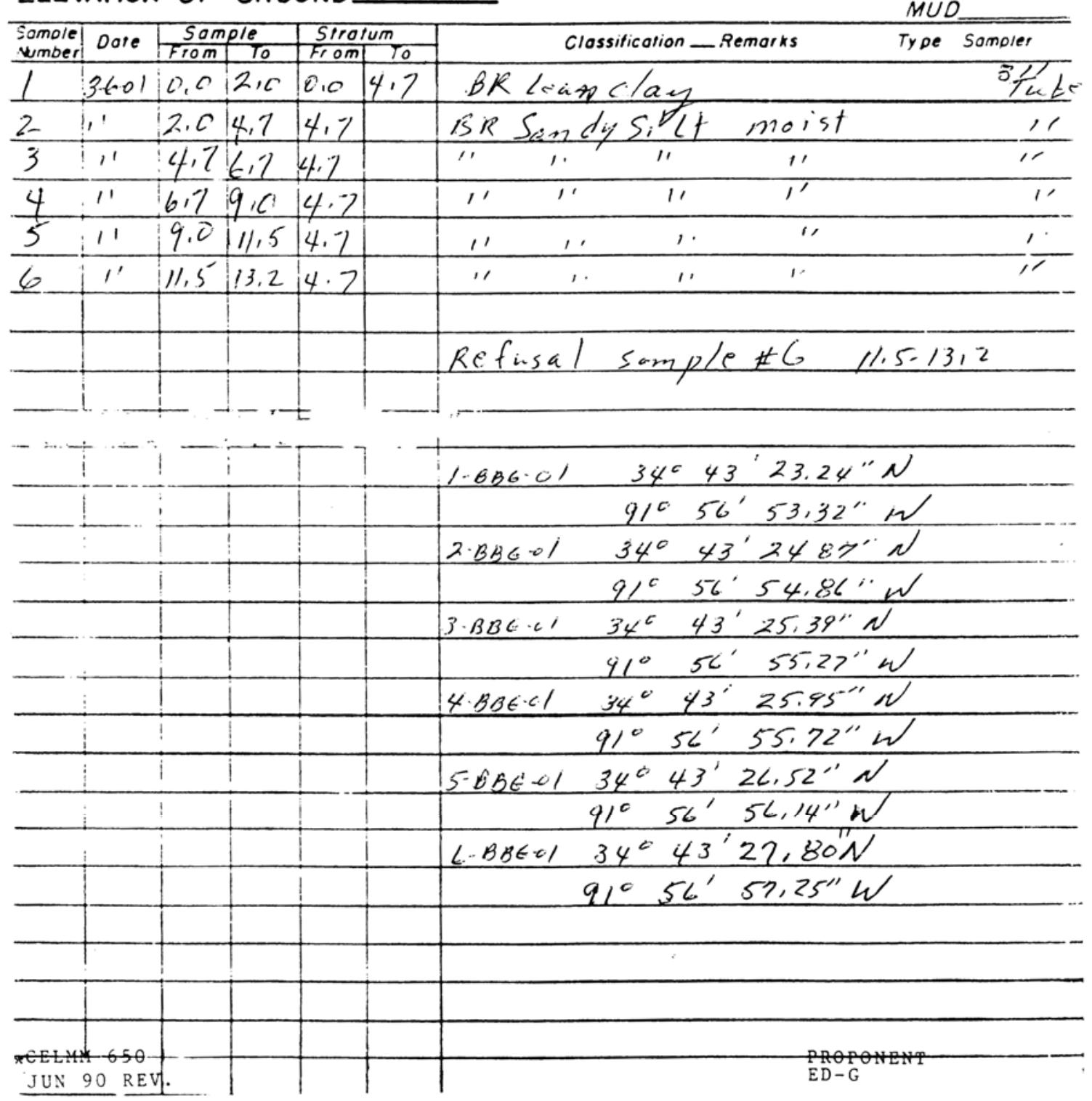




\section{Appendix B \\ Cesium-137 and Lead-210 Dating Results}


Dunbar, Joseph B ERDC-GSL-MS

\begin{tabular}{|c|c|}
\hline $\begin{array}{l}\text { From: } \\
\text { Sent: } \\
\text { To: } \\
\text { Subject: }\end{array}$ & $\begin{array}{l}\text { Charles W Holmes [cholmes@usgs.gov] } \\
\text { Thursday, June 21, 2001 11:36 AM } \\
\text { Dunbar, Joseph B } \\
\text { Bakers bayou }\end{array}$ \\
\hline & 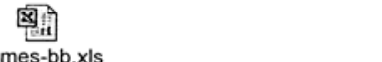 \\
\hline
\end{tabular}

Joe:

The calculated rate of accumulation is $0.09 \mathrm{~cm} / \mathrm{yr}$. This put the $14 \mathrm{~cm}$ interval at about 151 years/pb. The core was very difficult because of the variation in sediment type. But I think we got a good handle on it by separating the coarse from the fined. This is why the sample intervals are different from those I took.

The Attached excel files contains the data and the curve. The $\mathrm{Pb}-210$ in

the raw number, the Ra226 in the radium which is used as the ambient $210 \mathrm{~Pb}$.

As you can see the only Cs-137 that showed up was in the top sample. The

top was duplicated.

Any questions call, I will be in and out for the next two weeks.

Chuck Holmes

600 4th Street South

St. Petersburg, F1 3370

Phone (voice) 727-803-8747 (ex 3056)

Fax 727-803-2032 


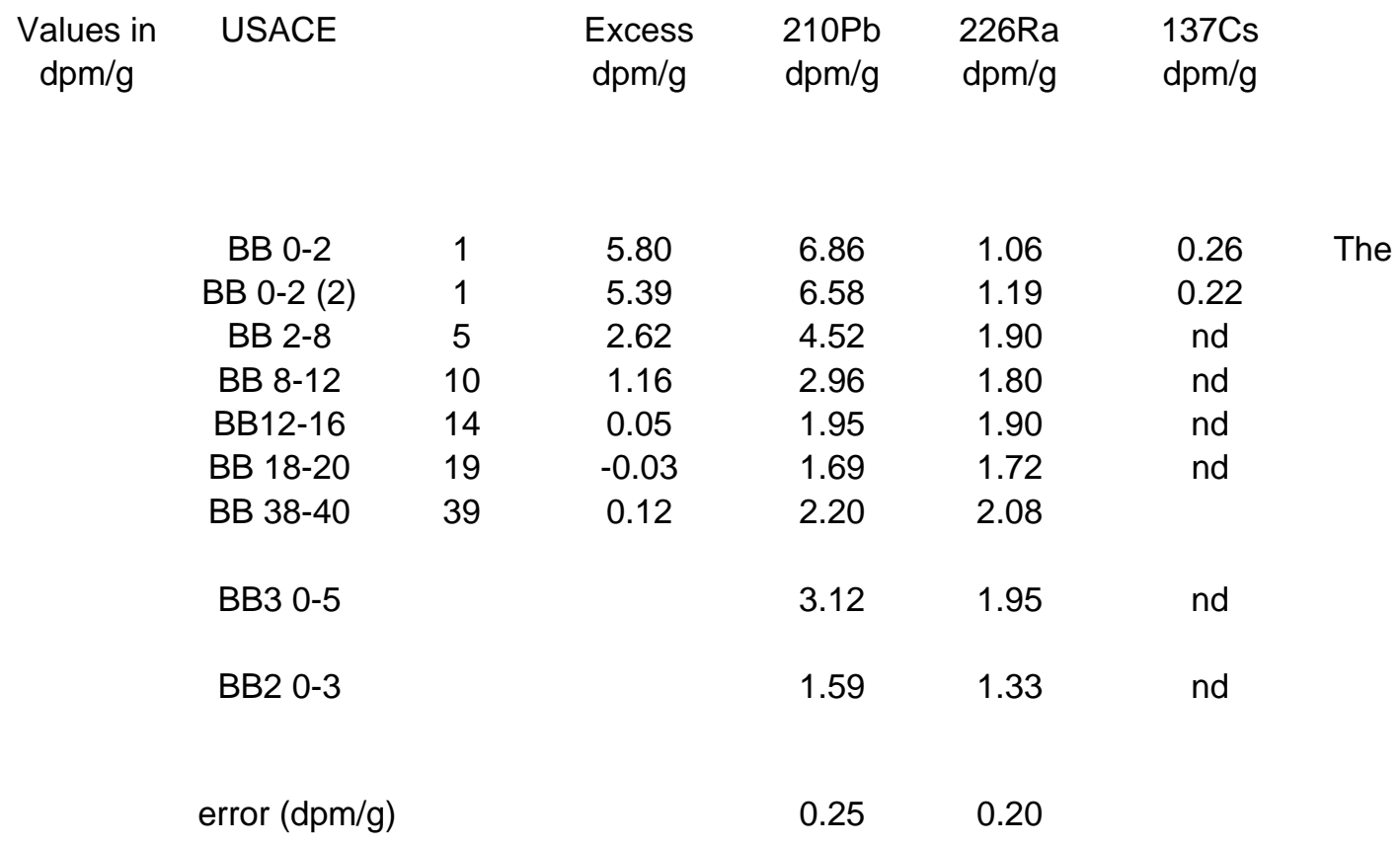

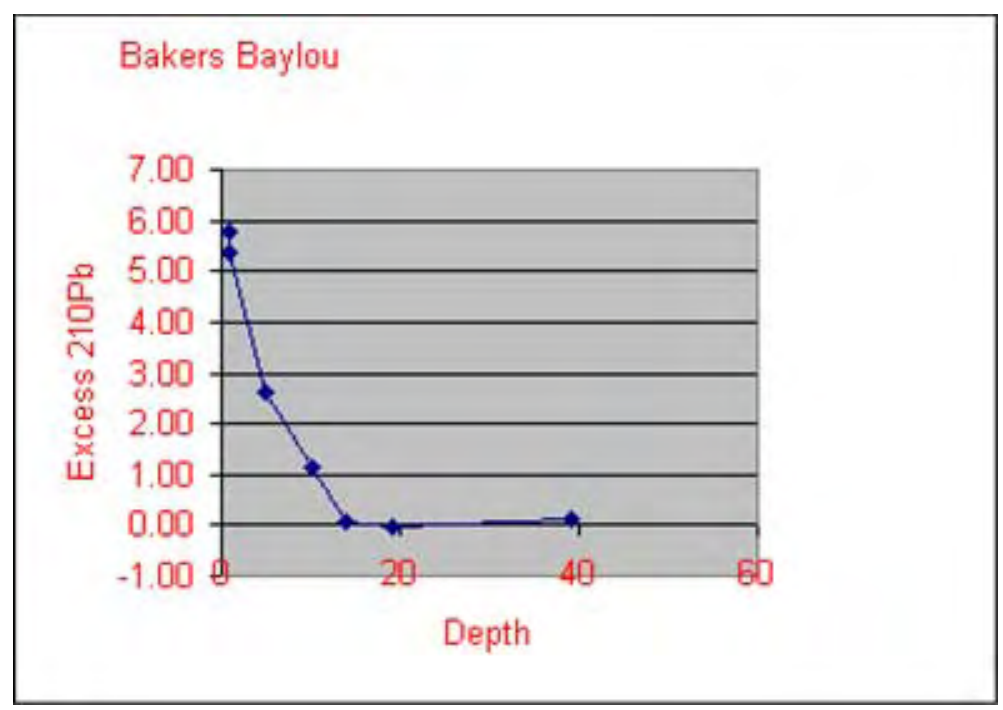




\begin{tabular}{cccr} 
ppm & \multicolumn{2}{c}{$\mathrm{dpm} / \mathrm{g} \quad \mathrm{dpm} / \mathrm{g}$ inaa/gamma } \\
11.7 & 2.8314 & 2.98 & 0.9501342 \\
& & & \\
11.9 & 2.8798 & 3.51 & 0.8204558 \\
& & & \\
11.9 & 2.8798 & 3.28 & 0.8779878 \\
& & & \\
& & & \\
& & & \\
12.8 & 3.0976 & 3.86 & 0.802487 \\
12.4 & 3.0008 & 3.35 & 0.8957612 \\
10.7 & 2.5894 & 3.12 & 0.8299359 \\
11.6 & 2.8072 & 3.08 & 0.9114286 \\
11.8 & 2.8556 & 3.16 & 0.9036709 \\
11.9 & 2.8798 & 3.52 & 0.818125 \\
12.9 & 3.1218 & 3.34 & 0.9346707 \\
12.4 & 3.0008 & 3.41 & 0.88 \\
10.9 & 2.6378 & 3.45 & 0.7645797 \\
12.8 & 3.0976 & 3.29 & 0.9415198
\end{tabular}




\section{Appendix C Carbon-14 Dating Results}


May 25, 2001

Mr. Joseph B. Dunbar

US Army Corps of Engineers

Waterways Experiment Station

CEWES-66Y

3909 Halls Ferry Road

Vicksburg, MS 39180

USA

RE: Radiocarbon Dating Result For Sample BB-4-C14-1@6.85'+6.5+5.5

Dear Mr. Dunbar:

Enclosed is the radiocarbon dating result for one sample recently sent to us. It provided plenty of carbon for an accurate measurement and the analysis went normally. The report sheet contains the method used, material type, applied pretreatments and, where applicable, the two sigma calendar calibration range.

As always, this report has been both mailed and sent electronically. All results (excluding some inappropriate material types) which are less than about 20,000 years BP and more than about $\sim 250$ BP include this calendar calibration page (also digitally available in Windows metafile (.wmf) format upon request). Calibration is calculated using the newest (1998) calibration database with references quoted on the bottom of the page. Multiple probability ranges may appear in some cases, due to short-term variations in the atmospheric 14C contents at certain time periods. Examining the calibration graph will help you understand this phenomenon. Don’t hesitate to contact us if you have questions about calibration.

We analyzed this sample on a sole priority basis. No students or intern researchers who would necessarily be distracted with other obligations and priorities were used in the analysis. We analyzed it with the combined attention of our entire professional staff.

Information pages are also enclosed with the mailed copy of this report. If you have any specific questions about the analysis, please do not hesitate to contact us.

The cost of the analysis was charged to your VISA card. A receipt is enclosed. Thank you. As always, if you have any questions or would like to discuss the results, don't hesitate to contact me.

Sincerely,

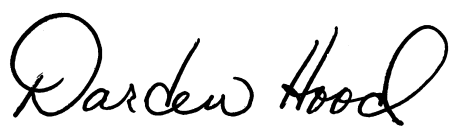




\begin{tabular}{|c|c|c|c|}
\hline Sample Data & $\begin{array}{c}\text { Measured } \\
\text { Radiocarbon Age }\end{array}$ & $\begin{array}{c}\text { 13C/12C } \\
\text { Ratio } \\
\end{array}$ & $\begin{array}{c}\text { Conventional } \\
\text { Radiocarbon Age }(*) \\
\end{array}$ \\
\hline $\begin{array}{l}\text { Beta - } 154710 \\
\text { SAMPLE: BB-4 } \\
\text { ANALYSIS : AN } \\
\text { MATERIAL/PRE } \\
2 \text { SIGMA CALIB }\end{array}$ & $\begin{array}{l}1530+/-40 \text { BP } \\
\text {-1@6.85'+6.5+5.5 } \\
\text { candard delivery } \\
\text { ATMENT : (organ } \\
\text { CION : Cal AD } 42\end{array}$ & $\begin{array}{l}\text { ediment); ac } \\
620 \text { (Cal BH }\end{array}$ & $\begin{array}{l}\text { washes } \\
530 \text { to } 1330 \text { ) }\end{array}$ \\
\hline
\end{tabular}




\section{CALIBRATION OF RADIOCARBON AGE TO CALENDAR YEARS}

(Variables: C 13/C 12=-24.4:lab. mult=1)

Laboratory number: Beta-154710

Conventional radiocarbon age: $1540 \pm 40 B P$

2 Sigma calibrated result: Cal AD 420 to 620 (Cal BP 1530 to 1330)

(95\% probability)

Intercept data

Intercept of radiocarbon age

with calibration curve:

$1 \mathrm{~S}$ igm a calibrated result:

(68\% probability)

Cal A D 540 (Cal B P 1410)

Cal AD 450 to 570 (Cal B P 1500 to 1380)

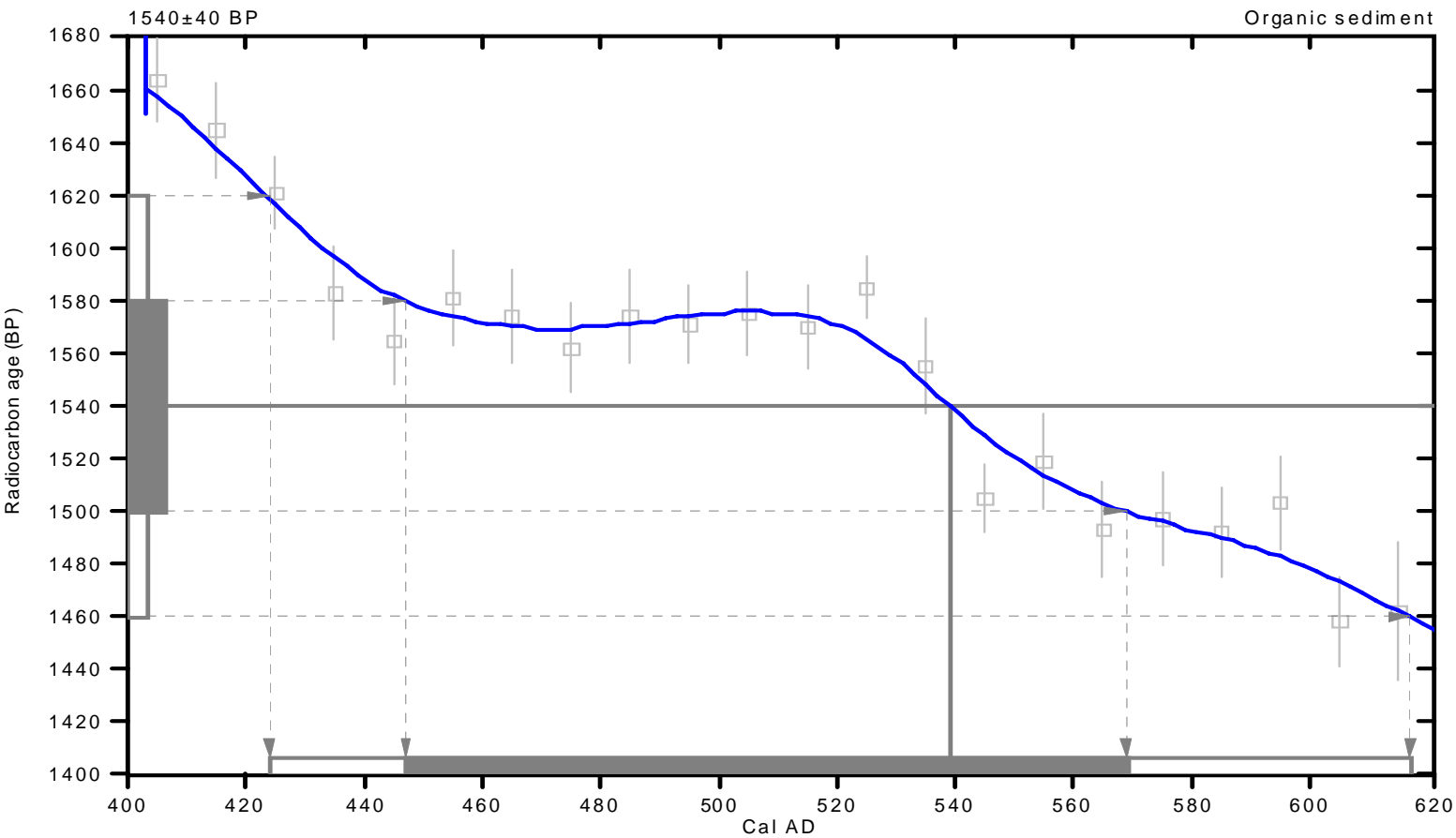

References:

Database used

Calibration Database

Editorial Com ment

Stuiver, M., van der Plicht, H., 1998, Radiocarbon 40(3), pxi i-xiii

IN TCAL 98 Radiocarbon Age Calibration

Stuiver, M., et. al., 1998, Radiocarbon 40(3), p1041-1083

Mathematics

A Simplified Approach to Calibrating C14 Dates

Talma, A.S., Vogel, J. C., 1993, Radiocarbon 35(2), p317-322

\section{Beta Analytic Inc.}

4985 SW 74 Court, Miami, Florida 33155 USA・Tel: (305)6675167•Fax: (305)6630964・E-Mail: beta@ radiocarbon.com 


\section{Appendix D Topographic Profiles Across Bakers Bayou}




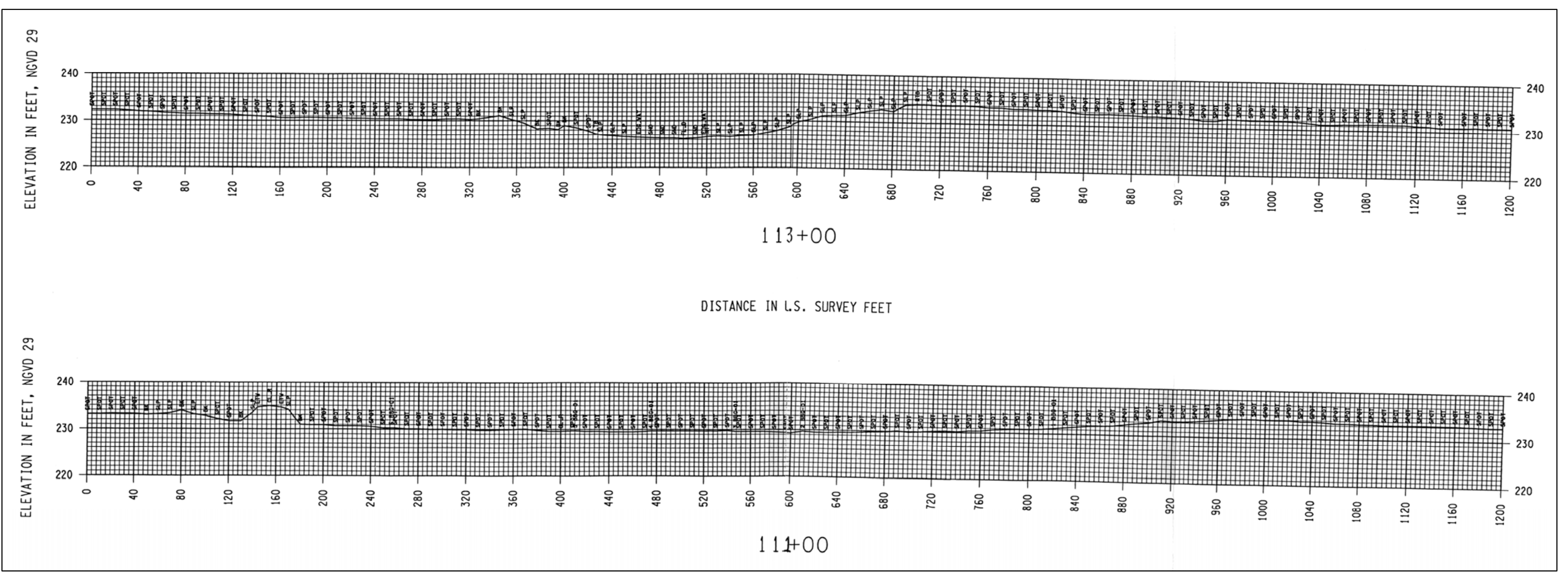




\section{Appendix E USDA Soil Profile Information}

Typical pedon of Keo silt loam, 0 to 1 percent slopes, in a field in the NE1/4NE1/4SW1/4 sec. 21, T. 1 N., R. 10 W., Lonoke County:

Ap-0 to 6 inches; dark brown (7.5YR 4/4) silt loam; weak fine granular structure; very friable; common fine roots; slightly acid; abrupt smooth boundary.

B1-6 to 12 inches; dark brown (7.5YR 4/4) silt loam; weak medium subangular blocky structure; very friable; few fine roots; slightly acid; clear smooth boundary.

B2-12 to 30 inches; dark brown (7.5YR 4/4) silt loam; weak medium subangular blocky structure; friable; common fine pores; neutral; clear wavy boundary.

C1-30 to 48 inches; brown (7.5YR 4/4) very fine sandy loam; massive; very friable; neutral; clear smooth boundary.

IIAb-48 to 54 inches; dark brown (7.5YR 4/4) silt loam; few fine distinct strong brown mottles; weak medium subangular blocky structure; friable, few fine pores; few dark stains; few small concretions; mildly alkaline; clear smooth boundary.

IIIC2-54 to 72 inches; brown (7.5YR 5/4) very fine sandy loam; massive; very friable; mildly alkaline.

Typical pedon of Perry silty clay, 0 to 1 percent slopes, in a field in the NE1/4NE1/4SW1/4 sec. 24, T. 2 S., R. 8 W., Lonoke County:

Ap-0 to 4 inches; dark gray (10YR 4/1) silty clay; few fine distinct strong brown mottles; weak medium subangular blocky structure; firm; common fine roots; medium acid; abrupt smooth boundary.

B21g-4 to 23 inches; gray (10YR 5/1) clay; common medium distinct strong brown (7.5YR 5/6) mottles; moderate medium subangular 
blocky structure; very firm; few fine roots; few slickensides which do not intersect; few black stains; medium acid; clear smooth boundary.

B22g - 23 to 34 inches; dark gray (10YR 4/1) clay; few fine distinct strong brown and reddish brown mottles; moderate medium subangular blocky structure; very firm; few fine roots; few slickensides which do not intersect; slightly acid; clear wavy boundary.

IIB3-34 to 54 inches; reddish brown (5YR 4/3) clay; common fine faint dark reddish gray mottles; moderate medium subangular blocky structure; very firm; few slickensides which do not intersect; common carbonate concretions; mildly alkaline; gradual wavy boundary.

IIC—54 to 72 inches; reddish brown (5YR 4/3) silty clay; common medium faint dark reddish gray (5YR 4/2) and distinct yellowish red (5YR 4/6) mottles; weak medium subangular blocky structure; very firm; common carbonate concretions; calcareous; moderately alkaline.

Typical pedon of Herbert silt loam, 0 to 1 percent slopes, in a field in the SW1/4SE1/4NW1/4 sec. 5, T. 2 S., R. 9 W., Lonoke County:

Ap-0 to 7 inches; brown (10YR 4/3) silt loam; weak medium granular structure; friable; common fine and medium roots; few fine pores; strongly acid; clear smooth boundary.

A2-7 to 14 inches; grayish brown (10YR 5/2) silt loam; common medium distinct brown (10YR 4/3) and strong brown (7.5YR 5/6) mottles; weak medium subangular blocky structure; friable; few fine roots; common fine pores; few fine dark concretions; strongly acid; clear wavy boundary.

B21t-14 to 27 inches; reddish brown (5YR 4/4) silty clay loam; grayish brown (10YR 5/2) and light brownish gray (10YR 6/2) silt coatings on peds; common medium distinct yellowish red (5YR 5/6) and reddish gray (5YR 5/2) mottles; moderate coarse prismatic parting to moderate medium subangular block structure; firm; thin patchy clay films on faces of peds and in pores; few fine roots; common fine pores; few fine dark concretions; very strongly acid; gradual wavy boundary.

B22t - 27 to 36 inches; reddish brown (5YR 5/4) silt loam; grayish brown (10YR 5/2) and light brownish gray (10YR 6/2) silt coatings on peds; common fine distinct yellowish red and reddish gray mottles; weak coarse prismatic structure parting to moderate medium subangular blocky; thin patchy clay films on faces of peds and in pores; common fine pores; few fine soft dark brown concretions; very strongly acid; gradual wavy boundary.

B3-36 to 53 inches; brown (7.5YR 4/4) silt load; common fine distinct grayish brown and strong brown mottles; weak medium subangular 
blocky structure; friable; few line pores; few fine soft dark brown concretions; strongly acid; gradual wavy boundary.

C—53 to 72 inches; reddish brown (5YR 5/4) silt loam; few fine distinct grayish brown and strong brown mottles; massive; friable; few black stains; few fine soft dark brown concretions; slightly acid.

Typical pedon of Rilla silt loam, 0 to 1 percent slopes, in a field in the SE1/4SE1/4NE1/4 sec. 25, T. 1 S., R. 9 W., Lonoke County:

Ap-0 to 6 inches; dark brown (10YR 4/3) silt loam; weak medium granular structure; friable; common fine and medium roots; medium acid; abrupt smooth boundary.

A2-6 to 12 inches; brown (10YR 5/3) silt loam; few fine faint dark yellowish brown mottles; weak medium subangular blocky structure; friable; few fine roots; few fine pores; strongly acid; clear wavy boundary.

B2t-12 to 38 inches; reddish brown (5YR 4/4) silty clay loam; moderate medium and coarse subangular blocky structure; firm; thin pale brown (10YR 6/3) silt coatings on faces of peds; few thin patchy clay films on peds; common fine pores; very strongly acid; gradual wavy boundary.

B3-38 to 55 inches; yellowish red (5YR 4/6) silt loam; weak medium subangular blocky structure; friable; few thin patchy clay films; few fine pores; small pockets and streaks of pale brown loam; very strongly acid; gradual wavy boundary.

C—55 to 72 inches; yellowish red (5YR 4/6) loam; massive; very friable; common pale brown (10YR 6/3) fine sandy loam pockets and streaks; strongly acid. 


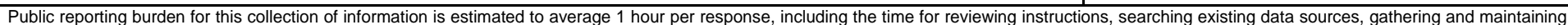

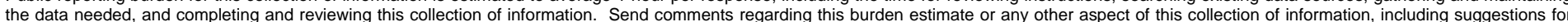

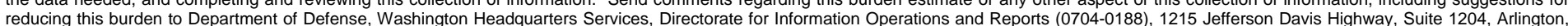

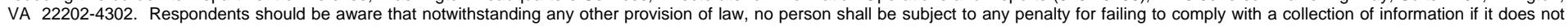
display a currently valid OMB control number. PLEASE DO NOT RETURN YOUR FORM TO THE ABOVE ADDRESS.
1. REPORT DATE (DD-MM-YYYY) May 2005
2. REPORT TYPE
Final report

4. TITLE AND SUBTITLE

Geomorphic Investigation of Bakers Bayou Near Lonoke, Arkansas

\section{AUTHOR(S)}

Joseph B. Dunbar

\section{PERFORMING ORGANIZATION NAME(S) AND ADDRESS(ES)}

Geotechnical and Structures Laboratory, U.S. Army Engineer Research and Development Center, 3909 Halls Ferry Road, Vicksburg, MS 39180-6199

3. DATES COVERED (From - To)

5a. CONTRACT NUMBER

5b. GRANT NUMBER

5c. PROGRAM ELEMENT NUMBER

5d. PROJECT NUMBER

5e. TASK NUMBER

5f. WORK UNIT NUMBER

8. PERFORMING ORGANIZATION REPORT NUMBER

ERDC/GSL TR-05-12

10. SPONSOR/MONITOR'S ACRONYM(S)

11. SPONSOR/MONITOR'S REPORT NUMBER(S)

12. DISTRIBUTION / AVAILABILITY STATEMENT

Approved for public release; distribution is unlimited.

\section{SUPPLEMENTARY NOTES}

\section{ABSTRACT}

This report documents a geomorphic study of a 5-km reach of Bakers Bayou, near Lonoke, AR. The purpose of the study was to determine the historic limits of the channel fill and the width of the prehistoric bayou, a former Arkansas River course. An integrated study was conducted involving historic data, geomorphology, soil stratigraphy, geophysics, and radiometric dating methods. Results of the study indicate that the area evaluated was an active Arkansas River course between 6,000 and 8,000 years before the present, and the maximum channel width was between 600 and $900 \mathrm{ft}$. The channel by 1850 at the area studied was between 66 and $231 \mathrm{ft}$ wide and was tree filled with shallow standing water and no clear-cut main channel.

\section{SUBJECT TERMS}

Arkansas River course

Bakers Bayou

16. SECURITY CLASSIFICATION OF:

a. REPORT

UNCLASSIFIED
Ecosystem restoration

Geomorphology Holocene floodplain

\section{U.S. Army Engineer District, Memphis}

Memphis, TN 38103-1894 